\title{
Heterogeneity in Convergence Rates and Income Determination across U.S. States: Evidence from County-Level Data*
}

\author{
Andrew T. Young ** \\ Department of Economics \\ Emory University \\ Atlanta, GA 30322-2240 \\ Atyoung@emory.edu \\ 404-727-1022 \\ Matthew J. Higgins \\ Department of Economics \\ Emory University \\ Atlanta, GA 30322 \\ Matthew_Higgins@bus.emory.edu \\ 404-385-1389 \\ Daniel Levy \\ Department of Economics \\ Bar-Ilan University \\ Ramat Gan 52900, ISRAEL \\ Levyda@mail.biu.ac.il \\ 972-3-531-8331
}

JEL Codes: O40, O11, O18, R11

21 December 2003

\footnotetext{
* We thank Jordan Rappaport for kindly sharing with us some of his data which was incorporated into this project. The second author gratefully acknowledges financial assistance from a National Science Foundation IGERT Fellowship. All remaining errors are our own.

${ }^{* *}$ Corresponding author.
} 


\title{
Heterogeneity in Convergence Rates and Income Determination across U.S. States: Evidence from County-Level Data
}

\begin{abstract}
We utilize county-level data to explore growth determination in the U.S. and possible heterogeneity in growth determination across individual states. The data includes over 3,000 cross-sectional observations and 39 demographic control variables. We use a consistent two stage least squares estimation procedure. (We report OLS estimates as well.) The estimated convergence rate across the U.S. is about 7 percent per year higher than the 2 percent normally found with OLS in cross-country, U.S. state, and European region samples. Estimated convergence rates for 32 individual states are above 2 percent with an average of 8.1 percent. For 29 states the convergence rate is above 2 percent with 95 percent confidence. For seven states the convergence rate can be rejected as identical to at least one other state's convergence rate with 95 percent confidence. In examining the determinants of balanced growth path heights, we find that government at all levels of decentralization is negatively correlated with economic growth. Educational attainment of a population has a non-linear relationship with economic growth according to our estimates: growth is positively related to high-school degree attainment, seemingly unrelated to obtaining some college education, and then positively related to four-year degree or more attainment. Also, finance, insurance and real estate industry and entertainment industry are positively correlated with growth, while education industry is negatively correlated with growth. Heterogeneity in the effects of balanced growth path determinants across individual states is much harder to detect (or dismiss) than in convergence rates.
\end{abstract}




\section{Introduction}

"Economies converge at a speed of about two percent per year." This is what Sala-i-Martin (1996, p. 1326) put forth as a "mnemonic rule" of economic growth empirics. He was referring to how quickly an economy will converge to its individual balanced growth path for per capita income. Results in line with this rule were first reported by Barro and Sala-i-Martin $(1991,1992)$ and Mankiw, Romer and Weil (1992). ${ }^{1}$ Sala-i-Martin declared two percent a mnemonic rule because the result is found whether a researcher considers samples of countries, U.S. states, or European regions.

However, when any of these samples are used in growth regressions, researchers are implicitly imposing the assumption that all economies have identical growth processes and, therefore, it is meaningful to estimate a single rate of convergence. Evans (1998) and Brock and Durlauf (2001) have emphasized that this assumption is not plausible for most data sets. For example, Evans has noted that, "countries must surely have different technologies, preferences, institutions, market structures, government policies, and so forth"(p.296). These can represent important structural differences.

The primary contribution of this paper is the use of data from 3,058 counties representing the entire U.S. economy to examine heterogeneity in growth processes and convergence rates. This data includes per capita income and 39 demographic variables. The inclusion of these variables in the growth regressions is useful for assessing the empirical relevance of various determinants of balanced growth path positions. Using this data we are able to estimate parameters not only for the U.S., but also for 32 U.S. states as economies in and of themselves. ${ }^{2}$ The many degrees of freedom allow us to identify state-specific convergence and balanced growth path parameters. State by state analysis admits heterogeneity in (i) convergence rates, (ii) balanced growth path affects, and (iii) balanced growth rates (the rate of exogenous technical progress). The heterogeneity (or homogeneity) of the within-state growth processes is explored along dimensions (i) and (ii) in this paper.

\footnotetext{
${ }^{1}$ Quah (1997) and Sala-i-Martin (1996) surveyed some of the literature that followed these seminal studies and explored possible explanations to the uniform $2 \%$ convergence findings. For a more recent survey, see Brock and Durlauf (2001).

${ }^{2}$ The remaining states did not have enough counties for growth equations to be identified.
} 
Evidence of heterogeneity in the structure of growth processes has been reported previously by Durlauf and Johnson (1995) and Lee, Pesaran and Smith (1997). Durlauf and Johnson (1995) examined data from 121 countries and rejected the single linear growth model in favor of a multiple regime alternative using regression tree analysis. Lee et al (1997) showed that deriving a growth equation from an explicitly stochastic Solow (1956) model reveals heterogeneity of balanced growth rates as a source of bias in convergence rate estimates. ${ }^{3}$ Using a panel of 102 countries they found that heterogeneity produces an economically significant downward bias in convergence rate estimates.

Heterogeneity in growth processes has also been the focus of a literature examining the so-called "club convergence" hypothesis that nations are segregated into "clubs" according to important structural similarities and similar initial conditions. Convergence occurs within these clubs only. This hypothesis was borne of Quah's (1996, 1997) identification of an "emerging twin peaks" in the cross-sectional distribution of per capita incomes of 105 countries. Desdoigts (1999) used a nonparametric technique called exploratory projection pursuit (EPP) to determine which of a large number of economic variables cause clustering of economies into clubs. He found that, "[i]nstitutional (OECD versus non-OECD), cultural (Protestant versus Catholic), and geographical (continental) clubs of economies form endogenously on the basis of their economic structure"(p.323). The initial stocks of human capital, per capita income and technology were identified as the primary determinants of the emergent structure. Using a Bayesian variant of break point analysis, Canova (1999) also found evidence that initial conditions lead to clubs. ${ }^{4}$

The above studies of heterogeneity in growth processes are important contributions which this paper builds upon. Durlauf and Johnson's (1995) analysis was non-parametric and identified subsets of countries appearing to have markedly different production functions in the sense that "more developed countries have higher outputlabour ratios than implied by their capital-labour ratios alone"(p.366). They concluded

\footnotetext{
${ }^{3}$ The standard growth equation is derived from the deterministic Solow model, and then an error term is appended ad hoc.

${ }^{4}$ Canova's (1999) analysis, being Bayesian, posited that the structural parameters of economies in a given club are not identical, but rather that they have the same distribution. Canova notes that, therefore, in principle his analysis allowed for structural heterogeneity intra-clubs as well as inter-clubs.
} 
that "the explanatory power of the Solow model may be enhanced with a theory of aggregate production function differences", but did not identify the determinants of the structural differences. Desdoigts' (1999) approach, similarly, identified differences in the average values of certain economic variables across the discovered clubs without identifying the determinants of the differences. Canova (1999) also identified clubs according to initial income and human capital levels, but not the determinants of the clubs. Lee et al's (1997) regressions only covered 1965-1989 so that the degrees of freedom needed to identify the important causes of structural differences were not available. $^{5}$

The existing studies represent a range of ingenious techniques designed to cope with a limited amount of available observations (in terms of both cross-sectional units and time periods) to make meaningful statements concerning growth process heterogeneity. These papers primarily departed from the convergence literature, typified by Barro and Sala-i-Martin (1991, 1992) and Mankiw et al (1992), by innovating along the lines of econometric specification. The present paper uses new data as its primary innovation.

Besides the large amount of observations and conditioning variables, the countylevel data offer numerous advantages in identifying growth processes. A single institution collects the data, ensuring considerable uniformity of variable definitions. There is no exchange rate variation between the counties and the price variation across counties is smaller than across countries. Also, U.S. counties are characterized by exceptional mobility of resources and factors. ${ }^{6}$ Importantly, counties within a given state represent a sample with geographical homogeneity and a shared state government. To a great extent the states are ready-made "clubs" within which (if anywhere) we would expect convergence to occur. High degrees of freedom allow us to study inter-state heterogeneity, while the intra-state homogeneity gives as much assurance of a correct specification as can realistically be hoped for. Lastly of note is the relative homogeneity of U.S. counties as a whole. If we find economically important heterogeneity of growth

\footnotetext{
${ }^{5}$ Country-specific intercepts were evoked to control for all differences in balanced growth paths.

${ }^{6}$ Many of these virtues are, of course, embodied in state-level data used by, e.g. Barro and Sala-i-Martin (1991) and Evans (1997a). However, state-level data sacrifices the large number of observations that we have. A full 29 of our states have counties numbering more than 50 (the number of U.S. states) each.
} 
processes across states, then surely we can infer that as much, or (more likely) more, heterogeneity exists across countries.

Although we primarily address the question of heterogeneity with richer data, we also utilize a cross-sectional variant of a two stage least squares (2SLS) approach suggested recently by Evans (1997a, 1997b) for estimating growth equations. Evans (1997b) demonstrated that data must satisfy highly implausible conditions for ordinary least squares (OLS) estimators to be consistent. He proposed a 2SLS method that produces consistent estimators. He applied the method to a sample of 85 countries and reported convergence rates of between 8 and 9 percent. Evans (1997a) then adapted the method to panel data and studied both international data and state-level data from the U.S. He estimated rates of convergence of about 6 percent across countries and 16 percent across the U.S. If the bias of OLS estimates has caused underestimation of the speed of convergence, then this has important implications for how we view the plight of laggard economies. E.g., a convergence rate of 2 percent means that economies close the gap between their current position and their balanced growth path in approximately 34 years. However, if the actual convergence rate is 6 percent then the gap is closed in 11 years; if it is 16 percent the gap will be closed in 4 years. In Higgins, Levy and Young (2003) we showed that, for the entire U.S., the 2SLS procedure yielded a convergence rate estimate of just under 7 percent, while OLS yielded an estimate of just above 2 percent (the Sala-i-Martin (1996) mnemonic rule). ${ }^{7}$ Here, as well as in the earlier paper, we report both 2 SLS and conventional OLS estimates.

We find significant heterogeneity across within-state convergence rates. Across the 32 states for which we report results, 2SLS point estimates range from 3.8 percent (California) to 15.6 percent (Louisiana). The 95 percent confidence intervals associated with these estimates are precise enough so that the heterogeneity cannot be dismissed on grounds of uncertainty. Interestingly, using the consistent 2SLS estimation every intrastate convergence rate estimate is above the 2 percent mnemonic rule. Moreover, even the lower bounds of 95 percent confidence intervals only fall below 2 percent in 3 cases: California, Iowa and North Dakota (all 1.8 percent). Despite finding significant

\footnotetext{
${ }^{7}$ In Higgins et al (2003) we reported estimates for metro and non-metro county sub-samples, and for five regional sub-samples, and found significant heterogeneity across those cases.
} 
heterogeneity in convergence rates, we also find the vast majority to be homogenous in that they are higher than the mnemonic rule.

The paper is organized as follows. Section 2 discusses the econometric specification of the neoclassical growth regression and the 2SLS technique we employ. Section 3 decribes the county-level data. Section 4 explores heterogeneity in the conditional convergence rates, and a similar exploration of the findings regarding balanced growth path determinants is in section 5. Section 6 concludes.

\section{Econometric Model and 2SLS Estimation Procedure}

The basic specification used here and in other cross-sectional growth regressions arises from the neoclassical growth model of Ramsey (1928), Solow (1956), Swan (1956), Cass (1965) and Koopmans (1965). ${ }^{8}$ The growth model implies that,

$$
\hat{y}(t)=\hat{y}(0) e^{-B t}+\hat{y}^{*}\left(1-e^{-B t}\right)
$$

where $\hat{y}$ is log of income per effective unit of labor (technology assumed to be labor augmenting), $t$ is the time period ( 0 being the initial time period), and $B$ is a nonlinear function of the economy's discount (average, subjective), population growth, and technological growth rates, as well as preference parameters. $B$ governs the speed of adjustment to the steady state. The $\hat{y}^{*}$ is the economy's steady-state log level of income per effective unit of labor. From (2.1) it follows that the average growth rate of income per unit of labor between dates 0 and $T$ is,

$$
\frac{1}{T}(y(T)-y(0))=z+\left(\frac{1-e^{-B T}}{T}\right)\left(\hat{y}^{*}-\hat{y}(0)\right)
$$

where $z$ is the exogenous rate of technical progress and $B$ represents the responsiveness of the average growth rate to the gap between the steady state of log income per effective unit of labor and the initial value. Since effective units of labor $(L)$ are assumed to equal $L e^{z t}$, we have $\hat{y}(0)=y(0)$.

\footnotetext{
${ }^{8}$ A derivation of the baseline specification from the growth model is provided by Barro and Sala-i-Martin (1992).
} 
From this model, growth regressions are obtained by using OLS to fit crosssectional data on economies $1, \ldots, N$ to the equation,

$$
g_{n}=\alpha+\beta y_{n 0}+\gamma^{\prime} x_{n}+v_{n} .
$$

In (2.3), $g_{n}$ is the average growth rate of per capita income for economy $n$ between years 0 and $T$ [i.e., $\frac{1}{T}(y(T)-y(0))$ ], $\alpha$ is a constant that is a function of $\mathrm{z}, \beta=\left(\frac{1-e^{-B T}}{T}\right), x_{n}$ is a vector of variables that control for cross-economy heterogeneity in determinants of the steady-state, $\hat{y}^{*}, \gamma$ is a vector of coefficients on those variables, and $v_{n}$ is the error term assumed to have zero mean and finite variance.

However, Evans (1997b) showed that OLS estimates will be consistent only when the data satisfy highly implausible conditions. Plausible departures from these conditions can produce large biases. Specifically, Evans demonstrated that unless (i) the dynamical structures of the economies examined have identical, first-order autoregressive representations, (ii) every economy affects every other economy symmetrically, and (iii) the set of conditioning variables controls for all permanent cross-economy differences, the OLS estimators of the speed of convergence are inconsistent. They are biased downwards, underestimating the speed of convergence.

Evans (1997b) proposed a 2SLS instrumental variables approach that consistently estimates the speed of convergence as well as the effects of conditioning variables. We use a cross-section variant of his method. The method consists of two stages. In the first stage we use instrumental variables to estimate the equation,

$$
\Delta g_{n}=\omega+\beta \Delta y_{n 0}+\eta_{n}
$$

where

$$
\Delta g_{n}=\frac{\left(y_{n, T}-y_{n, 0}\right)}{T}-\frac{\left(y_{n, T-1}-y_{n,-1}\right)}{T},
$$


$\Delta y_{n 0}=y_{n 0}-y_{n,-1}, y_{n}$ is the logarithm of per capita income for county $n, \omega$ and $\beta$ are

parameters, and $\eta_{n}$ is the error term. We use the lagged (1969) values of all the

independent variables as instruments, with the exception of Metro Area, Water Area, and Land Area. ${ }^{9}$ Given the sample period we use here, we define,

$$
\Delta g_{n}=\frac{\left(y_{n, 1998}-y_{n, 1970}\right)}{T}-\frac{\left(y_{n, 1997}-y_{n, 1969}\right)}{T}
$$

Next, define $\beta^{*}$ as the estimator obtained from equation (2.4). In the second stage, we take the estimate for $\beta^{*}$, multiply it by $y_{n 0}$ and then subtract the product from $g_{n}$. This yields a variable,

$$
\pi_{n}=g_{n}-\beta^{*} y_{n 0}
$$

which is then regressed (using OLS) on an intercept and the vector of variables, $x_{n}$, that are potential influences on balanced growth path levels. This second-stage regression is of the form,

$$
\pi_{n}=\tau+\not x_{n}+\varepsilon_{n},
$$

where $\tau$ and $\gamma$ are parameters and $\varepsilon_{n}$ is an error term. This regression yields a consistent estimator, $\gamma^{*}$. Also note that $\tau$ is the same, in principle, as the OLS $\alpha$. It is an estimate of the exogenous rate of technical progress, $z$, or the balanced growth rate.

What this two stage procedure essentially does is, in the first stage, differences out any uncontrolled form of heterogeneity from the specification so that an omitted variable bias does not occur ${ }^{10}$ and then, in the second stage, uses the resulting estimate of

\footnotetext{
${ }^{9}$ See the data appendix for details.

${ }^{10}$ The derivation of this equation (see Evans (1997b)) depends on the assumption that the conditioning variables are (approximately) constant during the time frame considered, allowing them to be differenced out. We are indebted to Nazrul Islam for pointing out that, while this is a reasonable assumption for many conditioning variables in the literature (e.g., an index of democracy for an international sample over 15 years), many of our county-level conditioning variables potentially vary significantly (e.g., the percent of the population employed in the communications industry over 28 years). To make sure that this did not introduce significant omitted variable bias into our estimations we ran the three first stage regressions for
} 
$\beta$ to recreate the component of a standard growth regression that would be related to the set of conditioning variables. This component can then be regressed on a constant and the conditioning variables, in "un-differenced" form, to estimate the effects of conditioning variables on balanced growth paths. This procedure ensures that none of the information contained in the levels of the conditioning variables is lost. ${ }^{11}$

Besides reporting OLS results below, as well as 2SLS results, for comparison, we also use a Hausman test as an additional aid in the determination of the appropriateness of the instrumental variable approach for the full U.S. sample. Two separate tests were performed. The first test was run on the $\beta$ values and yielded an $m$ value of 134.6. The second test was run on the entire model and yielded an $m$ value of 1236.6. Indeed, both tests reject the null hypothesis at the $1 \%$ level, thereby suggesting that the OLS estimates are inconsistent.

\section{U.S. County-Level Data}

The data for this study were drawn from several different sources. The majority of the data, however, came from the Bureau of Economic Analysis Regional Economic Information System (BEA-REIS) and U.S. Census data sets. ${ }^{12}$ The BEA-REIS data are largely based on the 1970, 1980 and 1990 decennial Census summary tape files, the 1972, 1977, 1982 and 1987 Census of Governments, the Census Bureau's City and County Book from various years. All dollar variables are expressed in constant 1992 prices. Natural logs were used throughout the project. We exclude military personnel from the measurements of both personal income and population.

Our entire data set includes 3,058 county-level observations. ${ }^{13}$ We examine the full sample, as well as U.S. states as economic units in and of themselves. We report

the full U.S. sample with differenced values of all conditioning variables included as regressors. All point estimates of $\beta$ from the modified first stages fell within the 95 percent confidence intervals of the Evans method first stage estimates. As well, if the $\beta$ estimates are not significantly affected then neither are the second stage results (see below).

${ }^{11}$ This is a point on which Barro (1997, p.37) has criticized panel data methods. As they rely on time series information, the conditioning variables are differenced. However, the conditioning variables often vary slowly over time such that the most important information is in the levels.

${ }^{12}$ We thank Jordan Rappaport for kindly sharing with us some of the data used in this study.

${ }^{13}$ The original data set contained 3,066 observations. Eight counties, however, were excluded from the data set for various reasons. Primarily, counties were excluded for lack of data. Examples of counties that fell into this category include counties in northern Alaska and some counties in Hawaii. Some data for 
estimation results for 32 of the 50 states. The standard we used for inclusion was whether or not, in the first-stage regressions, the estimate for $\beta$ was statistically different from zero.

The measure we use for personal income is that of the U.S. Bureau of Economic Analysis (BEA). ${ }^{14}$ The definitions that are used for the components of personal income for the county estimates are essentially the same as those used for U.S. national estimates. For example, the BEA defines "personal income" as the sum of wage and salary disbursements, other labor income, proprietors' income (with inventory valuation and capital consumption adjustments), rental income (with capital consumption adjustment), personal dividend income and personal interest income. (BEA, 1994) "Wage and salary disbursements" are measurements of pre-tax income paid to employees. "Other labor income" consists of payments by employers to employee benefit plans. "Proprietors' income" is divided into two separate components-farm and non-farm. Per capita income for a county is defined as the ratio of this personal income measure for the county to the population of the county. We adjust the personal income measure to be net of government transfers and express the value in per capita 1992 dollars using the U.S. GDP deflator. Natural logs of the real per capita income measures are used in the analysis. ${ }^{15}$

In addition to the per capita income variable we also utilize 39 demographic conditioning variables. In Table 1 we provide the complete list of the variables we use in this study along with their definitions. In the table we also provide the source of each series as well as the period it covers. ${ }^{16}$ All 39 of these variables were used for estimation using the full sample. However, only 33 of these were used for the with-in state estimations to preserve degrees of freedom. Our standard for exclusion was that a conditioning variable, in the second-stage regression using the full sample, resulted in a coefficient estimate with zeros to at least the fourth decimal place $(0.0000)$. The

these counties were simply not recorded as far back as 1970. Furthermore, in Virginia, some cities are themselves independent counties. If the data for these independent cities were available we let them stand as their own county. However, if the data were not available, then we tried to incorporate the independent city into the surrounding county. If that was not feasible, it was then dropped from the data set.

${ }^{14}$ The data and their measurement methods are described in detail in "Local Area Personal Income, 19691992" published by the BEA under the Regional Accounts Data, February 2, 2001.

${ }^{15}$ See the Data Appendix at the end of this paper more detailed descriptions of the personal income measure.

${ }^{16}$ See the data appendix for the construction/definition of metro and non-metro counties and regions. 
variables excluded from the within-state regressions were "land area," "water area," "education: public elementary," "education: public nursery," "education: private elementary," and "education: private nursery."

\section{Analysis of Convergence Rate Estimates}

The OLS and 2SLS estimates of $\beta$, the coefficient on the log of 1970 per capita income, are presented in Table 2 for the full U.S. sample and for 32 U.S. states. The speed of conditional convergence can be inferred from $\beta$. Associated with these estimates of $\beta$, Table 3 reports the asymptotic (conditional) convergence rates and associated 95 percent confidence intervals. ${ }^{17}$

For the full sample of 3,058 counties the 2SLS point estimate of the conditional convergence rate is 6.82 percent and is significant at the 1 percent level. This is compared to 2.37 percent using the inconsistent OLS method (also significant at the 1 percent level). The OLS 2.37 percent is similar to results reported by Barro and Sala-iMartin (1992), Mankiw et al (1992), and Sala-i-Martin (1996). The difference between the OLS and 2SLS estimate is nearly 300 percent. This suggests that OLS introduces substantial bias. The difference is economically large. A 2.37 percent convergence rate implies the gap between a the present per capita income level and the balanced growth path halves in 31 to 32 years, while a 6.82 percent rate implies the same in 12 to 13 years.

The basic finding that conditional convergence rates are higher than the 2 percent "mnemonic rule" of Sala-i-Martin (1996) holds when examining 32 states as economies in and of themselves. (The remaining states did not include enough county observations to be identified.) Figure 1 presents confidence intervals as vertical bars (that include the point estimates). The 2 percent rule is represented by a horizontal line. Every point estimate is above 2 percent, and the average point estimate is 8.1 percent. For one fourth

${ }^{17}$ Following Evans (1997b, footnote 17, p.16), we use $c=1-(1+T \beta)^{\frac{1}{T}}$ to compute the asymptotic rate of convergence. The confidence intervals (in parentheses) are obtained in two steps. First, we obtain end points of the $\beta$ confidence intervals by computing $\beta \pm(1.96 \times$ s.e. $)$, where s.e. is the standard error associated with the $\beta$ estimate. Next, these endpoints are plugged into $c=1-(1+T \beta)^{\frac{1}{T}}$. If the low value of the confidence interval is less than $-T^{-1}$, the higher value is equated to unity. It is clear from the above that the confidence intervals computed this way may be asymmetric around the point estimates. As Figure 1 indicates, this is indeed the case in our data. 
(8) of the states the point estimate is above 10 percent. (A 10 percent convergence rate implies that the distance from the balanced growth path is halved within 10 years.) Considering the 95 percent confidence intervals, for only 3 states is the lower bound of the confidence interval not greater than 2 percent (California, Iowa, and South Dakota all bottom out at 1.8 percent). These results are encouraging for laggard economies in the limited sense that, given proper policies/conditions to induce and support balanced growth paths similar to industrial leaders, the laggard economies can approach those balanced growth paths quickly relative to what previous research has suggested.

There is considerable heterogeneity in the estimated convergence rates. The standard deviation of the point estimates is 3.0 percent. Furthermore, Figure 1 suggests that confidence intervals do not overlap enough to dismiss heterogeneity. The pair wise absences of overlap in confidence intervals can be interpreted as statistical rejection of convergence rate homogeneity at the 95 percent level for given pairs of states. We can consider a given state and ask for how many other states can its convergence rate be rejected as the identical. For 7 states there is at least one other state for which their two convergence rates can be rejected as identical.

The full picture that one gets from Table $\mathbf{3}$ and Figure $\mathbf{1}$ is a group of economies with high rates of convergence relative to the 2 percent suggested by previous OLS-based empirics, but significant heterogeneity above that mark. This heterogeneity should not be surprising. The convergence rate in the neoclassical growth model is a function of the technology growth, population growth, and depreciations rates, as well as the parameters of the aggregate technology and the representative preferences on time and consumption. ${ }^{18}$ So differences in what particular industries predominate in an economy, cultural characteristics, and institutions can all translate into different convergence rates. Diminishing returns is always the general driving force, but the particulars vary.

\section{Analysis of Balanced Growth Path Determinants}

Just as there may be heterogeneity in the rates of convergence towards balanced growth paths, there may also be heterogeneity in the balance growth paths themselves. In particular, there can be heterogeneity in the height of the balanced growth path and/or the

\footnotetext{
${ }^{18}$ See Barro and Sala-i-Martin (1992) for details.
} 
slope of the path (the balanced growth rate). In this section we consider a selection of conditioning variables and their estimated coefficients. In our regressions, these coefficients indicate the effect of these variables on the average growth rate of per capita income indirectly via the height of the balanced growth paths. Given the height of a balanced growth path, the average growth rate increases (if the balanced growth path is higher) or decreases (if the balanced growth path is lower) as a result of the distance of per capita income from the balanced growth path and the convergence effect towards that path. $^{19}$

The variables we focus on here are grouped into public sector size variables, educational attainment variables, and industry composition variables. (Again, table 1 gives descriptions and sources of these and all other conditioning variables.) In each case we focus on 2SLS estimates. ${ }^{20}$ We discuss the results for the entire sample and we examine the results for states as individual economic units to address potential heterogeneity.

\section{i. $\quad$ Size of the Public Sector}

Does "big government" foster or hinder economic growth? This query expresses a fundamental concern about the proper extent of the public sector in economic life. A large literature has explored this question. ${ }^{21}$ In a cross section of countries, Barro (1991) found that a large public sector is growth hindering. Easterly and Rebelo (1993), also in a cross section of countries, found that public investment in transportation and communication are associated positively with economic growth, but that any links between growth and other fiscal variables are fragile. Evans and Karras (1994) reported

\footnotetext{
${ }^{19}$ If conditional convergence were to be rejected, then these coefficients would be interpreted as influences on economies' balanced growth rates. However, since we report results only for states where 2SLS convergence rates were statistically different than zero, conditioning variable coefficient estimates can be interpreted as effects on the height of balanced growth paths throughout this paper.

${ }^{20}$ Full results for all conditioning variables using both OLS and 2SLS are included in the referees appendix.

${ }^{21}$ The empirical framework used in this paper relates variables to the economic growth rate of economies. Many studies have, instead, focused on the level of income rather than its growth rate. Slemrod (1995) provided a review of these studies and their relation to growth rate studies. He noted that, "level studies primarily try to explain G [the extent of government] and include $\mathrm{Y}$ [income] as one explanatory variable; that $\mathrm{G}$ might affect $\mathrm{Y}$ is ignored [while] the growth studies try to explain the growth rate of $\mathrm{Y} \ldots$ and often include $\mathrm{G}$ as one of the explanatory variables"(p.399). The simultaneity problem must be noted. However, to keep discussion in this paper focused we refer only to the growth rate studies and, in particular, those based on the neoclassical growth model. For other approaches see Gramlich (1994) and Slemrod (1995).
} 
that government activities, with the exception of expenditures on education services, are either unproductive or affect growth negatively. More recently, Folster and Henrekson (2001) studied a panel of wealthy nations and concluded that there is a strong negative relationship between public expenditures and economic growth. ${ }^{22}$

All of the above studies used various government expenditure variables to capture the size and scope of government activities. We, in contrast, use the percent of a county's population employed by the federal, state and local governments. These variables offer several advantages over expenditure variables. First, separate measures for federal, state and local government allow us to explore how the relationship between extent of the public sector and growth differs at three levels of decentralization. Second, the three separate measures can help to alleviate problems of interpreting coefficients when externalities exist across economies. At least the local government variable should be nearly immune to spill-over effects.

Our government employment variables are also complementary to the expenditure variables of previous studies. First, the employment variables can be interpreted as a stock of government activities/roles producing a flow of services, while government expenditures are the flow of services itself. Second, while previous studies directly account for government expenditure, our employment variables directly account for the extent to which government is involved, i.e. the percent of labor force activities directed by government. $^{23}$ Third, while expenditure measures can often provide useful differentiation of roles of government (e.g. education versus other roles (Evans and Karras, 1994)), our employment variables provide another differentiation of roles (i.e. those associated with federal government versus those of state and local governments).

Table 4 summarizes the results for the full sample and for the same states reported for section 4 . In the full sample, we find a negative relationship between the

\footnotetext{
${ }^{22}$ An important paper by Levine and Renelt (1992) demonstrated that conclusions from cross-country regressions may not be robust to small changes in the set of conditioning variables. In particular, "a broad array of fiscal-expenditure variables [that have been] considered by the profession, are not robustly correlated with growth"(p.943). Of note, the 2SLS approach theoretically yields consistent estimators for conditioning variable coefficients regardless of the specific set included. As well, our set of conditioning variables is large (even in the individual state regressions (33)) and, therefore, minimizes omitted variable bias in practice.

${ }^{23}$ Of course, expenditure and involvement are not mutually exclusive. Government expends wages so that labor is involved in government activities.
} 
percent of the population employed by government and the rate of economic growth. The effect is negative and statistically significant regardless of whether one considers federal, state or local government. Furthermore, there is no clear pattern of the public sector having less of a negative effect at increasingly more decentralized levels. The coefficients for the federal, state and local variables are $-0.0222,-0.0163$, and -0.0204 respectively (all significant at the 1 percent level). ${ }^{24}$

Considering each state separately, there are numerous cases of significant coefficients on the government employment variables. In 9 out of 25 states examined, the federal government coefficient is significant at the 10 percent level or better; 8 out of 25 for the state government coefficients; 5 out of 25 for the local government coefficients. All but 2 of these 22 of these significant coefficient estimates are of negative sign. Interestingly, the only 2 positive coefficients are both for the state of North Dakota (the federal and local government employment variables) and are large (0.2289 and 0.2417 respectively). Aside from this outlier state, the results are qualitatively homogenous across states: government at all levels is negatively correlated with economic growth paths.

For individual state coefficients on the federal, state and local government variables there exists considerable overlap of the confidence intervals. In fact, using a 95 percent confidence standard, for the federal government coefficients no two can be rejected as identical. Similarly for the state variable coefficients. The only exception is the local government coefficient for North Dakota which is large, positive and significant at the 5 percent level. However, that North Dakota is an outlier in the analysis has already been noted. Setting that state aside, the overall picture that emerges is one where government at all levels hinders economic growth, and one where discernable differences between "good" versus "bad" government across states cannot be detected.

\footnotetext{
${ }^{24}$ While these findings suggest that an increased public sector hinders economic growth via distortion of incentives and diversion of resources, another possible interpretation is that non-government wage growth simply outpaces government wage growth. In Higgins et al (2003) we assembled government and nongovernment wage data for the 1970-1998 period. At the state and federal level, non-government wages outpaced government wages in only just above half of U.S. counties (55 percent), and at the local level, government wages grew faster in 70 percent of counties. So for federal and state levels, the story does not seem economically important enough to account for the estimated result, and at the local level it would work against a negative effect appearing.
} 


\section{ii. Educational Attainment}

As Table 1 indicates, our data include eight different variables measuring educational attainment within U.S. counties. We focus on four of these variables: the percent of the population with (a) 9-11 years of education, (b) a high school diploma and no more, (c) some college education but less than a bachelor degree, and (d) a bachelor degree and/or higher degrees. ${ }^{25}$ Table 5 reports the 2SLS coefficient estimates for the select educational attainment variables for the full sample and within-state samples.

We first consider the percent of the population with at least 9 years of education, but less than a high school (or its equivalent) degree. For the full sample the coefficient is -0.0221 and is significant at the 1 percent level. This seems sensible. It implies that the greater percentage of an economy's population without the remedial mathematics, writing and communications skills - as well as the minimum personal discipline and social behavior - necessary to obtain a high school diploma, the lower the economy's balanced growth path. Passing that threshold, the coefficient for the population achieving, but not surpassing, a high school diploma has a point estimate of 0.0097 (significant at the 1 percent level).

More surprisingly, for the full sample the coefficient for the percent of the population with some college education but not enough for a bachelor degree is negative and insignificant. Compare this to the coefficient on the percent of the population with a bachelor degree or more: 0.0732 and significant at the 1 percent level. A possible interpretation of this result concerns the opportunity cost of education. College education ostensibly involves a benefit in the form of increased skills/productivity for the individual, but it also involves a cost in the form of foregone wages. The results may imply that college education of at least 4 years represents (on average) a positive net return to individuals, while the net return on a 2-year degree is questionable. ${ }^{26}$

\footnotetext{
${ }^{25}$ The remaining four variables (for public and private elementary schools and nurseries) we get mixed results in the full sample in terms of statistical significance. Although two of them have statistically significant estimated coefficient values, none of the coefficients represent economically significant effects. The point estimates of all coefficients for the full sample are zero up to four decimals.

${ }^{26}$ Kane and Rouse (1995) and Surette (1997) reported that the estimated return to 2-year degrees is positive and equals about 4-6 percent and 7-10 percent, respectively. Neither of these studies uses county-level data. In addition, these studies do not take into account the social return, rather than the private return to individuals, as our results presumably do. Both Kane and Rouse and Surette's studies looked at individuals' costs (tuition, wages forgone, experience forgone, etc.) and benefits (wage premiums) while we consider the effect of educational attainment on the average growth of an economy over a 30-year
} 
In all four of these categories we can detect some heterogeneity across states. In the case of the less than high school degree attainment variable, there are 6 statistically significant (10 percent level or better) within-state coefficient estimates. They range from -0.0904 (South Dakota; 1 percent level) to 0.1171 (Colorado; 5 percent level). This result is puzzling. Why would there be some individual states where having a larger percent of the population without a high school diploma be conducive to economic growth? One potential explanation concerns compulsory education laws. The variable may include many people who would have had a high school education given their druthers, and benefited their economy by being forced to. On the other hand, there is an opportunity cost forced on rather-be-truant individuals and a direct cost on school system to deal with them as well. If individuals pushed through the school system while not receiving/accepting the benefits of education, they also forego the productive opportunities available meanwhile. However, the data is silent. Each of the 6 states has roughly similar age spans of compulsion - 7 to 16 (Alabama, Colorado, Illinois and North Carolina), 6 to 16 (South Dakota), or 6 to 18 (Texas) years old ${ }^{27}$ - and there is no apparent correlation between these small differences and the coefficient estimates.

Some heterogeneity also is detected across the significant high school diploma variable coefficients. Of the 8 coefficient estimates significant at the 10 percent level or better, 2 of them are negative (Mississippi and Ohio) and 1 has a 95 percent confidence interval entirely in the negative range (Mississippi). However, among the 6 coefficients with positive point estimates there is no statistically significant difference between them. One straightforward explanation for the detected heterogeneity is simply that schools are better in some states than others. This hypothesis can be informally tested by comparing average scholastic aptitude test (SAT) scores from the states with negative coefficient estimates to those with positive coefficient estimates. Indeed, Ohio has both the lowest

period. What we might be detecting in our results, therefore, is a questionable social return to associate degrees. This is a potentially important finding for policy-makers. As Kane and Rouse (1995, p.600n) noted, "Twenty percent of Federal Pell Grants, 10 percent of Guaranteed Student Loans, and over 20 percent of state expenditures for postsecondary education, go to community colleges."

${ }^{27}$ These laws are from a report by the U.S. Department of Education (2001a), except for the Colorado law, which comes from the Colorado Department of Education. 
math and verbal average scores. However, Mississippi has SAT average scores neither exceptionally high nor low relative to the other seven states. ${ }^{28}$

No statistically significant heterogeneity can be detected among coefficients for the some college variable. Still, it should be noted that every statistically significant coefficient is positive. We cannot detect heterogeneity for the bachelor degree or more variable either.

\section{iii. Industry Composition Effects}

Our data include 16 industry-level variables, each measuring the percent of the population employed in the given industry. Table 1 includes the full list. Here we focus on three industry categories that are of a priori interest and had significant estimated effects for the full sample: (a) finance, insurance and real estate, (b) educational services, and (c) entertainment and recreational services. The coefficients estimates for these variables for the full sample and individual state samples are summarized in Table 6.

\section{a. $\quad$ Finance, Insurance and Real Estate Services}

We find a significant, positive correlation between the percent of the population employed in finance, insurance and real estate services and economic growth in the full sample. The point coefficient estimate is 0.0777 and is significant at the 1 percent level. A possible reason for the correlation is a link between financial intermediation and economic growth. Rousseau and Wachtel (1998) use data from 1870 to 1920 to document quantitatively important links between financial intensity and per capita output levels in five OECD countries. Furthermore, Greenwood and Jovanovic (1990) and King and Levine (1993) provided theoretical models rationalizing this link. In the Greenwood and Jovanovic model, as financial intermediation becomes more prevalent, agents gain confidence in intermediaries' ability to allocate funds profitably. This leads to better matching of funds to productive investments and, consequently, to greater growth. In King and Levine's model, greater intermediation enhances information gathering potential and allows for funding of productive investment by less-well-established firms that otherwise would remain un-funded.

\footnotetext{
${ }^{28}$ The SAT score test of the hypothesis, however, relies on an assumption that the predominant portion of the population with high school degrees obtained their high school degrees in the considered state. For entire states, this seems a priori plausible but not certain.
} 
We find qualitative, as well as quantitative, heterogeneity across within state coefficients. For 7 states coefficient estimates are significant at the 10 percent level or better. For 2 states (Idaho and Louisiana) the estimates are negative. For each of the 7 states, the coefficient is statistically different (at the 95 percent level) from the coefficient of at least one other state. We find this interesting because, as Wachtel (2003, p.34) states, "Economists now take it for granted that a well-developed, market oriented financial sector contributes to economic growth." The significant negative correlations in 2 states begs the question of what forces are there thwarting the conventional wisdom. Unfortunately, an answer is beyond the scope of the present work.

\section{b. Educational Services}

Unlike educational attainment levels, the percent of the population providing education services is negatively correlated with economic growth in the full sample (point estimate -0.0334 and significant at the 1 percent level). Furthermore, no significant heterogeneity is detected across states. For the 6 states with coefficient estimates significant at the 10 percent level or better, each and every point estimate is negative. As well, only 1 state's coefficient estimate is significant at better than the 10 percent level (Indiana; 1 percent level). Therefore none of the coefficients are statistically different from another at the 5 percent level.

Why a negative correlation between the percent of the population providing educational services and economic growth? Perhaps the benefits of education provided in a county are not entirely internalized by the county itself. We report a positive correlation between human capital and economic growth (section 5.ii.), but the correlation is silent as to where the stock is accumulated. For example, individuals may attend college or university where human capital is relatively easy to accumulate, and then move to other counties as they join the workforce. ${ }^{29} 30$

\footnotetext{
${ }^{29}$ In Higgins et al (2003) we found that the negative association is particularly strong in metro counties. This is consistent with an externality argument in that a large proportion of colleges and universities are in metro areas, but many students leave the metro areas upon graduation. The effect in a sample of only nonmetro counties, as a matter of fact, was not statistically significant.

${ }^{30}$ Another explanation for the negative relationship is bureaucratic over-expansion of the public school systems. This hypothesis is frequently entertained in the popular media and was explored by Marlow (2001) in the California primary and secondary school districts. However, Marlow found that an increase in the number of teachers has no statistically significant effect on SAT scores or dropout rates, and an increase in the size of administrative staff increases the SAT scores and decreases dropout rates.
} 


\section{c. Entertainment and Recreational Services}

The estimated effect of the percent of the population employed in entertainment and recreation industries is positive and significant (1 percent level) in the full sample (point estimate 0.0477). This effect may be an important one. First, to put it in perspective, the estimated partial correlation is larger (in absolute value) than that for any of the public sector extent variables. Second, Costa (1997, Table 1) has reported that, as a percent of U.S. households' budgets, recreation expenditures rose from 1.9 percent around 1890, to 4.5 percent in 1950, and then 5.6 percent in 1991. Thus entertainment and recreation services comprise an increasingly large segment of the U.S. economy.

Within states, 6 had estimated coefficients significant at the 10 percent level or better. All of them are positive. There are only two coefficients estimates (California and Mississippi) that are statistically different from one another at the 5 percent level. ${ }^{31}$

The positive correlation between recreation and entertainment industry with economic growth might be capturing the attraction of economic activity to counties where gambling casinos and professional sports teams are located. Siegfried and Zimbalist (2000, p.114) reported that by 2005 there will be 95 professional sports stadiums having been constructed since 1990, and more than $\$ 27.1$ billion will be spent on these stadiums. ${ }^{32}$ Eadington (1999, p.173) reported that gross gaming revenues reached $\$ 540$ billion in 1997. In addition, Walker and Jackson (1998) documented economic growth being stimulated by the introduction of casino industries. The withinstate results can offer little insight into the above hypothesis. California, Georgia and New York all have at least one professional team in the NHL, NBA, MLB and NFL. However, Indiana has only an NBA team, and Louisiana and Mississippi have no teams in any of these major professional sports leagues. Likewise, Indiana, Louisiana and Mississippi allow for casinos, while California, Georgia and New York do not.

\section{Conclusions}

\footnotetext{
${ }^{31}$ Interestingly, of the 7 coefficient estimates, California has the lowest point estimate. It is still positive and significant but "common knowledge" might suggest that the home of Hollywood would be one where entertainment industry fostered economic growth.

32 "Professional sport" refers to the NHL, the MLB, the NFL and the NBA.
} 
We utilize a county-level data set to explore growth determination in the U.S. and possible heterogeneity in the determination process across individual states. The data set includes over 3,000 cross-sectional observations and 39 demographic conditioning variables to control for variation in the balanced growth paths. Combined with this data we exploit a consistent two stage least squares estimation procedure that does not bias convergence rate estimates downward (as does conventional OLS). However, we report OLS estimates as well.

Convergence across the U.S. averages nearly 7 percent per year - higher than the 2 percent normally found with OLS in cross-country and U.S. state samples. Across individual states, estimated convergence rates for 32 states are above 2 percent with an average of 8.1 percent. For 29 states the convergence rate is above 2 percent with 95 percent confidence. We find substantial heterogeneity in individual state convergence rates. For 7 states the convergence rate can be rejected as identical to at least one other state's convergence rate with 95 percent confidence. The high convergence rates are encouraging in the sense that, given proper policies to induce and support balanced growth paths similar to leader economies, laggard economies can close the gap relatively quickly to what previous research has suggested. However, there is a grain of salt. If significant heterogeneity exists in convergence rates across U.S. states, as the countylevel data indicates, the heterogeneity across different nations could be greater, and convergence rates could well be lower for certain economies.

In examining the determinants of balanced growth path heights, we find that government at all levels of decentralization is negatively correlated with economic growth. Educational attainment of a population has a non-linear relationship with economic growth according to our estimates: growth is positively related to high-school degree attainment, seemingly unrelated to obtaining some college education, and then positively related to four-year or more degree attainment. Also, finance, insurance and real estate industry and entertainment industry are positively correlated with growth, while education industry is negatively correlated with growth. Heterogeneity in the effects of balanced growth path determinants across individual states is much harder to detect or dismiss than heterogeneity of convergence rates. 


\section{Data Appendix: Measurement of Per Capita Income}

Because of the critical importance of the income variable for the study of growth and convergence, we want to address its measurement in some detail. Two options were available to us for the construction of the county-level per capita income variable: (1) Census Bureau database, and (2) BEA-REIS database.

Income information collected by the Census Bureau for states and counties is prepared decennially from the "long-form" sample conducted as part of the overall population census (BEA, 1994). This money income information is based on the selfreported values by Census Survey respondents. An advantage of the Census Bureau's data is that they are reported and recorded by place of residence. These data, however, are available only for the "benchmark" years, i.e., the years in which the decennial Census survey is conducted.

The second source for this data, and the one chosen for this project, is personal income as measured by the Bureau of Economic Analysis (BEA). ${ }^{33}$ The definitions that are used for the components of personal income for the county estimates are essentially the same as those used for the national estimates. For example, the BEA defines "personal income" as the sum of wage and salary disbursements, other labor income, proprietors' income (with inventory valuation and capital consumption adjustments), rental income (with capital consumption adjustment), personal dividend income and personal interest income. (BEA, 1994) "Wage and salary disbursements' are measurements of pre-tax income paid to employees. "Other labor income" consists of payments by employers to employee benefit plans. "Proprietors' income" is divided into two separate components-farm and non-farm. Per capita income is defined as the ratio of this personal income measure to the population of an area.

The BEA's estimates of personal income reflect the revised national estimates of personal income that resulted from the 1991 comprehensive revision and the 1992 and 1993 annual revisions of the national income and product accounts. The revised national estimates were incorporated into the local area estimates of personal income as part of a

\footnotetext{
${ }^{33}$ The data and their measurement methods are described in detail in "Local Area Personal Income, 19691992” published by the BEA under the Regional Accounts Data, February 2, 2001.
} 
comprehensive revision in May 1993. In addition, the estimates incorporate source data that were not available in time to be used in the comprehensive revisions. ${ }^{34}$

The BEA compiles data from several different sources in order to derive this personal income measure. Some of the data used to prepare the components of personal income are reported and recorded by place of work rather than place of residence. Therefore, the initial estimates of these components are on a place-of-work basis. Consequently, these initial place-of-work estimates are adjusted so that they will be on a place-of-residence basis and so that the income of the recipients whose place of residence differs from their place of work will be correctly assigned to their county of residence.

As a result, a place of residence adjustment is made to the data. This adjustment is made for inter-county commuters and border workers utilizing journey-to-work (JTW) data collected by Census. For the county estimates, the income of individuals who commute between counties is important in every multi-county metropolitan area and in many non-metropolitan areas. The residence adjustment estimate for a county is calculated as the total inflows of the income subject to adjustment to county $i$ from county $j$ minus the total outflows of the income subject to adjustment from county $i$ to county $j$. The estimates of the inflow and outflow data are prepared at the Standard Industrial Classification (SIC) level and are calculated from the JTW data on the number of wage and salary workers and on their average wages by county of work for each county of residence from the Population Census.

\footnotetext{
${ }^{34}$ For details of these revisions, see "Local Area Personal Income: Estimates for 1990-92 and Revisions to the Estimates for 1981-91," Survey of Current Business 74 (April 1994), 127-129.
} 


\section{References}

Anderson, Arthur \& Co. (1997), Economic Impacts of Casino Gambling in the United States, Volume 2: Micro Study (Washington, D.C.: American Gaming Assoc.)

Barro, Robert J. (1991), "Economic Growth in a Cross Section of Countries," Quarterly Journal of Economics 106, 407-443.

Barro, Robert J. and Xavier Sala-I-Martin (1991), "Convergence Across States and Regions," Brookings Papers on Economic Activity. 1, 107-158.

Barro, Robert J. and Sala-i-Martin, Xavier (1992), “Convergence,” Journal of Political Economy. 100, 223-251.

Brock, William A. and Steven N. Durlauf (2001), "Growth Empirics and Reality," Word Bank Economic Review. 15, 229-272.

Canova, Fabio (1999), "Testing for Convergence Clubs in Income Per Capita: A Predictive Density Approach," CEPR Working Paper 2201.

Cass, David (1965), "Optimum Growth in an Aggregative Model of Capital Accumulation," Review of Economic Studies. 32, 233-240.

Colorado Department of Education, "Title 22, Colorado Revised Statutes: Education Article 33: School Attendence Law of 1963 Section 104."

Costa, Dora L. (1997), “Less of a Luxury: The Rise of Recreation Since 1888," NBER Working Paper 6054, June.

Desdoigts, Alan (1999), "Patterns of Economic Development and the Formation of Clubs," Journal of Economic Growth. 4, 305-330.

Durlauf, Steven N. and Paul A. Johnson (1995), "Multiple Regimes and Cross-Country Growth Behaviour," Journal of Applied Econometrics. 10, 365-384.

Eadington, William R. (1999). "The Economics of Casino Gambling," Journal of Economic Perspectives. 13, 173-192.

Easterly, William and Sergio Rebelo (1993), "Fiscal Policy and Economic Growth," Journal of Monetary Economics 32, 417-458.

Evans, Paul (1997a), "How Fast Do Economies Converge?" Review of Economics and Statistics. 36, 219-225.

Evans, Paul (1997b), "Consistent Estimation of Growth Regressions," unpublished manuscript, available at http://economics.sbs.ohiostate.edu/pevans/pevans.html.

Evans, Paul (1998), “Using Panel Data to Evaluate Growth Theories," International Economics Review. 39, 295-306.

Evans, Paul and Georgios Karras (1994), “Are Government Activities Productive? Evidence from a Panel of U.S. States," Review of Economics and Statistics, Volume LXXVI, No. 1, 1-11.

Evans, Paul and Georgios Karras (1996), “Convergence Revisited," Journal of Monetary Economics. 37, 249-265.

Folster, Stefan and M. Henrekson (2001), "Growth Effects of Government Expenditure and Taxation in Rich Countries," European Economic Review. 45, 1501-1520.

Gramlich, Edward M. (1994), "Infrastructure Investment: A Review Essay," Journal of Economic Literature. 32, 1176-1196.

Greenwood, Jeremy and Boyan Jovanovic. (1990), "Financial Development, Growth, and the Distribution of Income," Journal of Political Economy. 98, 1076-1107.

Higgins, Matthew \& Daniel Levy and Andrew T. Young (2003), "Growth and Convergence Across the U.S.: Evidence from County-Level Data," 
Unpublished Working Paper.

Kane, Thomas J. and Cecilia E. Rouse. (1995), "Labor-Market Returns to Two- and Four-Year College," American Economic Review. 85, 600-614.

King, Robert G. and Ross Levine. (1993), "Finance and Growth: Schumpeter May be Right," Quarterly Journal of Economics. 108, 717-737.

Koopmans, Tjalling C. (1965), "On the Concept of Optimal Economic Growth," in The Econometric Approach to Development Planning (Amsterdam, N. Holland).

Lee, Kevin \& M. Hashem Pesaran and Ron Smith (1997), "Growth and Convergence in a Multi-Country Empirical Stochastic Growth Model," Journal of Applied Econometrics. 12, 357-384.

Mankiw, N. Gregory \& David Romer, and David N. Weil (1992), "A Contribution to the Empirics of Economic Growth, "Quarterly Journal of Economics. 107, 407-437.

Marlow, Michael L. (2001), "Bureaucracy and Student Performance in U.S. Public Schools," Applied Econometrics. 33, 1314-1350.

Quah, Danny T. (1996), "Twin Peaks: Growth and Convergence in Models of Distributional Dynamics," Economic Journal. 106, 1045-1055.

Quah, Danny T. (1997), "Empirics for Growth and Distribution: Stratification, Polarization, and Convergence Clubs," Journal of Economic Growth. 2, 27-59.

Ramsey, F. (1928), “A Mathematical Theory of Saving,” Economic Journal. 38, 543559.

Rousseau, Peter L. and Paul Wachtel. (1998), "Financial Intermediation and Economic Performance: Historical Evidence from Five Industrialized Countries," Journal of Money, Credit and Banking. 30, 657-678.

Sala-i-Martin, Xavier X. (1996), "Regional Cohesion: Evidence and Theories of Regional Growth and Convergence," European Economic Review. 40, 1325-1352.

Siegfried, John and Andrew Zimbalist. (2000), "The Economics of Sports Facilities and Their Communities," Journal of Economic Perspectives. 14, 95-114.

Slemrod, Joel (1995), "What Do Cross-Country Studies Teach Us about Government Involvement, Prosperity, and Economic Growth," BPEA 2, 373-431.

Solow, Robert M. (1956), "A Contribution to the Theory of Economic Growth," Quarterly Journal of Economics. 70, 65-94.

Summers, Robert and Alan Heston (1988), "A New Set of International Comparisons of Real Product and Prices: Estimates for 130 Countries," Review of Income and Welath. 34, 1-26.

Summer, Robert and Alan Heston (1991), "The Penn World Tables (Mark 5): An Expanded Set of International Comparisons 1950-1988," Quarterly Journal of Economics. 106, 327-368.

Surette, Brian J. (1997), "The Effects of Two-Year College on the Labor Market and Schooling Experiences of Young Men," Board of the Governors of the Federal Reserve System, Finance and Economic Discussion Series, No. 1997/44, September.

Swan, Trevor W. (1956), "Economic Growth and Capital Accumulation," Economic Record. 32, 334-361.

U.S. Department of Education (1999-2000). National Center for Education Statistics, Schools and Staffing Survey, 1999-2000. Tables 1.01 and 2.01.

U.S. Department of Education (2001). Digest of Education Statistics. Table 151. 
U.S. Department of Education (2001). Digest of Education Statistics. Table 137. Wachtel, Paul. (2003), "How Much do We Really Know about Growth and Finance?" Federal Reserve Bank of Atlanta Economic Review. 88, 33-48.

Walker, Douglas M. and John D. Jackson. (1998), "New Goods and Economic Growth," Review of Regional Studies. 28, 47-69. 
Table 1: Variable Definitions and their Source

\begin{tabular}{|c|c|c|c|}
\hline Variable & Definition & Period & Source \\
\hline Income & $\begin{array}{l}\text { Per Capita Personal Income (excluding } \\
\text { transfer payments) }\end{array}$ & 1969-1998 & $\mathrm{BEA}^{35}$ \\
\hline Land Area & Land Area in $\mathrm{km}^{2}$ & $1970-1990$ & Census $^{36}$ \\
\hline Water Area & Water Area in $\mathrm{km}^{2}$ & $1970-1990$ & Census \\
\hline Age: $5-13$ years & Percent of $5-13$ year olds in the population & $1970-1990$ & Census \\
\hline Age: $14-17$ years & $\begin{array}{l}\text { Percent of } 14-17 \text { year olds in the } \\
\text { population }\end{array}$ & $1970-1990$ & Census \\
\hline Age: $18-64$ years & $\begin{array}{l}\text { Percent of } 18-64 \text { year olds in the } \\
\text { population }\end{array}$ & $1970-1990$ & Census \\
\hline Age: $65+$ & Percent of $65+$ olds & $1970-1990$ & Census \\
\hline Blacks & Percent of Blacks & $1970-1990$ & Census \\
\hline Hispanic & Percent of Hispanics & $1970-1990$ & Census \\
\hline Education: 9-11 years & $\begin{array}{l}\text { Percent of population with } 11 \text { years } \\
\text { education or less }\end{array}$ & $1970-1990$ & Census \\
\hline Education: H.S. diploma & $\begin{array}{l}\text { Percent of population with high school } \\
\text { diploma }\end{array}$ & $1970-1990$ & Census \\
\hline Education: Some college & $\begin{array}{l}\text { Percent of population with some college } \\
\text { education }\end{array}$ & $1970-1990$ & Census \\
\hline Education: Bachelor + & $\begin{array}{l}\text { Percent of population with bachelor degree } \\
\text { or above }\end{array}$ & $1970-1990$ & Census \\
\hline Education: Public elementary & $\begin{array}{l}\text { Number of students enrolled in public } \\
\text { elementary schools }\end{array}$ & $1970-1990$ & Census \\
\hline Education: Public nursery & $\begin{array}{l}\text { Number of students enrolled in public } \\
\text { nurseries }\end{array}$ & $1970-1990$ & Census \\
\hline Education: Private elementary & $\begin{array}{l}\text { Number of students enrolled in private } \\
\text { elementary schools }\end{array}$ & $1970-1990$ & Census \\
\hline Education: Private nursery & $\begin{array}{l}\text { Number of students enrolled in private } \\
\text { nurseries }\end{array}$ & $1970-1990$ & Census \\
\hline Housing & Median house value & $1970-1990$ & Census \\
\hline Federal government employment & $\begin{array}{l}\text { Percent of population employed by the } \\
\text { federal government in the county }\end{array}$ & 1969-1998 & BEA \\
\hline State government employment & $\begin{array}{l}\text { Percent of population employed by the } \\
\text { state government in the county }\end{array}$ & 1969-1998 & BEA \\
\hline Local government employment & $\begin{array}{l}\text { Percent of population employed by the } \\
\text { local government in the county }\end{array}$ & $1969-1998$ & BEA \\
\hline Self-employment & Percent of population self-employed & $1970-1990$ & Census \\
\hline Agriculture & $\begin{array}{l}\text { Percent of population employed in } \\
\text { agriculture }\end{array}$ & $1970-1990$ & Census \\
\hline Communications & $\begin{array}{l}\text { Percent of population employed in } \\
\text { communications }\end{array}$ & $1970-1990$ & Census \\
\hline Construction & $\begin{array}{l}\text { Percent of population employed in } \\
\text { construction }\end{array}$ & $1970-1990$ & Census \\
\hline Finance, insurance $\&$ real estate & $\begin{array}{l}\text { Percent of population employed in finance, } \\
\text { insurance, and real estate }\end{array}$ & $1970-1990$ & Census \\
\hline Manufacturing: durables & $\begin{array}{l}\text { Percent of population employed in } \\
\text { Manufacturing of durables }\end{array}$ & $1970-1990$ & Census \\
\hline Manufacturing: non-durables & $\begin{array}{l}\text { Percent of population employed in } \\
\text { manufacturing of non-durables }\end{array}$ & 1970-1990 & Census \\
\hline Mining & Percent of population employed in mining & $1970-1990$ & Census \\
\hline Retail & $\begin{array}{l}\text { Percent of population employed in retail } \\
\text { trade }\end{array}$ & $1970-1990$ & Census \\
\hline Business \& repair services & $\begin{array}{l}\text { Percent of population employed in } \\
\text { business and repair services }\end{array}$ & $1970-1990$ & Census \\
\hline Educational services & $\begin{array}{l}\text { Percent of population employed in } \\
\text { education services }\end{array}$ & $1970-1990$ & Census \\
\hline Professional related services & $\begin{array}{l}\text { Percent of population employed in } \\
\text { professional services }\end{array}$ & $1970-1990$ & Census \\
\hline Health services & $\begin{array}{l}\text { Percent of population employed in health } \\
\text { services }\end{array}$ & $1970-1990$ & Census \\
\hline
\end{tabular}

35 All BEA variables are available for each year from 1969-1998.

${ }^{36}$ Note, all Census variables are gathered from the 1970, 1980 \& 1990 Census tapes. Values for 1969 were obtained via the interpolation method as discussed in the data section. 
Table 1: Variable Definitions and their Sources (Cont.)

\begin{tabular}{|l|l|l|l|}
\hline Personal services & $\begin{array}{l}\text { Percent of population employed in } \\
\text { personal services }\end{array}$ & $1970-1990$ & Census \\
\hline $\begin{array}{l}\text { Entertainment \& recreational } \\
\text { services }\end{array}$ & $\begin{array}{l}\text { Percent of population employed in } \\
\text { entertainment and recreational services }\end{array}$ & $1970-1990$ & Census \\
\hline Transportation & $\begin{array}{l}\text { Percent of population employed in } \\
\text { transportation }\end{array}$ & $1970-1990$ & Census \\
\hline Wholesale trade & $\begin{array}{l}\text { Percent of population employed in } \\
\text { wholesale trade }\end{array}$ & $1970-1990$ & Census \\
\hline Poverty & $\begin{array}{l}\text { Percent of the population living at or } \\
\text { below the poverty level }\end{array}$ & $1970-1990$ & Census \\
\hline Metro area, 1970 & $\begin{array}{l}\text { Dummy Variable: 1 if the county was in a } \\
\text { metro area in 1970, and 0 otherwise }\end{array}$ & 1970 & Census \\
\hline
\end{tabular}


Table 2: Analysis of Beta Values

\begin{tabular}{|c|c|c|c|c|}
\hline State & $\underline{\text { Number of Counties }}$ & Unconditional & OLS & 2SLS \\
\hline United States ${ }^{37}$ & 3,058 & $-0.0068(15.88)^{*}$ & $-0.0174(22.15)^{*}$ & $-0.0345(24.19)^{*}$ \\
\hline Alabama & 67 & $-0.0039(1.56)$ & $-0.0251(2.38)^{* *}$ & $-0.0334(20.49)^{*}$ \\
\hline Arkansas & 74 & $-0.0086(3.20)^{*}$ & $-0.0267(4.48)^{*}$ & $-0.0384(22.08)^{*}$ \\
\hline California & 58 & $0.0218(3.99)^{*}$ & $-0.0261(2.50)^{* * *}$ & $-0.0235(4.87)^{*}$ \\
\hline Colorado & 63 & $-0.0041(1.26)$ & $-0.0134(2.53)^{* *}$ & $-0.0318(13.41)^{*}$ \\
\hline Florida & 67 & $0.0026(0.81)$ & $-0.0190(2.06)^{* *}$ & $-0.0319(14.98)^{*}$ \\
\hline Georgia & 159 & $-0.0065(3.09)^{*}$ & $-0.0171(4.33)^{*}$ & $-0.0367(36.46) *$ \\
\hline Idaho & 44 & $-0.0182(3.66)^{*}$ & $-0.0403(2.23)^{* *}$ & $-0.0406(10.03)^{*}$ \\
\hline Illinois & 102 & $-0.0030(1.41)$ & $-0.0255(5.46)^{*}$ & $-0.0281(9.07)^{*}$ \\
\hline Indiana & 92 & $0.0004(0.11)$ & $-0.0061(1.02)$ & $-0.0299(9.25)^{*}$ \\
\hline Iowa & 99 & $-0.0069(1.85)^{* * *}$ & $-0.0288(5.65)^{*}$ & $-0.0289(4.75)^{*}$ \\
\hline Kansas & 106 & $-0.0163(7.84)^{*}$ & $-0.0286(9.76)^{*}$ & $-0.0301(12.18)^{*}$ \\
\hline Kentucky & 120 & $-0.0043(2.85)^{*}$ & $-0.0253(6.11)^{*}$ & $-0.0354(19.74)^{*}$ \\
\hline Louisiana & 64 & $-0.0032(1.22)$ & $-0.0222(3.83)^{*}$ & $-0.0413(13.83)^{*}$ \\
\hline Michigan & 83 & $0.0056(2.14)^{* *}$ & $-0.0104(1.36)$ & $-0.0387(16.52)^{*}$ \\
\hline Minnesota & 87 & $-0.0056(2.44)^{* *}$ & $-0.0156(2.85)^{*}$ & $-0.0260(9.34)^{*}$ \\
\hline Mississippi & 82 & $0.0012(0.43)$ & $-0.0182(2.05)^{* * *}$ & $-0.0448(13.43)^{*}$ \\
\hline Missouri & 115 & $-0.0038(2.34)^{* *}$ & $-0.0171(3.78)^{*}$ & $-0.0455(10.74)^{*}$ \\
\hline Montana & 56 & $-0.0244(5.31)^{*}$ & $-0.0229(3.31)^{*}$ & $-0.0328(9.14)^{*}$ \\
\hline New York & 62 & $0.0120(4.45)^{*}$ & $0.0129(1.24)$ & $-0.0264(7.78)^{*}$ \\
\hline North Carolina & 100 & $-0.0033(1.47)$ & $-0.0171(3.32)^{*}$ & $-0.0467(7.11)^{*}$ \\
\hline North Dakota & 53 & $-0.0119(1.85)^{* * *}$ & $-0.0279(3.29)^{*}$ & $-0.0594(4.79)^{*}$ \\
\hline Ohio & 88 & $0.0047(1.83)^{* * *}$ & $-0.0136(1.87)^{* * * *}$ & $-0.0274(7.68)^{*}$ \\
\hline Oklahoma & 77 & $-0.0123(6.49)^{*}$ & $-0.0248(3.95)^{*}$ & $-0.0387(22.11)^{*}$ \\
\hline Pennsylvania & 67 & $0.0038(1.31)$ & $-0.0176(2.53)^{* *}$ & $-0.0312(9.01)^{*}$ \\
\hline South Carolina & 46 & $0.0014(0.53)$ & $-0.0118(0.62)$ & $-0.0336(5.97)^{*}$ \\
\hline South Dakota & 66 & $0.0003(0.06)$ & $-0.0193(2.39)^{* *}$ & $-0.0265(4.77)^{*}$ \\
\hline Tennessee & 97 & $-0.0002(0.07)$ & $-0.0199(3.55)^{*}$ & $-0.0392(15.21)^{*}$ \\
\hline Texas & 254 & $-0.0086(5.09)^{*}$ & $-0.0211(8.10)^{*}$ & $-0.0356(15.18)^{*}$ \\
\hline Virginia & 84 & $0.0016(0.62)$ & $-0.0045(0.69)$ & $-0.0348(15.81)^{*}$ \\
\hline Washington & 39 & $-0.0129(1.96)^{* *}$ & $-0.0349(1.09)$ & $-0.0327(9.29)^{*}$ \\
\hline West Virginia & 55 & $-0.0053(1.81)^{* * *}$ & $0.0043(0.43)$ & $-0.0336(15.49)^{*}$ \\
\hline Wisconsin & 70 & $-0.0009(0.37)$ & $-0.0191(3.08)^{*}$ & $-0.0240(6.83)^{*}$ \\
\hline
\end{tabular}

$t$-statistics are reported in parentheses

* $\quad$ significant at $1 \%$ level

** $\quad$ significant at $5 \%$ level

*** significant at $10 \%$ level

${ }^{37}$ See Higgins, Levy and Young (2002). 
Table 3 Asymptotic Convergence Rates - Point Estimates \& 95\% Confidence Intervals

\begin{tabular}{|c|c|c|c|}
\hline$\underline{\text { State }}$ & Number of Counties & OLS Estimates \& 95\% C.I. ${ }^{38}$ & _SLS Estimates \& C.I. __ \\
\hline United States ${ }^{39}$ & 3,058 & $0.0237(0.0208,0.0267)$ & $0.0682(0.0544,0.0911)$ \\
\hline Alabama & 67 & $0.0424(0.0036,0.1080)$ & $0.0931(0.0492,0.1466)$ \\
\hline Arkansas & 74 & $0.0479(0.0166,0.1098)$ & $0.0738(0.0570,0.1363)$ \\
\hline California & 58 & $0.0457(0.0046,0.1249)$ & $0.0375(0.0178,0.0868)$ \\
\hline Colorado & 63 & $0.0166(0.0031,0.0384)$ & $0.0759(0.0426,0.1009)$ \\
\hline Florida & 67 & $0.0268(0.0010,0.1109)$ & $0.0767(0.0480,0.1174)$ \\
\hline Georgia & 159 & $0.0230(0.0109,0.0413)$ & $0.1043(0.0699,0.1142)$ \\
\hline Idaho & 44 & $0.0892(0.0021,0.1566)$ & $0.0913(0.0471,0.1145)$ \\
\hline Illinois & 102 & $0.0434(0.0213,0.1168)$ & $0.0537(0.0337,0.1062)$ \\
\hline Indiana & 92 & $0.0067(-0.0054,0.0245)$ & $0.0622(0.0354,0.1221)$ \\
\hline Iowa & 99 & $0.0570(0.0224,0.1176)$ & $0.0574(0.0175,0.0954)$ \\
\hline Kansas & 106 & $0.0560(0.0360,0.1086)$ & $0.0639(0.0434,0.1228)$ \\
\hline Kentucky & 120 & $0.0431(0.0233,0.0922)$ & $0.1054(0.0561,0.1160)$ \\
\hline Louisiana & 64 & $0.0341(0.0128,0.0955)$ & $0.1555(0.0989,0.1940)$ \\
\hline Michigan & 83 & $0.0121(-0.0043,0.0427)$ & $0.1152(0.0536,0.1659)$ \\
\hline Minnesota & 87 & $0.0202(0.0053,0.0459)$ & $0.0454(0.0305,0.0719)$ \\
\hline Mississippi & 82 & $0.0249(0.0009,0.1509)$ & $0.1405(0.0455,0.1923)$ \\
\hline Missouri & 115 & $0.0230(0.0094,0.0452)$ & $0.0817(0.0387,0.1132)$ \\
\hline Montana & 56 & $0.0359(0.0099,0.0996)$ & $0.0865(0.0367,0.1566)$ \\
\hline New York & 62 & $0.0111(-0.0238,0.0284)$ & $0.0465(0.0285,0.0853)$ \\
\hline North Carolina & 100 & $0.0228(0.0078,0.0491)$ & $0.1302(0.0966,0.1574)$ \\
\hline North Dakota & 53 & $0.0528(0.0103,0.1247)$ & $0.0761(0.0353,0.1102)$ \\
\hline Ohio & 88 & $0.0170(-0.0005,0.0520)$ & $0.0503(0.0299,0.1059)$ \\
\hline Oklahoma & 77 & $0.0415(0.0139,0.1136)$ & $0.1152(0.0574,0.1437)$ \\
\hline Pennsylvania & 67 & $0.0240(0.0043,0.0707)$ & $0.0705(0.0291,0.1099)$ \\
\hline South Carolina & 46 & $0.0142(-0.0147,0.1259)$ & $0.0960(0.0243,0.1315)$ \\
\hline South Dakota & 66 & $0.0274(0.0036,0.1391)$ & $0.0406(0.0184,0.1144)$ \\
\hline Tennessee & 97 & $0.0287(0.0102,0.0689)$ & $0.0681(0.0488,0.1168)$ \\
\hline Texas & 254 & $0.0312(0.0208,0.0458)$ & $0.1170(0.0675,0.1564)$ \\
\hline Virginia & 84 & $0.0047(-0.0074,0.0227)$ & $0.0703(0.0500,0.1271)$ \\
\hline Washington & 39 & $0.0518(-.0119,0.0971)$ & $0.0845(0.0448,0.1449)$ \\
\hline West Virginia & 55 & $0.0040(-0.0184,0.0199)$ & $0.0634(0.0466,0.0972)$ \\
\hline Wisconsin & 70 & $0.0270(0.0077,0.0716)$ & $0.0390(0.0231,0.0688$ \\
\hline
\end{tabular}

\footnotetext{
${ }^{38}$ Asymptotic convergence rates and $95 \%$ confidence intervals in parentheses reflect observations whose beta values, in Table 1, are not significant.

${ }^{39}$ See Higgins, Levy and Young (2002) for full set of results for the United States.
} 
Table 4: Analysis of Select Government Variables

\section{Federal Government Employment}

2SLS

$-0.0222(4.26)^{*}$

$0.0391(0.72)$

$-0.0142(0.29)$

$0.0352(1.23)$

$-0.0609(1.69)^{* * * *}$

$0.0280(0.38)$

$-0.0100(0.28)$

$-0.1102(1.94)^{* * * *}$

$0.0405(1.24)$

$-0.0968(2.03)^{* * *}$

$0.0541(1.43)$

$0.0253(0.64)$

$-0.0192(1.85)^{* * *}$

$-0.0252(1.73)^{* * * *}$

$0.0716(1.45)$

$0.0371(0.61)$

$0.0127(0.21)$

$-0.0917(2.94)^{*}$

$-0.0854(1.37)$

$0.0966(0.80)$

$-0.1674(3.06)^{*}$

$0.2289(2.00)^{* * *}$

$-0.0232(0.41)$

$-0.1022(1.95)^{* * *}$

$0.0167(0.27)$

$-0.0164(0.20)$

$-0.0488(1.05)$

$-0.0032(0.10)$

$-0.0307(0.96)$

$-0.0166(0.42)$

$-0.0268(0.42)$

$0.0862(1.20)$

$0.0147(0.45)$
$(-0.0119,-0.0324)$ $(-0.0714,0.1497)$ $(-0.1138,0.0854)$ $(-0.0239,0.0944)$ $(-0.1384,0.0165)$ $(-0.1214,0.1775)$ $(-0.0802,0.0601)$ $(-0.2367,0.0162)$ $(-0.0247,0.1058)$ $(-0.1654,0.0438)$ $(-0.0212,0.1294)$ $(-0.0535,0.1042)$ $(-0.0644,0.0258)$ $(-0.0957,0.0451)$ $(-0.0273,0.1706)$ $(-0.1588,0.0845)$ $(-0.1092,0.1347)$ $(-0.1539,-0.0295)$ $(-0.2149,0.0441)$ $(-0.1519,0.3452)$ $(-0.2767,-0.0582)$ $(-0.0095,0.4274)$ $(-0.1375,0.0910)$ $(-0.2078,0.0034)$ $(-0.1101,0.1435)$ $(-0.1920,0.1591)$ $(-0.1433,0.0455)$ $(-0.0703,0.0638)$ $(-0.0938,0.0323)$ $(-0.0975,0.0642)$ $(-0.1930,0.1392)$ $(-0.0631,0.2356)$ $(-0.0522,0.0818)$
_State Government Employment

2SLS

$-0.0163(4.07)^{*}$

$-0.0131(0.27)$

$-0.0408(1.13)$

$0.0331(0.84)$

$-0.0605(1.66)^{* * *}$

$0.0049(0.09)$

$0.0035(0.15)$

0.0364 (1.10)

$-0.0095(0.51)$

$-0.0043(0.18)$

$-0.0457(2.32)^{* * *}$

$0.0108(0.67)$

$-0.0041(0.20)$

$-0.0160(0.49)$

$-0.0631(2.33)^{* *}$

$-0.0108(0.47)$

$-0.0396(0.84)$

$-0.0655(2.77)^{*}$

$-0.0057(0.14)$

0.0531 (1.19)

$-0.0432(1.78)^{* * *}$

0.1278 (1.55)

$-0.0318(1.35)$

$-0.0642(1.84)^{* * * *}$

$0.0252(0.96)$

$-0.0734(1.76)^{* * *}$

$-0.0014(0.04)$

$-0.0615(1.83)^{* * *}$

$-0.0021(0.11)$

$-0.0122(0.29)$

$-0.0691(0.57)$

$0.0147(0.41)$

$-0.0208(0.68)$

$$
\text { 95\% C.I. }
$$

$(-0.0085,-0.0242)$ $(-0.1112,0.0851)$ $(-0.1135,0.0319)$ $(-0.0477,0.1140)$

$(-0.1452,0.0240)$

$(-0.1082,0.1181)$

$(-0.0432,0.0503)$

$(-0.0371,0.1098)$

$(-0.0473,0.0281)$

(-0.0528,

$(-0.0528,0.0442)$

$(-0.0849,-0.0064)$

$(-0.0213,0.0431)$

$(-0.0440,0.0358)$

$(-0.0832,0.0511)$

$(-0.1174,-0.0087)$

$(-0.0577,0.0360)$

$(-0.1341,0.0548)$

$(-0.1125,-0.0184)$

$(-0.0911,0.0797)$

$(-0.0382,0.1446)$

$(-0.0919,0.0053)$

$(-0.0445,0.3001)$

$(-0.0792,0.0154)$

(-0.1346, 0

$(-0.2846,0.1376)$

$(-0.0719,0.0691)$

$(-0.1288,0.0057)$

$(-0.0385,0.0343)$

$(-0.0964,0.0718)$

$(-0.3816,0.2434)$

$(-0.0591,0.0885)$
_Local Government Employment

2SLS

$-0.0204(3.91)^{*}$

$0.0379(0.71)$

$-0.0392(0.90)$

$0.0462(0.72)$

$-0.0215(0.61)$

$-0.0244(0.28)$

$0.0144(0.48)$

$0.0280(0.41)$

$-0.0009(0.04)$

$-0.0319(0.87)$

$0.0135(0.51)$

$-0.0078(0.30)$

$-0.1652(2.85) *$

$-0.0332(0.97)$

$-0.0246(1.03)$

$-0.1485(2.51)^{*}$

$-0.0205(0.70)$

$-0.0132(0.32)$

$0.0072(0.11)$

$-0.0038(0.07)$

$0.2417(2.55)^{* *}$

$-0.0202(0.43)$

$-0.0902(2.46)^{* * *}$

$-0.1365(2.22)^{* *}$

$-0.0184(0.17)$

$-0.0544(1.23)$

$0.0067(0.19)$

$-0.0306(1.35)$

$0.0234(0.44)$

$-0.1572(0.69)$

$-0.0250(0.31)$

$0.0459(1.33)$
95\% C.I.

$(-0.0101,-0.0305)$ $(-0.0712,0.1472)$ $(-0.1277,0.0491)$

$(-0.0856,0.1782)$

$(-0.0941,0.0511)$

$(-0.1997,0.1508)$

$(-0.0455,0.0745)$

$(-0.1239,0.1801)$

$(-0.0485,0.0467)$

$(-0.1059,0.0419)$

$(-0.0400,0.0671)$

$(-0.0154,0.0513)$

$(-0.0599,0.0442)$

$(-0.2836,-0.0467)$

$(-0.1021,0.0355)$

$(-0.0725,0.0232)$

$(-0.2673,-0.0297)$

$(-0.0783,0.0373)$

$(-0.0995,0.0731)$

$(-0.1321,0.1466)$

$(-0.1112,0.1034)$

$(0.0439,0.4349)$

$(-0.1146,0.0741)$

$(-0.1641,-0.0163)$

$(-0.2616,-0.0113)$

$(-0.2544,0.2174)$

$(-0.1449,0.0359)$

$(-0.0658,0.0794)$

$(-0.0755,0.0141)$

$(-0.0826,0.1295)$

$(-0.7462,0.4316)$

$(-0.1939,0.1438)$

$(-0.0242,0.1162)$

\footnotetext{
-statistics are reported in parenthese

* significant at $1 \%$ leve

** significant at $5 \%$ level

*** significant at $10 \%$ level
} 
Table 5: Analysis of Select Education Variables

Some High School Education

$\underline{\text { Region }}$

United States

Alabama

Arkansas

California

Colorado

Florida

Georgia

Idaho

Illinois

Indiana

Iowa

Kansas

Kentucky

Louisiana

Michigan

Minnesota

Mississippi

Missouri

Montana

New York

North Carolina

North Dakota

Ohio

Oklahoma

Pennsylvania

South Carolina

South Dakota

Tennessee

Texas

Virginia

Washington

West Virginia

Wisconsin
High School Diploma

2SLS

\section{$(-0.0292,-0.0152)$}

$(0.0015,0.1649)$

$(-0.0844,0.0397)$

$(-0.2041,0.0694)$

$(0.0191,0.2151)$

$(-0.1282,0.1193)$

$(-0.0210,0.0384)$

$(-0.0859,0.2085)$

$(-0.0952,-0.0223)$

$(-0.0842,0.0175)$

$(-0.0803,0.0174)$

$(-0.0697,0.0135)$

$(-0.0410,0.0692)$

$(-0.0410,0.0692)$

$(-0.0340,0.0717)$

$(-0.1067,0.0211)$

$(-0.0803,0.0520)$

$(-0.0551,0.0743)$

$(-0.0773,0.0319)$

$(-0.2529,0.0368)$

$(-0.0616,0.1229)$

$(-0.0031,0.0821)$

$(-0.0031,0.0821)$

$(-0.0735,0.1354)$

$(-0.0400,0.0742)$

$(-0.0769,0.0732)$

$(-0.0626,0.0584)$

$(-0.1160,0.0962)$

$(-0.1621,-0.0186)$

$(-0.0477,0.0665)$

$(-0.0477,0.0665)$

$(-0.0836,-0.0353)$

$(-0.0412,0.0668)$

$(-0.3521,0.4135)$

$(-0.0733,0.1674)$

$(-0.0855,0.0308)$
0.0097 (3.26)*

$0.0832(2.07)^{* *}$ $0.0153(0.49)$

$-0.0212(0.60)$

$0.0654(2.23) * *$

$0.0649(0.95)$

$0.0103(0.60)$

$0.0893(2.31)^{* * *}$

$-0.0149(1.38)$

$-0.0220(1.37)$

$-0.0003(0.03)$

$0.0556(4.49)^{*}$

$0.0562(3.07) *$

$-0.0178(0.86)$

$-0.0187(0.77)$

$0.0053(0.31)$

$-0.0950(2.24)^{* *}$

$0.0187(1.11)$

$-0.0028(0.07)$

$-0.0719(1.51)$

$0.0223(1.07)$

$-0.0729(1.82)^{* * * *}$

$-0.0317(1.87)^{* * * *}$

$0.0556(2.43)^{* * *}$

-0.0331 (1.59)

$-0.1084(1.48)$

$0.0181(0.80)$

$0.0077(0.26)$

$0.0061(0.45)$

$0.0157(0.54)$

$0.0146(0.12)$

$-0.0223(0.50)$

$-0.0268(1.62)$

$$
95 \% \text { C. }
$$ \\ 95\% C.I}

$(0.0038,0.0156)$

$(0.0014,0.1649)$

$(-0.0478,0.0786)$

$(-0.0941,0.0515)$

$(0.0053,0.1255)$

$(-0.0750,0.2048)$

$(-0.0240,0.0447)$

$(0.0031,0.1755)$

$(-0.0364,0.0066)$

$(-0.0542,0.0102)$

$(-0.0245,0.0238)$

$(0.0309,0.0804)$

$(0.0198,0.0925)$

$(-0.0600,0.0243)$

$(-0.0677,0.0302)$

$(-0.0290,0.0396)$

$(-0.1804,-0.0095)$

$(-0.0149,0.0523)$

$(-0.0856,0.0799)$

$(-0.1697,0.0258)$

$(-0.0193,0.0641)$

$(-0.1568,0.0108)$

$(-0.0656,0.0022)$

$(0.0095,0.1017)$

$(-0.0754,0.0091)$

$(-0.2676,0.0508)$

$(-0.0279,0.0642)$

$(-0.0511,0.0666)$

$(-0.0208,0.0330)$

$(-0.0429,0.0744)$

$(-0.2885,0.3178)$

$(-0.1146,0.0700)$

$(-0.0605,0.0067)$

\begin{tabular}{c}
\hline$\underline{2 S L S}$ \\
\hline$-0.0025(0.41)$ \\
$0.1229(1.41)$ \\
$0.0492(0.75)$ \\
$0.0513(0.77)$ \\
$0.0600(0.90)$ \\
$0.1813(1.69)^{* *}$ \\
$0.0715(1.77)^{* *}$ \\
$-0.0052(0.11)$ \\
$0.0280(0.89)$ \\
$0.1129(2.09)^{* *}$ \\
$0.0157(0.58)$ \\
$-0.0031(0.16)$ \\
$0.0769(1.77)^{* * *}$ \\
$0.0717(1.19)$ \\
$-0.0079(0.15)$ \\
$0.0441(1.23)$ \\
$-0.0352(0.57)$ \\
$-0.0271(0.71)$ \\
$0.0100(0.24)$ \\
$0.0193(0.26)$ \\
$-0.0162(0.34)$ \\
$0.1838(2.78)^{* *}$ \\
$0.1305(2.62)^{*}$ \\
$0.0728(1.54)$ \\
$0.0121(0.20)$ \\
$0.1236(0.66)$ \\
$0.0352(0.72)$ \\
$-0.0673(1.10)$ \\
$0.0282(1.28)$ \\
$-0.0211(0.28)$ \\
$0.0199(0.28)$ \\
$-0.0134(0.15)$ \\
$0.0229(0.71)$
\end{tabular}

Bachelor Degree or Higher

$\underline{2 \text { SLS }} \quad 95 \%$ C.I.

$0.0732(12.01)^{*} \quad(0.0613,0.0852)$

$0.0448(0.77) \quad(-0.0741,0.1639)$

$0.1188(1.56) \quad(-0.0346,0.2723)$

$0.1003(2.36)^{*} \quad(0.0126,0.1880)$

$0.1178(3.03) * \quad(0.0382,0.1974)$

$0.1094(1.28) \quad(-0.0647,0.2837)$

$0.0279(0.90) \quad(-0.0335,0.0894)$

$0.0656(0.65) \quad(-0.1579,0.2891)$

$0.0495(1.61) \quad(-0.0117,0.1108)$

$0.0406(0.82) \quad(-0.0584,0.1396)$

$-0.0369(1.20) \quad(-0.0983,0.0244)$

$0.0403(1.54) \quad(-0.0118,0.0925)$

$0.0711(1.55) \quad(-0.0202,0.1625)$

$0.0707(1.19) \quad(-0.0508,0.1922)$

$0.0873(2.44)^{* *} \quad(0.0154,0.1592)$

$0.0273(0.64) \quad(-0.0578,0.1126)$

$0.0182(0.25) \quad(-0.1294,0.1659)$

$0.1255(3.50) * \quad(0.0542,0.1969)$

$0.0085(0.17) \quad(-0.0983,0.1154)$

$0.1734(3.31)^{*} \quad(0.0661,0.2807)$

$0.1134(3.02) * \quad(0.0384,0.1883)$

$0.1245(1.35) \quad(-0.0677,0.3167)$

$0.0691(1.58) \quad(-0.0187,0.1571)$

$0.0230(0.59) \quad(-0.0553,0.1014)$

$0.2049(4.32)^{*} \quad(0.1085,0.3014)$

$0.0301(0.17) \quad(-0.3684,0.4249)$

$-0.0811(1.39) \quad(-0.1999,0.0376)$

$0.1732(3.04)^{*} \quad(0.0592,0.2872)$

$-0.0175(0.70) \quad(-0.0667,0.0315)$

$0.0961(1.68)^{* * *} \quad(-0.0191,0.2114)$

$0.1531(0.95) \quad(-0.2609,0.5673)$

$0.1089(0.98) \quad(-0.1206,0.3385)$

$0.0923(2.56)^{* *} \quad(0.0195,0.1652)$

t-statistics are reported in parentheses

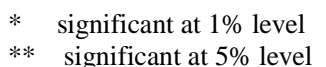

*** significant at $10 \%$ level 
Table 6: Analysis of Select Industry Composition Variables

Finance, Insurance, Real Estate

$\underline{\text { Region }}$

United States

Number of Counties

Alabama

Arkansas

California

Colorado

Florida

Georgia

Idaho

Illinois

Indiana

Iowa

Kansas

Kentucky

Louisiana

Michigan

Minnesota

Mississippi

Missouri

Montana

New York

North Carolina

North Dakota

Ohio

Oklahoma

Pennsylvania

South Carolina

South Dakota

Tennessee

Texas

Virginia

Washington

West Virginia

Wisconsin

\begin{tabular}{c}
2 SLS \\
\hline $0.0777(6.16)^{*}$ \\
\\
$0.2583(1.80)^{* * *}$ \\
$0.0464(0.43)$ \\
$0.0899(1.10)$ \\
$0.1091(1.08)$ \\
$0.0561(0.48)$ \\
$-0.0697(0.90)$ \\
$-0.3772(2.34)^{* *}$ \\
$0.1018(2.21)^{* *}$ \\
$-0.0022(0.03)$ \\
$0.1754(2.00)^{* *}$ \\
$0.0736(1.21)$ \\
$-0.0762(1.17)$ \\
$-0.4473(3.39)^{*}$ \\
$0.1029(1.01)$ \\
$0.0091(0.10)$ \\
$0.1244(0.70)$ \\
$-0.0002(0.01)$ \\
$0.1345(1.13)$ \\
$0.0759(0.77)$ \\
$-0.0858(0.79)$ \\
$0.7250(3.57)^{*}$ \\
$-0.0284(0.28)$ \\
$-0.0913(1.11)$ \\
$-0.0515(0.53)$ \\
$-0.1886(0.55)$ \\
$0.0758(0.72)$ \\
$0.2628(2.29)^{* *}$ \\
$0.1834(3.27)^{*}$ \\
$0.1706(1.39)$ \\
$-0.0328(0.12)$ \\
$0.1316(0.85)$ \\
$0.0355(0.47)$ \\
\end{tabular}

\section{$95 \%$ C.I. \\ $(0.0529,0.1024)$}

$(-0.0331,0.5498)$ $(-0.1728,0.2657)$ $(-0.0792,0.2591)$

$(-0.0972,0.3154)$

$(-0.1825,0.2947)$

$(-0.2224,0.0829)$

$(-0.7360,-0.0184)$

$(0.0100,0.1935)$

$(-0.1664,0.1618)$

$(0.0006,0.3502)$

$(-0.0475,0.1948)$

$(-0.2054,0.0528)$

$(-0.7167,-0.1778)$

$(-0.1025,0.3084)$

$(-0.1653,0.1835)$

$(-0.2349,0.4838)$

$(-0.1286,0.1282)$

$(-0.1123,0.3813)$

$(-0.1264,0.2783)$

$(-0.3040,0.1322)$

( $0.3014,1.1485)$

$(-0.2324,0.1756)$

$(-0,2578,0.0751)$

$(-0.2506,0.1476)$

$(-0.9331,0.5559)$

$(-0.1438,0.3010)$

$(0.0337,0.4921)$

$(0.0730,0.2939)$

$(-0.0761,0.4174)$

$(-0.7212,0.6555)$

$(-0.1904,0.4537)$

$(-0.1195,0.1907)$
Educational Services

$\frac{2 \text { SLS }}{-0.0334(3.90)^{*}} \quad \frac{95 \% \text { C.I. }}{(-0.0502,-0.0166)}$

$-0.1639(0.94) \quad(-0.5202,0.1924)$

$0.1168(1.52)$

$0.0332(0.29)$

$0.0650(0.96)$

$116(2.04)^{*}$

$0.0588(0.87)$

$(-0.6175,0.0522)$
$-1.93) * * * \quad(-0.2519,0.0240)$

$-0.1139(1.68)^{* * *} \quad(-0.2519,0.0240)$

$0.0233(0.48)$

$0.0254(0.39)$

$0.0084(0.10)$

$-0.0243(0.23)$

$-0.0878(1.40)$

$-0.2426(1.92)^{* * * *}$

$0.0243(0.39)$

$-0.0476(0.66)$

$-0.0830(0.51)$

$0.0923(0.84)$

$0.0900(0.60)$

$0.0345(0.35)$

$0.0991(1.24)$

$-0.1111(0.86)$

$0.1143(0.32)$

$0.0651(0.86)$

$0.0989(0.99)$

$-0.0347(0.80)$

$-0.1852(1.73)^{* * *}$

$0.2860(1.16)$

$-0.0645(0.47)$

$-0.0511(0.58)$
(-0.5362, -0.1223)

$(-0.1197,0.0730)$

$(-0.0923,0.0597)$

$(-0.1619,0.1787)$

$(-0.2397,0.1910)$

$(-0.2139,0.0382)$

$(-0.4973,0.0119)$

$(-0.1001,0.1487)$

$(-0.1274,0.31$

$(-0.1274,0.3121)$

$(-0.2223,04023)$

$(-0.1611,0.2303)$

$(-0.0618,0.2601)$

$(-0.3736,0.1513)$

$(-0.6737,0.9023)$

$(-0.0887,0.2189)$

$(-0.1007,0.2986)$

$(-0.1007,0.2986)$

$(-0.1207,0.0511)$

$(-0.4012,0.0306)$

$(-0.3458,0.9179)$

$(-0.3495,0.2203)$

$(-0.2306,0.1283)$
Entertainment \& Recreational Services

\begin{tabular}{|c|c|}
\hline 2 SLS & $95 \%$ C.I. \\
\hline $0.0477(2.89)^{*}$ & $(0.0153,0.0800)$ \\
\hline$-0.0954(0.32)$ & $(-0.7085,0.5175)$ \\
\hline$-0.0676(0.38)$ & $(-0.4296,0.2943)$ \\
\hline $0.1498(2.31)^{* *}$ & $(0.0161,0.2836)$ \\
\hline $0.0928(0.96)$ & $(-0.1057,0.2914)$ \\
\hline $0.1004(0.39)$ & $(-0.4225,0.6235)$ \\
\hline $0.2271(1.69)^{* * * *}$ & $(-0.0389,0.4932)$ \\
\hline$-0.2443(0.79)$ & $(-0.9308,0.4421)$ \\
\hline $0.3780(2.29)^{* *}$ & $(0.0481,0.7080)$ \\
\hline $0.1604(0.74)$ & $(-0.2726,0.5936)$ \\
\hline $0.2594(1.46)$ & $(-0.0948,0.6137)$ \\
\hline $0.0679(0.63)$ & $(-0.1477,0.2836)$ \\
\hline $0.1347(0.90)$ & $(-0.1622,0.4316)$ \\
\hline $0.4228(1.86)^{* * * *}$ & $(-0.0406,0.8864)$ \\
\hline$-0.2559(1.24)$ & $(-0.6713,0.1594)$ \\
\hline$-0.0524(0.29)$ & $(-0.4202,0.3153)$ \\
\hline $1.1467(3.18)^{*}$ & $(0.4218,1.8716)$ \\
\hline$-0.1223(0.67)$ & $(-0.4839,0.2392)$ \\
\hline $0.2268(1.27)$ & $(-0.1413,0.5949)$ \\
\hline $0.7624(2.40)^{* *}$ & $(0.1129,1.4120)$ \\
\hline $0.1475(0.81)$ & $(-0.2159,0.5108)$ \\
\hline $0.7627(3.37)^{*}$ & $(0.2908,1.2347)$ \\
\hline $0.2109(0.98)$ & $(-0.2194,0.6413)$ \\
\hline$-0.2212(1.01)$ & $(-0.6624,0.2199)$ \\
\hline $0.3957(1.12)$ & $(-0.3234,1.1149)$ \\
\hline$-0.2122(0.45)$ & $(-1.2037,0.8063)$ \\
\hline$-0.1032(0.56)$ & $(-0.4789,0.2724)$ \\
\hline$-0.3789(1.20)$ & $(-1.0087,0.2509)$ \\
\hline $0.0295(0.23)$ & $(-0.2228,0.2821)$ \\
\hline $0.0021(0.01)$ & $(-0.5651,0.5694)$ \\
\hline$-0.0475(0.07)$ & $(-1.8441,1.7489)$ \\
\hline $0.2850(1.50)$ & $(-0.1744,0.3641)$ \\
\hline $0.0321(0.15)$ & $(-0.4187,0.4835)$ \\
\hline
\end{tabular}

t-statistics are reported in parentheses

* $\quad$ significant at $1 \%$ level

** significant at 5\% level

*** significant at $10 \%$ level 
Figure 1:

95\% Confidence Intervals and Point Estimates of Within-State Asymptotic Convergence Rates

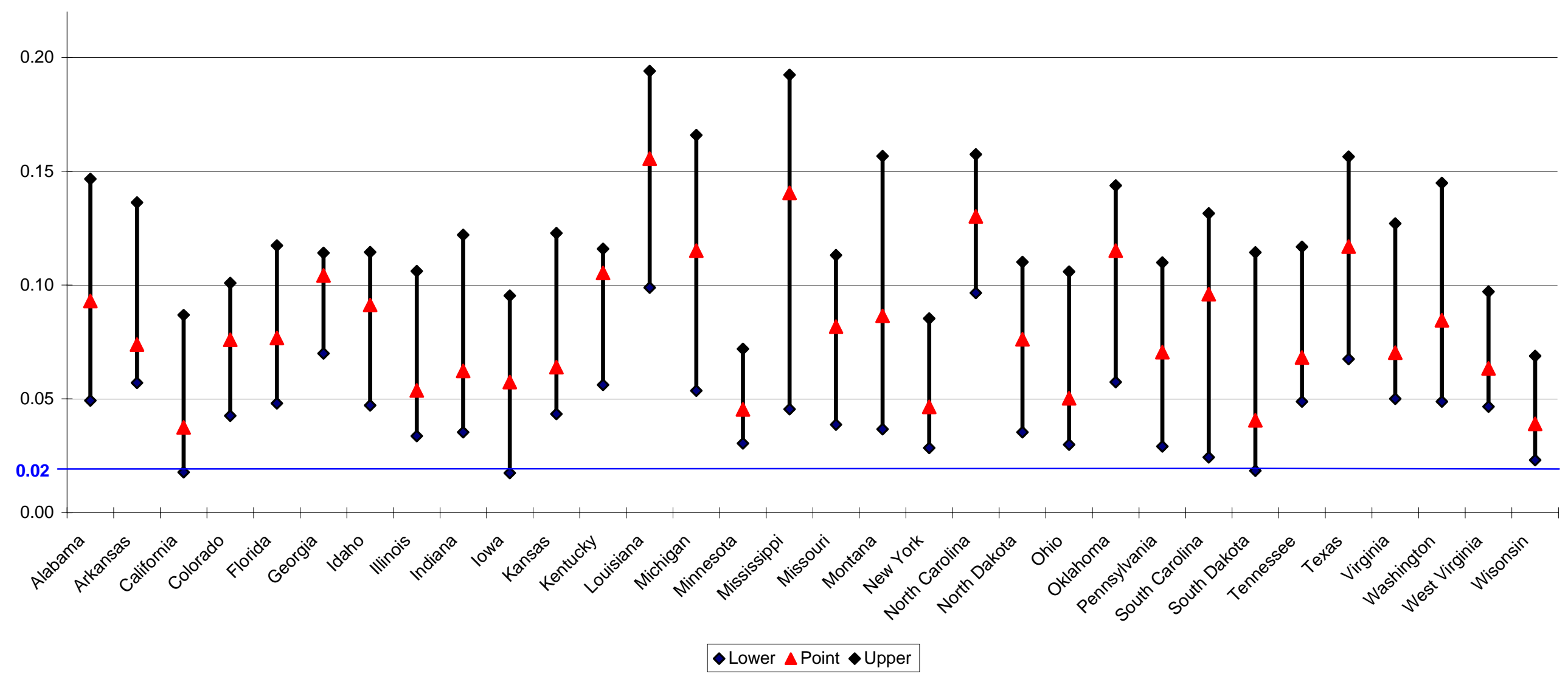




\section{Referee's Appendix: Inconsistency of OLS Estimates}

The method of ordinary least squares (OLS) could be used to infer the values of $\beta$ and $\gamma$ in equation (3). However, Evans (1997b) states that the OLS estimates

obtained from (3) are unlikely to be consistent. ${ }^{1}$ In order to demonstrate this inconsistency, Evans first specifies a general autoregressive moving average (ARMA) data-generating process for $y_{n t}$ :

$$
y_{n t}-a_{t}=\delta_{n}+\lambda_{n}\left(y_{n, t-1}-a_{t-1}\right)+\sum_{i=1}^{q} \theta_{n i} \varepsilon_{n, t-i}
$$

with

$$
\delta_{n}=\kappa+\xi_{n}^{\prime} x_{n}+\omega_{n}
$$

where $\varepsilon_{n t}$ is a zero-mean, covariance stationary error process independently distributed over time and across economies. The error term, $\varepsilon_{n t}$, is uncorrelated with $x_{n}, \lambda_{n}$ is an autoregressive parameter which lies on $(0,1]$, and $\theta_{n 0} \ldots \theta_{n q}$ satisfy the restriction $\theta_{n 0}=1$. As such, $y_{n t}-a_{t}$ will also have an autoregressive representation and will be covariance stationary if $\lambda_{n}<1$ or difference stationary if $\lambda_{n}=1$. The common time-specific effect experienced by every economy is represented by the term $a_{t}$. Evans assumes that $\Delta a_{t}$ is covariance stationary and independent of $\varepsilon_{n t}$.

The common trend $a_{t}$ for all the $y$ variables will be the sole catalyst of economic growth in all economies if $\lambda_{n}<1$. In this case, growth is exogenous and economies would follow a balanced-growth path. If $\lambda_{n}=1$, on the other hand, then economy $n$ will grow endogenously since $y_{n t}$ diverges from $a_{t}$ and the $y$ variables of all remaining economies. The parameter $\delta_{n}$ controls for the relative height of economy $n$ 's balanced growth path if all the $\lambda \mathrm{s}$ are less than one. If $\lambda_{n}=1$, then $\delta_{n}$ controls for economy $n$ 's

\footnotetext{
1 This section borrows heavily from Evans (1997b), which can be consulted for further details.
} 
relative growth rate. The error term $\omega_{n}$ measures the portion of $\delta_{n}$ that is not explained by $x_{n}$. This error term is assumed to be uncorrelated with $x_{n}$. The inequality $\lambda_{n}<1$ will hold for an economy described by the neoclassical growth model.

Solving equation (1A) backward from year $T$ to year 0 , substituting from equation $(2 \mathrm{~A})$, and rearranging produces

$$
\begin{aligned}
& g_{n}=\alpha_{n}+\beta_{n} y_{n 0}+\gamma_{n}^{\prime} x_{n}-\frac{\beta_{n} \omega_{n}}{1-\gamma_{n}}+\frac{1}{T} \sum_{i=0}^{T-1} \lambda_{n}^{i}\left(\sum_{j=0}^{\min [i, q]} \lambda_{n}^{-j} \theta_{n j}\right) \varepsilon_{n, T-i} \\
& +\left(\frac{\lambda_{n}^{T}}{T}\right)_{i=0}^{q-1} \lambda_{n}^{i}\left(\sum_{j=i+1}^{q} \lambda_{n}^{-j} \theta_{n j}\right) \varepsilon_{n,-i}
\end{aligned}
$$

where $\beta_{n}=\frac{\lambda_{n}^{T}-1}{T}, \gamma_{n}=\frac{-\beta_{n} \xi_{n}}{1-\lambda_{n}}$, and $\alpha_{n}=\frac{a_{T}-a_{0}}{T-\beta_{n}\left(\frac{a_{0}+\kappa}{1-\lambda_{n}}\right)}$. If $\beta_{n}<0$, then economy $n$ grows exogenously $\left(\lambda_{n}<1\right)$. On the other hand, if $\beta_{n}=0$, then economy $n$ grows endogenously $\left(\lambda_{n}=1\right)$.

Now consider a special case in which every intercept $\delta_{n}$ is completely explained by the county characteristics included in $x_{n}\left(\omega_{n}=0, \forall n\right)$ and every series $y_{n t}-a_{t}$ is a first-order auto-regression $(q=0)$. Under these restrictions equation (3A) reduces to:

$$
g_{n}=\alpha_{n}+\beta_{n} y_{n 0}+\gamma_{n}^{\prime} x_{n}+\frac{1}{T} \sum_{i=0}^{T-1} \lambda_{n}^{i} \varepsilon_{n, T-i}
$$

The estimator for $\hat{\beta}$ can then be obtained in two steps. First, regress $y_{n 0}$ on an intercept and $x_{n}$ to obtain the residual $r_{n}$ and then regress $g_{n}$ on $r_{n}$. (This is simply the OLS estimator of $\beta$.) Each term in $\frac{1}{T} \sum_{i=0}^{T-1} \lambda_{n}^{i} \varepsilon_{n, T-i}$ is uncorrelated with the intercept, $y_{n}, x_{n}$ and the residual $r_{n}$. As a result, one has 


$$
p \lim _{N \rightarrow \infty} \hat{\beta}=\frac{p \lim _{N \rightarrow \infty} \frac{1}{N} \sum_{n=1}^{N} \alpha_{n} r_{n}+p \lim _{N \rightarrow \infty} \frac{1}{N} \sum_{n=1}^{N} \beta_{n} r_{n} y_{n}+p \lim _{N \rightarrow \infty} \frac{1}{N} \sum_{n=1}^{N} \gamma_{n}^{\prime} r_{n} x_{n}}{p \lim \frac{1}{N} \sum_{n \rightarrow 1}^{N} r_{n}^{2}}
$$

Making further assumptions that $\alpha_{n}$ is uncorrelated with $r_{n}, \beta_{n}$ is uncorrelated with $r_{n} y_{n}$, and $\gamma_{n}$ is uncorrelated with $r_{n} x_{n}$, equation (5A) leads to

$$
p \lim _{N \rightarrow \infty} \hat{\beta}=\frac{p \lim _{N \rightarrow \infty} \frac{1}{N} \sum_{n=1}^{N} \beta_{n} r_{n}^{2}}{p \lim \frac{1}{N} \sum_{n=1}^{N} r_{n}^{2}}
$$

The probability limit of the OLS estimator is then a weighted average of the economy specific $\beta_{n}$ s. It is a consistent estimator of that weighted average. ${ }^{2}$

But what if the assumption that every intercept $\delta_{n}$ is completely explained by $x_{n}$ and also the assumption that every series $y_{n t}-a_{t}$ is a first-order auto-regression, are relaxed? Relaxing these assumptions, and imposing the additional restriction that the $\lambda s$ and $\xi_{s}$ and, as a result, the $\beta s$ and $\gamma s$ are identical across all economies (for the simplicity of the exposition), (3A) can be re-written as

$$
\begin{aligned}
& g_{n}=\alpha+\beta y_{n 0}+\gamma^{\prime} x_{n}-\frac{\beta \omega_{n}}{1-\gamma}+\frac{1}{T} \sum_{i=0}^{T-1} \lambda^{i}\left(\sum_{j=0}^{\min [i, q]} \lambda^{-j} \theta_{n j}\right) \varepsilon_{n, T-i} \\
& +\left(\frac{\lambda^{T}}{T}\right) \sum_{i=0}^{q-1} \lambda^{i}\left(\sum_{j=i+1}^{q} \lambda^{-j} \theta_{n j}\right) \varepsilon_{n,-i}
\end{aligned}
$$

2 Strictly speaking, even for this restrictive case, an OLS estimate less than unity does not mean that all the economies in the sample conform to the neoclassical growth model. Rather, it would mean that enough economies conform, so that the weighted average is less than unity. It would mean, therefore, that exogenous growth is the predominant case across the sample. 
where $\beta=\frac{\lambda^{T}-1}{T}, \gamma=\frac{-\beta \xi}{1-\lambda}$, and $\alpha=\frac{a_{T}-a_{0}}{T-\beta\left(\frac{a_{0}+\kappa}{1-\lambda}\right)}$. Applying the same steps to equation (6A) yields

$$
p \lim _{N \rightarrow \infty} \hat{\beta}=\beta+\frac{(\Phi+\Psi)}{p \lim _{N \rightarrow \infty} \frac{1}{N} \sum_{n=1}^{N} r_{n}^{2}}
$$

where $\Phi=\frac{\lambda^{T}}{T} p \lim _{N \rightarrow \infty} \frac{I}{N} \sum_{n=1}^{N}\left[\sum_{i=0}^{q-1} \lambda^{i}\left(\sum \lambda^{-j} \theta_{n, j+i+1}\right) r_{n} \varepsilon_{n,-i}\right]$ and $\Psi=-\frac{\beta}{1-\lambda} \lim _{N \rightarrow \infty} \frac{1}{N} \sum r_{n} \omega_{n}$. As a result, equation (8A) implies that $p_{N \rightarrow \infty} \hat{\beta}$ differs from $\beta$ if either $q>0\left(y_{n t}-a_{t}\right.$ is not a first-order AR process) or the cross-sectional variance of $\omega_{n}$ is positive (not all cross-sectional heterogeneity is accounted for). In other words, the OLS estimator is inconsistent unless (a) the log of income per capita has an identical first-order AR representation across economies, and (b) all cross-section heterogeneity is controlled for.

Evans shows that the resulting bias from $q>0$ is likely to be negligible in practice but the bias resulting from a positive cross-sectional variance for $\omega_{n}$ can be substantial. This is essentially an omitted variable bias. Evans demonstrates that

$$
p \lim _{N \rightarrow \infty} \hat{\beta}=\left\lfloor\frac{\operatorname{var}(y \mid x, \omega)}{\operatorname{var}(y \mid x)}\right\rfloor \beta
$$

and

$$
p \lim _{N \rightarrow \infty} \hat{\gamma}=\left\lfloor\frac{\operatorname{var}(y \mid x, \omega)}{\operatorname{var}(y \mid x)}\right\rfloor \gamma .
$$

The bracketed portions in equations (9A) and (10A) are the ratio of the cross-sectional variance of $y_{n 0}$ conditional on both $x_{n}$ and $\omega_{n}$ to the cross-sectional variance of $y_{n 0}$ on 
$x_{n}$. As such, $\hat{\beta}$ and $\hat{\gamma}$ will be biased towards zero unless the $x s$ are able to control for a large portion of the cross-economy variation in the $y s$.

The intuition here is that if a large portion of the growth of per capita income is explained by variables left out of the OLS regression, then the estimate of the convergence effect will be biased. In general, omitted variable bias can be either positive or negative. However, in this case, theoretically, the bias is negative. Evans (1997b, Tables on p. 11 and p. 15) estimates $\beta$ for Mankiw, et al.'s (1992) international data using both the OLS, which yields inconsistent estimates, and the 2SLS approach (as outlined in section 2), which yields consistent estimates of both $\beta$ and $\gamma$. He finds that the 2SLS estimate implies a conditional convergence rate between 4 to 5 times as large as the OLS estimate. The bias produced by the OLS in this case, therefore, is substantial. 
Referee Appendix Table 1: Entire United States

\begin{tabular}{|c|c|c|c|c|c|c|c|c|c|c|}
\hline \multirow[b]{2}{*}{$\underline{\text { RHS Variables }^{1}}$} & \multicolumn{2}{|c|}{ __Alabama } & \multicolumn{2}{|c|}{ __ Arkansas } & \multicolumn{2}{|c|}{ _California } & \multicolumn{2}{|c|}{ Colorado } & \multicolumn{2}{|c|}{ Florida } \\
\hline & $\underline{\text { OLS }}$ & $\underline{2 S L S}$ & $\underline{\text { OLS }}$ & $\underline{2 S L S}$ & $\underline{\text { OLS }}$ & $\underline{2 S L S}$ & $\underline{\text { OLS }}$ & $\underline{2 S L S}$ & $\underline{\text { OLS }}$ & $\underline{2 S L S}$ \\
\hline Constant & $\begin{array}{l}0.0572 \\
(0.31)\end{array}$ & $\begin{array}{l}0.1399 \\
(0.92)\end{array}$ & $\begin{array}{l}0.0689 \\
(0.48)\end{array}$ & $\begin{array}{l}0.1255 \\
(0.86)\end{array}$ & $\begin{array}{l}0.0573 \\
(0.25)\end{array}$ & $\begin{array}{l}0.0449 \\
(0.21)\end{array}$ & $\begin{array}{l}0.1971 \\
(1.74)^{* * *}\end{array}$ & $\begin{array}{l}0.3827 \\
(3.25)^{*}\end{array}$ & $\begin{array}{l}0.0092 \\
(0.04)\end{array}$ & $\begin{array}{l}0.1625 \\
(0.74)\end{array}$ \\
\hline $\begin{array}{l}\text { Log } 1970 \text { per capita } \\
\text { income }^{2}\end{array}$ & $\begin{array}{l}-0.0251 \\
(2.38)^{* *}\end{array}$ & $\begin{array}{l}-0.0334 \\
(20.49)^{*}\end{array}$ & $\begin{array}{l}-0.0267 \\
(4.48)^{*}\end{array}$ & $\begin{array}{l}-0.0384 \\
(22.08)^{*}\end{array}$ & $\begin{array}{l}-0.0261 \\
(2.50)^{* *}\end{array}$ & $\begin{array}{l}-0.0235 \\
(4.87)^{*}\end{array}$ & $\begin{array}{l}-0.0133 \\
(2.53)^{* *}\end{array}$ & $\begin{array}{l}-0.0318 \\
(13.41)^{*}\end{array}$ & $\begin{array}{l}-0.0190 \\
(2.06)^{* *}\end{array}$ & $\begin{array}{l}-0.0318 \\
(14.98)^{*}\end{array}$ \\
\hline Age: $5-13$ years & $\begin{array}{l}0.2200 \\
(1.03)\end{array}$ & $\begin{array}{l}0.1991 \\
(0.95)\end{array}$ & $\begin{array}{l}0.2602 \\
(1.33)\end{array}$ & $\begin{array}{l}0.3321 \\
(1.67)^{* * *}\end{array}$ & $\begin{array}{l}0.1965 \\
(0.69)\end{array}$ & $\begin{array}{l}0.1819 \\
(0.67)\end{array}$ & $\begin{array}{l}-0.0602 \\
(0.47)\end{array}$ & $\begin{array}{l}-0.0538 \\
(0.36)\end{array}$ & $\begin{array}{l}0.0924 \\
(0.36)\end{array}$ & $\begin{array}{l}0.0723 \\
(0.28)\end{array}$ \\
\hline Age: $14-17$ years & $\begin{array}{l}-0.0369 \\
(0.17)\end{array}$ & $\begin{array}{l}-0.0617 \\
(0.29)\end{array}$ & $\begin{array}{l}0.1106 \\
(0.81)\end{array}$ & $\begin{array}{l}0.1081 \\
(0.77)\end{array}$ & $\begin{array}{l}0.1049 \\
(0.42)\end{array}$ & $\begin{array}{l}0.1002 \\
(0.41)\end{array}$ & $\begin{array}{l}-0.0111 \\
(0.11)\end{array}$ & $\begin{array}{l}-0.0387 \\
(0.33)\end{array}$ & $\begin{array}{l}0.1892 \\
(0.80)\end{array}$ & $\begin{array}{l}0.1257 \\
(0.53)\end{array}$ \\
\hline Age: $18-64$ years & $\begin{array}{l}0.1144 \\
(0.62)\end{array}$ & $\begin{array}{l}0.0978 \\
(0.54)\end{array}$ & $\begin{array}{l}0.1522 \\
(1.20)\end{array}$ & $\begin{array}{l}0.1798 \\
(1.38)\end{array}$ & $\begin{array}{l}0.1497 \\
(0.69)\end{array}$ & $\begin{array}{l}0.1393 \\
(0.66)\end{array}$ & $\begin{array}{l}-0.1682 \\
(1.42)\end{array}$ & $\begin{array}{l}-0.1779 \\
(1.28)\end{array}$ & $\begin{array}{l}0.1105 \\
(0.51)\end{array}$ & $\begin{array}{l}0.0593 \\
(0.27)\end{array}$ \\
\hline Age: $65+$ & $\begin{array}{l}0.1441 \\
(0.89)\end{array}$ & $\begin{array}{l}0.1131 \\
(0.73)\end{array}$ & $\begin{array}{l}0.1571 \\
(1.19)\end{array}$ & $\begin{array}{l}0.1740 \\
(1.28)\end{array}$ & $\begin{array}{l}0.1762 \\
(0.85)\end{array}$ & $\begin{array}{l}0.1652 \\
(0.84)\end{array}$ & $\begin{array}{l}-0.0661 \\
(0.78)\end{array}$ & $\begin{array}{l}-0.0526 \\
(0.53)\end{array}$ & $\begin{array}{l}0.0873 \\
(0.47)\end{array}$ & $\begin{array}{l}0.0466 \\
(0.25)\end{array}$ \\
\hline Blacks & $\begin{array}{l}-0.0233 \\
(1.61)\end{array}$ & $\begin{array}{l}-0.0264 \\
(1.89)^{* * *}\end{array}$ & $\begin{array}{l}0.0006 \\
(0.07)\end{array}$ & $\begin{array}{l}0.0023 \\
(0.27)\end{array}$ & $\begin{array}{l}0.0035 \\
(0.11)\end{array}$ & $\begin{array}{l}0.0015 \\
(0.05)\end{array}$ & $\begin{array}{l}-0.1083 \\
(0.94)\end{array}$ & $\begin{array}{l}-0.1384 \\
(1.03)\end{array}$ & $\begin{array}{l}0.0189 \\
(1.17)\end{array}$ & $\begin{array}{l}0.0207 \\
(1.26)\end{array}$ \\
\hline Hispanic & $\begin{array}{l}-0.0947 \\
(0.24)\end{array}$ & $\begin{array}{l}-0.2311 \\
(0.66)\end{array}$ & $\begin{array}{l}0.1775 \\
(0.67)\end{array}$ & $\begin{array}{l}0.1111 \\
(0.41)\end{array}$ & $\begin{array}{l}0.0191 \\
(1.11)\end{array}$ & $\begin{array}{l}0.0193 \\
(1.15)\end{array}$ & $\begin{array}{l}-0.0005 \\
(0.06)\end{array}$ & $\begin{array}{l}-0.0007 \\
(0.07)\end{array}$ & $\begin{array}{l}0.0315 \\
(0.66)\end{array}$ & $\begin{array}{l}0.0397 \\
(0.82)\end{array}$ \\
\hline Education: 9-11 years & $\begin{array}{c}0.0819 \\
(2.03)^{* * *}\end{array}$ & $\begin{array}{c}0.0832 \\
(2.07)^{* *}\end{array}$ & $\begin{array}{l}-0.0188 \\
(0.63)\end{array}$ & $\begin{array}{l}-0.0223 \\
(0.73)\end{array}$ & $\begin{array}{l}-0.0676 \\
(1.00)\end{array}$ & $\begin{array}{l}-0.0673 \\
(1.02)\end{array}$ & $\begin{array}{c}0.1037 \\
(2.53)^{* *}\end{array}$ & $\begin{array}{c}0.1171 \\
(2.44)^{* *}\end{array}$ & $\begin{array}{l}-0.0211 \\
(0.35)\end{array}$ & $\begin{array}{l}-0.0045 \\
(0.07)\end{array}$ \\
\hline Education: H.S. diploma & $\begin{array}{l}0.0077 \\
(0.16)\end{array}$ & $\begin{array}{c}0.0832 \\
(2.07)^{* *}\end{array}$ & $\begin{array}{l}0.0073 \\
(0.24)\end{array}$ & $\begin{array}{l}0.0153 \\
(0.49)\end{array}$ & $\begin{array}{l}-0.0217 \\
(0.60)\end{array}$ & $\begin{array}{l}-0.0212 \\
(0.60)\end{array}$ & $\begin{array}{l}0.0226 \\
(0.81)\end{array}$ & $\begin{array}{c}0.0654 \\
(2.23)^{* *}\end{array}$ & $\begin{array}{l}0.0614 \\
(0.91)\end{array}$ & $\begin{array}{l}0.0649 \\
(0.95)\end{array}$ \\
\hline Education: Some college & $\begin{array}{l}0.0998 \\
(1.08)\end{array}$ & $\begin{array}{l}0.1229 \\
(1.41)\end{array}$ & $\begin{array}{l}0.0355 \\
(0.56)\end{array}$ & $\begin{array}{l}0.0492 \\
(0.75)\end{array}$ & $\begin{array}{l}0.0494 \\
(0.72)\end{array}$ & $\begin{array}{l}0.0513 \\
(0.77)\end{array}$ & $\begin{array}{l}0.1039 \\
(1.78)^{* * *}\end{array}$ & $\begin{array}{l}0.0600 \\
(0.90)\end{array}$ & $\begin{array}{l}0.1688 \\
(1.59)\end{array}$ & $\begin{array}{l}0.1813 \\
(1.69)^{* * *}\end{array}$ \\
\hline Education: Bachelor + & $\begin{array}{l}0.0415 \\
(0.70)\end{array}$ & $\begin{array}{l}0.0448 \\
(0.77)\end{array}$ & $\begin{array}{l}0.1025 \\
(1.39)\end{array}$ & $\begin{array}{l}0.1188 \\
(1.56)\end{array}$ & $\begin{array}{c}0.1063 \\
(2.14)^{* *}\end{array}$ & $\begin{array}{c}0.1003 \\
(2.36)^{* *}\end{array}$ & $\begin{array}{c}0.0621 \\
(1.69)^{* * *}\end{array}$ & $\begin{array}{l}0.1178 \\
(3.03)^{*}\end{array}$ & $\begin{array}{l}0.0534 \\
(0.57)\end{array}$ & $\begin{array}{l}0.1094 \\
(1.28)\end{array}$ \\
\hline Housing & $\begin{array}{l}0.0000 \\
(0.39)\end{array}$ & $\begin{array}{l}0.0000 \\
(0.66)\end{array}$ & $\begin{array}{l}0.0000 \\
(0.47)\end{array}$ & $\begin{array}{l}0.0000 \\
(0.52)\end{array}$ & $\begin{array}{l}-0.0000 \\
(0.63)\end{array}$ & $\begin{array}{l}-0.0000 \\
(0.68)\end{array}$ & $\begin{array}{l}0.0000 \\
(1.93)^{* * * *}\end{array}$ & $\begin{array}{c}0.0000 \\
(2.06)^{* *}\end{array}$ & $\begin{array}{l}-0.0000 \\
(0.15)\end{array}$ & $\begin{array}{l}0.0000 \\
(0.11)\end{array}$ \\
\hline $\begin{array}{l}\text { Federal government } \\
\text { employment }\end{array}$ & $\begin{array}{l}0.0232 \\
(0.40)\end{array}$ & $\begin{array}{l}0.0391 \\
(0.72)\end{array}$ & $\begin{array}{l}-0.0060 \\
(0.13)\end{array}$ & $\begin{array}{l}-0.0142 \\
(0.29)\end{array}$ & $\begin{array}{l}0.0357 \\
(1.22)\end{array}$ & $\begin{array}{l}0.0352 \\
(1.23)\end{array}$ & $\begin{array}{l}-0.0207 \\
(0.61)\end{array}$ & $\begin{array}{l}-0.0609 \\
(1.69) * * *\end{array}$ & $\begin{array}{l}0.0471 \\
(0.64)\end{array}$ & $\begin{array}{l}0.0280 \\
(0.38)\end{array}$ \\
\hline $\begin{array}{l}\text { State government } \\
\text { employment }\end{array}$ & $\begin{array}{l}-0.0129 \\
(0.27)\end{array}$ & $\begin{array}{l}-0.0131 \\
(0.27)\end{array}$ & $\begin{array}{l}-0.0220 \\
(0.61)\end{array}$ & $\begin{array}{l}-0.0408 \\
(1.13)\end{array}$ & $\begin{array}{l}0.0350 \\
(0.86)\end{array}$ & $\begin{array}{l}0.0331 \\
(0.84)\end{array}$ & $\begin{array}{l}-0.0223 \\
(0.60)\end{array}$ & $\begin{array}{l}-0.0605 \\
(1.66)^{* * *}\end{array}$ & $\begin{array}{l}0.0122 \\
(0.22)\end{array}$ & $\begin{array}{l}0.0049 \\
(0.09)\end{array}$ \\
\hline $\begin{array}{l}\text { Local government } \\
\text { employment }\end{array}$ & $\begin{array}{l}0.0348 \\
(0.64)\end{array}$ & $\begin{array}{l}0.0379 \\
(0.71)\end{array}$ & $\begin{array}{l}-0.0443 \\
(1.05)\end{array}$ & $\begin{array}{l}-0.0392 \\
(0.90)\end{array}$ & $\begin{array}{l}0.0506 \\
(0.75)\end{array}$ & $\begin{array}{l}0.0462 \\
(0.72)\end{array}$ & $\begin{array}{l}-0.0043 \\
(0.14)\end{array}$ & $\begin{array}{l}-0.0215 \\
(0.61)\end{array}$ & $\begin{array}{l}-0.0438 \\
(0.51)\end{array}$ & $\begin{array}{l}-0.0244 \\
(0.28)\end{array}$ \\
\hline Self-employment & $\begin{array}{l}-0.0512 \\
(1.11)\end{array}$ & $\begin{array}{l}-0.0622 \\
(1.43)\end{array}$ & $\begin{array}{l}0.0045 \\
(0.16)\end{array}$ & $\begin{array}{l}0.0019 \\
(0.07)\end{array}$ & $\begin{array}{l}-0.0404 \\
(0.66)\end{array}$ & $\begin{array}{l}-0.0364 \\
(0.63)\end{array}$ & $\begin{array}{l}0.0286 \\
(0.93)\end{array}$ & $\begin{array}{l}-0.0032 \\
(0.09)\end{array}$ & $\begin{array}{l}0.0673 \\
(1.43)\end{array}$ & $\begin{array}{l}0.0721 \\
(1.51)\end{array}$ \\
\hline Agriculture & $\begin{array}{l}0.0725 \\
(0.96)\end{array}$ & $\begin{array}{l}0.0881 \\
(1.22)\end{array}$ & $\begin{array}{l}0.0285 \\
(0.44)\end{array}$ & $\begin{array}{l}0.0578 \\
(0.88)\end{array}$ & $\begin{array}{l}0.0350 \\
(0.82)\end{array}$ & $\begin{array}{l}0.0295 \\
(0.83)\end{array}$ & $\begin{array}{l}0.0001 \\
(0.01)\end{array}$ & $\begin{array}{l}0.0193 \\
(0.38)\end{array}$ & $\begin{array}{l}0.0431 \\
(0.54)\end{array}$ & $\begin{array}{l}0.0491 \\
(0.61)\end{array}$ \\
\hline Communications & $\begin{array}{l}-0.0803 \\
(1.37)\end{array}$ & $\begin{array}{l}-0.0846 \\
(1.45)\end{array}$ & $\begin{array}{l}-0.0022 \\
(0.02)\end{array}$ & $\begin{array}{l}0.0216 \\
(0.23)\end{array}$ & $\begin{array}{l}-0.0298 \\
(0.44)\end{array}$ & $\begin{array}{l}-0.0295 \\
(0.44)\end{array}$ & $\begin{array}{l}-0.1039 \\
(1.45)\end{array}$ & $\begin{array}{l}-0.1122 \\
(1.33)\end{array}$ & $\begin{array}{l}-0.1259 \\
(1.13)\end{array}$ & $\begin{array}{l}-0.1377 \\
(1.22)\end{array}$ \\
\hline Construction & $\begin{array}{l}0.0927 \\
(1.17)\end{array}$ & $\begin{array}{l}0.1140 \\
(1.54)\end{array}$ & $\begin{array}{l}0.0737 \\
(1.22)\end{array}$ & $\begin{array}{l}0.0924 \\
(1.50)\end{array}$ & $\begin{array}{l}0.1033 \\
(2.28)^{* *}\end{array}$ & $\begin{array}{l}0.1032 \\
(2.32)^{* *}\end{array}$ & $\begin{array}{l}-0.0091 \\
(0.22)\end{array}$ & $\begin{array}{l}-0.0268 \\
(0.57)\end{array}$ & $\begin{array}{l}0.0951 \\
(1.38)\end{array}$ & $\begin{array}{l}0.1095 \\
(1.85)^{* * *}\end{array}$ \\
\hline $\begin{array}{l}\text { Finance, insurance } \\
\& \text { real estate }\end{array}$ & $\begin{array}{l}0.2331 \\
(1.58)\end{array}$ & $\begin{array}{l}0.2583 \\
(1.80)^{* * *}\end{array}$ & $\begin{array}{l}0.0273 \\
(0.26)\end{array}$ & $\begin{array}{l}0.0464 \\
(0.43)\end{array}$ & $\begin{array}{l}0.0947 \\
(1.10)\end{array}$ & $\begin{array}{l}0.0899 \\
(1.10)\end{array}$ & $\begin{array}{l}0.1735 \\
(1.98)^{* *}\end{array}$ & $\begin{array}{l}0.1091 \\
(2.08)^{* *}\end{array}$ & $\begin{array}{l}0.0652 \\
(0.56)\end{array}$ & $\begin{array}{l}0.0561 \\
(0.48)\end{array}$ \\
\hline $\begin{array}{l}\text { Manufacturing - } \\
\text { durables }\end{array}$ & $\begin{array}{l}0.0451 \\
(0.74)\end{array}$ & $\begin{array}{l}0.0551 \\
(0.92)\end{array}$ & $\begin{array}{l}0.0424 \\
(0.68)\end{array}$ & $\begin{array}{l}0.0607 \\
(0.95)\end{array}$ & $\begin{array}{l}0.0442 \\
(1.35)\end{array}$ & $\begin{array}{l}0.0426 \\
(1.36)\end{array}$ & $\begin{array}{l}0.0060 \\
(0.13)\end{array}$ & $\begin{array}{l}-0.0204 \\
(0.37)\end{array}$ & $\begin{array}{l}0.0647 \\
(0.86)\end{array}$ & $\begin{array}{l}0.0660 \\
(0.87)\end{array}$ \\
\hline
\end{tabular}

1 All RHS variables are initial values from 1970.

2 All dollar values are in real 1992 dollars. 
Referee Appendix Table 1: Entire United States (continued)

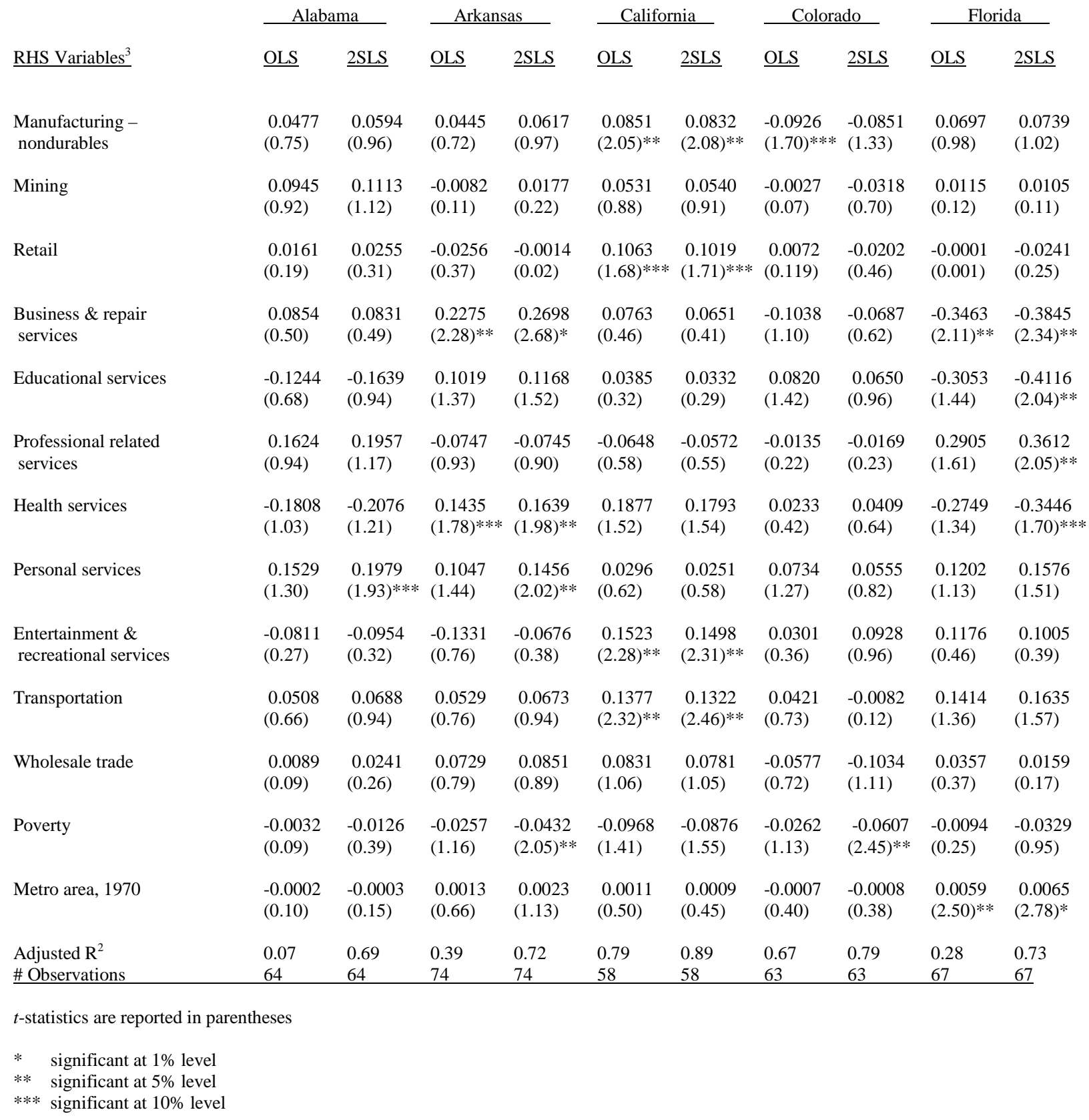

\footnotetext{
3 All RHS variables are initial values from 1970.
} 
RHS Variables $^{4}$

Constant

Log 1970 per capita income ${ }^{5}$

Age: 5-13 years

Age: $14-17$ years

Age: 18-64 years

Age: $65+$

Blacks

Hispanic

Education: 9-11 years

Education: H.S. diploma

Education: Some college

Education: Bachelor +

Housing

Federal government employment

State government

employment

Local government employment

Self-employment

Agriculture

Communications

Construction

Finance, insurance $\&$ real estate

Manufacturing durables

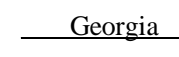

\section{Ots}

$\begin{array}{cccccccccc}0.0174 & 0.4666 & 0.4294 & 0.4303 & 0.2753 & 0.3083 & 0.1449 & 0.3661 & 0.0239 & 0.0247 \\ (2.11)^{* *} & (7.37)^{*} & (2.41)^{* *} & (2.81)^{* *} & (2.62)^{* *} & (3.59)^{*} & (1.18) & (3.00)^{*} & (0.21) & (0.23) \\ & & & & & & & & & \end{array}$

$\begin{array}{llllllllll}-0.0171 & -0.0367 & -0.0403 & -0.0405 & -0.0255 & -0.0281 & -0.0061 & -0.0299 & -0.0288 & -0.0289\end{array}$

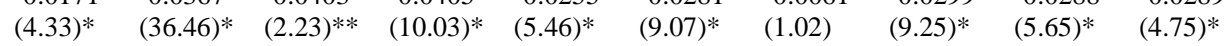

$\begin{array}{llllllllll}-0.0867 & -0.1559 & 0.1599 & 0.1614 & 0.0036 & -0.0052 & 0.1574 & 0.0439 & 0.2522 & 0.2521\end{array}$

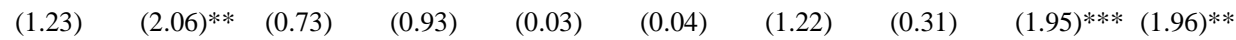

$\begin{array}{llllllllll}-0.0853 & -0.1866 & 0.0131 & 0.0143 & -0.0231 & -0.0345 & 0.0671 & 0.0245 & 0.1254 & 0.1256\end{array}$

$\begin{array}{lllllllll}(1.09) & (2.26)^{* *} & (0.06) & (0.08) & (0.26) & (0.41) & (0.59) & (0.19) & (1.24)\end{array}$

$\begin{array}{llllllllll}-0.0311 & -0.1140 & 0.2249 & 0.2265 & -0.0141 & -0.0233 & 0.0302 & -0.0353 & 0.1469 & 0.1469\end{array}$

$\begin{array}{llllllll}(0.56) & (1.98)^{* *} & (1.32) & (2.05)^{* * *}(0.15) & (0.26) & (0.32) & (0.34) & (1.69)^{* * *}(1.70)^{* * *}\end{array}$

$\begin{array}{llllllllll}0.0154 & -0.0573 & 0.0900 & 0.0912 & -0.0939 & -0.1016 & 0.0689 & -0.0281 & 0.1092 & 0.1091\end{array}$

$\begin{array}{lllllllll}(0.30) & (1.08) & (0.59) & (0.79) & (1.12) & (1.23) & (0.78) & (0.30) & (1.19)\end{array}$

$\begin{array}{llllllllll}-0.0020 & -0.0055 & -0.1843 & -0.1828 & -0.0054 & -0.0057 & -0.0300 & -0.0288 & -0.1568 & -0.1571\end{array}$

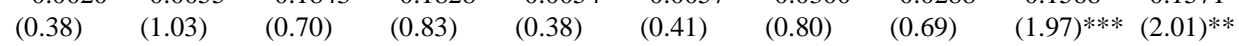

$\begin{array}{llllllllll}-0.0184 & -0.1481 & 0.0102 & 0.0105 & -0.0052 & -0.0018 & 0.0201 & 0.0393 & 0.1651 & 0.1652\end{array}$

$\begin{array}{llllllllll}(0.14) & (1.07) & (0.15) & (0.18) & (0.10) & (0.04) & (0.28) & (0.49) & (1.62) & (1.64)\end{array}$

$\begin{array}{llllllllll}-0.0094 & 0.0087 & 0.0609 & 0.0612 & -0.0592 & -0.0587 & -0.0463 & -0.0333 & -0.0314 & -0.0314\end{array}$

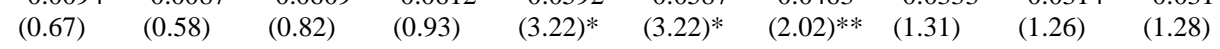

$\begin{array}{llllllllll}0.0028 & 0.0103 & 0.0893 & 0.0893 & -0.0166 & -0.0149 & -0.0441 & -0.0220 & -0.0003 & -0.0003\end{array}$

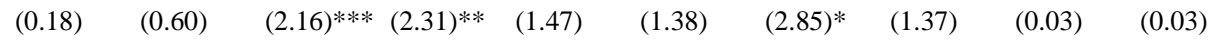

$\begin{array}{llllllllll}0.0793 & 0.0715 & -0.0053 & -0.0052 & 0.0255 & 0.0280 & 0.1167 & 0.1129 & 0.0155 & 0.0157\end{array}$

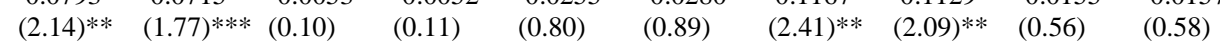

$\begin{array}{llllllllll}0.0031 & 0.0279 & 0.0643 & 0.0656 & 0.0449 & 0.0495 & -0.0369 & 0.0406 & -0.0368 & -0.0369\end{array}$

$\begin{array}{lllllllll}(0.11) & (0.90) & (0.44) & (0.65) & (1.40) & (1.61) & (0.76) & (0.82) & (1.19)\end{array}$

$\begin{array}{llllllllll}0.0000 & 0.0000 & 0.0000 & 0.0000 & 0.0000 & 0.0000 & -0.0000 & -0.000 & 0.0000 & 0.0000\end{array}$

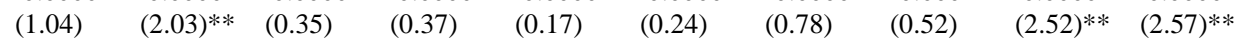

$\begin{array}{llllllllll}0.0166 & -0.0100 & -0.1098 & -0.1102 & 0.0409 & 0.0405 & -0.0607 & -0.0968 & 0.0540 & 0.0541\end{array}$

$\begin{array}{lllllllll}(0.50) & (0.28) & (1.60) & (1.94)^{* * *} & (1.24) & (1.24) & (1.16) & (2.03)^{* *} & (1.42)\end{array}$

$\begin{array}{llllllllll}0.0197 & 0.0035 & 0.0360 & 0.0364 & -0.0087 & -0.0095 & 0.0239 & -0.0043 & 0.0456 & -0.0457\end{array}$

$\begin{array}{lllllllllll}(0.90) & (0.15) & (0.79) & (1.10) & (0.46) & (0.51) & (1.05) & (0.18) & (2.30)^{* *} & (2.32)^{* *}\end{array}$

$\begin{array}{llllllllll}0.0377 & 0.0144 & 0.0272 & 0.0280 & -0.0047 & -0.0009 & -0.0474 & -0.0319 & 0.0134 & 0.0135\end{array}$

$\begin{array}{llllllllll}(1.34) & (0.48) & (0.28) & (0.41) & (0.02) & (0.04) & (1.43) & (0.87) & (0.49) & (0.51)\end{array}$

$\begin{array}{llllllllll}-0.0260 & -0.0244 & -0.0440 & -0.0443 & 0.0161 & 0.0109 & -0.0590 & -0.0456 & -0.0079 & -0.0079\end{array}$

$\begin{array}{llllllllll}(1.36) & (1.17) & (1.23) & (1.67) & (0.60) & (0.44) & (1.79)^{* * * *} & (1.24) & (0.37) & (0.38)\end{array}$

$\begin{array}{llllllllll}0.0618 & 0.0163 & -0.2151 & -0.2151 & 0.0122 & 0.0169 & -0.0782 & -0.0291 & 0.1196 & 0.1197\end{array}$

$\begin{array}{lllllll}(1.69)^{* * *}(0.42) & (1.96)^{* * *}(2.06)^{* * *}(0.31) & (0.44) & (1.45) & (0.49) & (1.89)^{* * *}(1.92)^{* * *}\end{array}$

$\begin{array}{llllllllll}0.0277 & 0.0095 & -0.0983 & -0.1000 & 0.0355 & 0.0403 & -0.1097 & -0.0293 & 0.1784 & 0.1785\end{array}$

$\begin{array}{lllllllll}(0.49) & (0.16) & (0.52) & (0.79) & (0.58) & (0.67) & (1.69)^{* * *}(0.43) & (2.12)^{* *} & (2.14)^{* *}\end{array}$

$\begin{array}{llllllllll}0.0839 & 0.0167 & -0.3323 & -0.3324 & -0.0202 & -0.0239 & -0.1011 & -0.0369 & 0.0659 & 0.0679\end{array}$

$\begin{array}{llllllllll}(2.23)^{* *} & (0.44) & (2.58)^{* *} & (2.74)^{* *} & (0.50) & (0.60) & (1.51) & (0.51) & (0.95) & (0.98)\end{array}$

$\begin{array}{llllllllll}-0.0548 & -0.0697 & -0.3769 & -0.3772 & 0.1020 & 0.1018 & -0.0705 & -0.0022 & 0.1752 & 0.1754\end{array}$

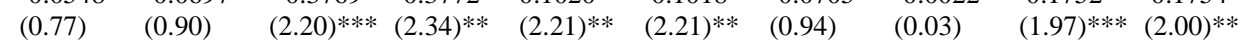

$\begin{array}{llllllllll}0.0445 & -0.0068 & -0.2636 & -0.2638 & 0.0088 & 0.0078 & -0.1054 & -0.0513 & 0.1265 & 0.1267\end{array}$

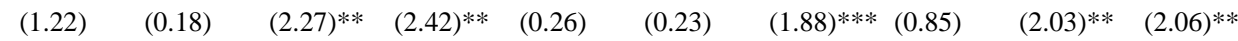

${ }^{4}$ All RHS variables are initial values from 1970.

5 All dollar values are in real 1992 dollars. 
Referee Appendix Table 2: Entire United States

\begin{tabular}{|c|c|c|c|c|c|c|c|c|c|c|}
\hline \multirow[b]{2}{*}{$\underline{\text { RHS Variables }}^{6}$} & \multicolumn{2}{|c|}{ ___Georgia } & \multicolumn{2}{|c|}{ ___Idaho___ } & \multicolumn{2}{|c|}{ Illinois } & \multicolumn{2}{|c|}{ Indiana___ } & \multicolumn{2}{|l|}{ Iowa } \\
\hline & $\underline{\text { OLS }}$ & $\underline{2 S L S}$ & $\underline{\text { OLS }}$ & $\underline{2 S L S}$ & $\underline{\text { OLS }}$ & $\underline{2 S L S}$ & $\underline{\text { OLS }}$ & $\underline{2 S L S}$ & $\underline{\text { OLS }}$ & $\underline{2 S L S}$ \\
\hline $\begin{array}{l}\text { Manufacturing - } \\
\text { nondurables }\end{array}$ & $\begin{array}{l}0.0315 \\
(0.88)\end{array}$ & $\begin{array}{l}-0.0102 \\
(0.27)\end{array}$ & $\begin{array}{l}-0.2664 \\
(2.30)^{* *}\end{array}$ & $\begin{array}{l}-0.2665 \\
(2.44)^{* *}\end{array}$ & $\begin{array}{l}0.0004 \\
(0.14)\end{array}$ & $\begin{array}{l}0.0036 \\
(0.11)\end{array}$ & $\begin{array}{l}-0.1024 \\
(1.85)^{* * *}\end{array}$ & $\begin{array}{l}-0.0513 \\
(0.85)\end{array}$ & $\begin{array}{l}0.1105 \\
(1.69)^{* * *}\end{array}$ & $\begin{array}{l}0.1107 \\
(1.70)^{* * *}\end{array}$ \\
\hline Mining & $\begin{array}{l}0.0510 \\
(1.38)\end{array}$ & $\begin{array}{l}0.0023 \\
(0.06)\end{array}$ & $\begin{array}{l}-0.2809 \\
(2.38)^{* *}\end{array}$ & $\begin{array}{l}-0.2812 \\
(2.57)^{* * *}\end{array}$ & $\begin{array}{l}-0.0068 \\
(0.19)\end{array}$ & $\begin{array}{l}-0.0058 \\
(0.16)\end{array}$ & $\begin{array}{l}-0.0907 \\
(1.36)\end{array}$ & $\begin{array}{l}-0.0356 \\
(0.49)\end{array}$ & $\begin{array}{l}0.1775 \\
(1.48)\end{array}$ & $\begin{array}{l}0.1778 \\
(1.50)\end{array}$ \\
\hline Retail & $\begin{array}{l}0.0325 \\
(0.86)\end{array}$ & $\begin{array}{l}-0.0210 \\
(0.53)\end{array}$ & $\begin{array}{l}-0.2952 \\
(2.54)^{* *}\end{array}$ & $\begin{array}{l}-0.2954 \\
(2.71)^{* *}\end{array}$ & $\begin{array}{l}-0.0042 \\
(0.12)\end{array}$ & $\begin{array}{l}-0.0072 \\
(0.20)\end{array}$ & $\begin{array}{l}-0.1465 \\
(2.27)^{* *}\end{array}$ & $\begin{array}{l}-0.0818 \\
(1.17)\end{array}$ & $\begin{array}{l}0.1393 \\
(2.10)^{* *}\end{array}$ & $\begin{array}{l}0.1395 \\
(2.15)^{* *}\end{array}$ \\
\hline $\begin{array}{l}\text { Business \& repair } \\
\text { services }\end{array}$ & $\begin{array}{l}0.2161 \\
(2.94)^{*}\end{array}$ & $\begin{array}{l}0.1994 \\
(2.49)^{* *}\end{array}$ & $\begin{array}{l}-0.2389 \\
(1.68)\end{array}$ & $\begin{array}{l}-0.2396 \\
(1.93)^{* * *}\end{array}$ & $\begin{array}{l}0.0724 \\
(1.04)\end{array}$ & $\begin{array}{l}0.0748 \\
(1.08)\end{array}$ & $\begin{array}{l}-0.2757 \\
(2.34)^{* *}\end{array}$ & $\begin{array}{l}-0.2109 \\
(1.62)\end{array}$ & $\begin{array}{l}0.0557 \\
(0.60)\end{array}$ & $\begin{array}{l}0.0554 \\
(0.60)\end{array}$ \\
\hline Educational services & $\begin{array}{l}0.0562 \\
(0.91)\end{array}$ & $\begin{array}{l}0.0588 \\
(0.87)\end{array}$ & $\begin{array}{l}-0.2809 \\
(1.35)\end{array}$ & $\begin{array}{l}-0.2826 \\
(1.88)^{* * *}\end{array}$ & $\begin{array}{l}-0.1155 \\
(1.69)^{* * *}\end{array}$ & $\begin{array}{l}-0.1139 \\
(1.70)^{* * *}\end{array}$ & $\begin{array}{l}-0.2513 \\
(2.66)^{*}\end{array}$ & $\begin{array}{l}-0.3292 \\
(3.18)^{*}\end{array}$ & $\begin{array}{l}-0.0233 \\
(0.48)\end{array}$ & $\begin{array}{l}-0.0233 \\
(0.48)\end{array}$ \\
\hline $\begin{array}{l}\text { Professional related } \\
\text { services }\end{array}$ & $\begin{array}{l}-0.0525 \\
(0.84)\end{array}$ & $\begin{array}{l}-0.0942 \\
(1.39)\end{array}$ & $\begin{array}{l}-0.0891 \\
(0.55)\end{array}$ & $\begin{array}{l}-0.0889 \\
(0.58)\end{array}$ & $\begin{array}{l}0.0644 \\
(0.81)\end{array}$ & $\begin{array}{l}0.0589 \\
(0.75)\end{array}$ & $\begin{array}{l}0.1320 \\
(1.24)\end{array}$ & $\begin{array}{l}0.2176 \\
(1.86)^{* * *}\end{array}$ & $\begin{array}{l}0.1294 \\
(1.72)^{* * *}\end{array}$ & $\begin{array}{l}0.1295 \\
(1.73)^{* * * *}\end{array}$ \\
\hline Health services & $\begin{array}{l}0.0587 \\
(0.96)\end{array}$ & $\begin{array}{l}0.0697 \\
(1.04)\end{array}$ & $\begin{array}{l}0.0856 \\
(0.48)\end{array}$ & $\begin{array}{l}0.0845 \\
(0.56)\end{array}$ & $\begin{array}{l}-0.1022 \\
(1.39)\end{array}$ & $\begin{array}{l}-0.0986 \\
(1.36)\end{array}$ & $\begin{array}{l}-0.2816 \\
(2.98)^{*}\end{array}$ & $\begin{array}{l}-0.3060 \\
(2.91)^{*}\end{array}$ & $\begin{array}{l}-0.0308 \\
(0.58)\end{array}$ & $\begin{array}{l}-0.0307 \\
(0.58)\end{array}$ \\
\hline Personal services & $\begin{array}{l}0.0652 \\
(1.44)\end{array}$ & $\begin{array}{l}0.0293 \\
(0.60)\end{array}$ & $\begin{array}{l}-0.1934 \\
(1.71)\end{array}$ & $\begin{array}{l}-0.1936 \\
(1.85)^{* * *}\end{array}$ & $\begin{array}{l}0.0641 \\
(0.86)\end{array}$ & $\begin{array}{l}0.0736 \\
(1.02)\end{array}$ & $\begin{array}{l}-0.0193 \\
(0.30)\end{array}$ & $\begin{array}{l}0.0278 \\
(0.39)\end{array}$ & $\begin{array}{l}0.1776 \\
(2.06)^{* *}\end{array}$ & $\begin{array}{l}0.1777 \\
(2.08)^{* *}\end{array}$ \\
\hline $\begin{array}{l}\text { Entertainment \& } \\
\text { recreational services }\end{array}$ & $\begin{array}{l}0.1824 \\
(1.48)\end{array}$ & $\begin{array}{l}0.2271 \\
(1.69)^{* * *}\end{array}$ & $\begin{array}{l}-0.2449 \\
(0.75)\end{array}$ & $\begin{array}{l}-0.2443 \\
(0.79)\end{array}$ & $\begin{array}{l}0.3805 \\
(2.29)^{* *}\end{array}$ & $\begin{array}{l}0.3781 \\
(2.29)^{* *}\end{array}$ & $\begin{array}{l}0.0797 \\
(0.41)\end{array}$ & $\begin{array}{l}0.1604 \\
(0.74)\end{array}$ & $\begin{array}{l}0.2593 \\
(1.45)\end{array}$ & $\begin{array}{l}0.2594 \\
(1.46)\end{array}$ \\
\hline Transportation & $\begin{array}{l}0.0222 \\
(0.53)\end{array}$ & $\begin{array}{l}-0.1591 \\
(0.35)\end{array}$ & $\begin{array}{l}-0.2889 \\
(2.30)^{* *}\end{array}$ & $\begin{array}{l}-0.2896 \\
(2.65)^{* *}\end{array}$ & $\begin{array}{l}-0.0339 \\
(0.84)\end{array}$ & $\begin{array}{l}-0.0352 \\
(0.88)\end{array}$ & $\begin{array}{l}-0.1411 \\
(2.17)^{* *}\end{array}$ & $\begin{array}{l}-0.0825 \\
(1.16)\end{array}$ & $\begin{array}{l}0.0548 \\
(0.81)\end{array}$ & $\begin{array}{l}0.0548 \\
(0.81)\end{array}$ \\
\hline Wholesale trade & $\begin{array}{l}0.0878 \\
(1.75)^{* * *}\end{array}$ & $\begin{array}{l}0.0376 \\
(0.70)\end{array}$ & $\begin{array}{l}-0.2639 \\
(1.82)\end{array}$ & $\begin{array}{l}-0.2638 \\
(1.92)^{* * *}\end{array}$ & $\begin{array}{l}0.0060 \\
(0.11)\end{array}$ & $\begin{array}{l}0.0074 \\
(0.14)\end{array}$ & $\begin{array}{l}0.0271 \\
(0.40)\end{array}$ & $\begin{array}{l}0.0658 \\
(0.89)\end{array}$ & $\begin{array}{l}0.1139 \\
(1.66)\end{array}$ & $\begin{array}{l}0.1141 \\
(1.69)^{* * * *}\end{array}$ \\
\hline Poverty & $\begin{array}{l}-0.0227 \\
(1.78)^{* * *}\end{array}$ & $\begin{array}{l}-0.0364 \\
(2.69)^{*}\end{array}$ & $\begin{array}{l}-0.0098 \\
(0.14)\end{array}$ & $\begin{array}{l}-0.0104 \\
(0.21)\end{array}$ & $\begin{array}{l}-0.0274 \\
(1.36)\end{array}$ & $\begin{array}{l}-0.0319 \\
(1.73)^{* * *}\end{array}$ & $\begin{array}{l}-0.0252 \\
(0.97)\end{array}$ & $\begin{array}{l}-0.0341 \\
(1.17)\end{array}$ & $\begin{array}{l}-0.0444 \\
(2.25)^{* *}\end{array}$ & $\begin{array}{l}-0.0446 \\
(2.64)^{* *}\end{array}$ \\
\hline Metro area, 1970 & $\begin{array}{l}0.0028 \\
(2.52)^{* *}\end{array}$ & $\begin{array}{c}0.0038 \\
(3.21)^{*}\end{array}$ & $\begin{array}{l}-0.0071 \\
(1.42)\end{array}$ & $\begin{array}{l}-0.0071 \\
(1.59)\end{array}$ & $\begin{array}{l}0.0013 \\
(1.55)\end{array}$ & $\begin{array}{l}0.0015 \\
(1.75)^{* * *}\end{array}$ & $\begin{array}{l}0.0004 \\
(0.48)\end{array}$ & $\begin{array}{l}0.0005 \\
(0.52)\end{array}$ & $\begin{array}{l}0.0009 \\
(0.79)\end{array}$ & $\begin{array}{l}0.0009 \\
(0.79)\end{array}$ \\
\hline $\begin{array}{l}\mathrm{R}^{2} \\
\text { Adjusted } \mathrm{R}^{2} \\
\text { \# Observations }\end{array}$ & $\begin{array}{l}0.50 \\
0.37 \\
160\end{array}$ & $\begin{array}{l}0.72 \\
0.65 \\
160\end{array}$ & $\begin{array}{l}0.94 \\
0.72 \\
44\end{array}$ & $\begin{array}{l}0.94 \\
0.77 \\
44\end{array}$ & $\begin{array}{l}0.72 \\
0.59 \\
102\end{array}$ & $\begin{array}{l}0.88 \\
0.82 \\
102 \\
\end{array}$ & $\begin{array}{l}0.73 \\
0.57 \\
92\end{array}$ & $\begin{array}{l}0.80 \\
0.69 \\
92\end{array}$ & $\begin{array}{l}0.65 \\
0.47 \\
99\end{array}$ & $\begin{array}{l}0.73 \\
0.60 \\
99\end{array}$ \\
\hline
\end{tabular}

${ }^{6}$ All RHS variables are initial values from 1970. 
RHS Variables $^{7}$

Constant

Log 1970 per capita income $^{8}$

Age: 5-13 years

Age: $14-17$ years

Age: 18-64 years

Age: $65+$

Blacks

Hispanic

Education: 9-11 years

Education: H.S. diploma

Education: Some college

Education: Bachelor +

Housing

Federal government employment

State government

employment

Local government employment

Self-employment

Agriculture

Communications

Construction

Finance, insurance $\&$ real estate

Manufacturing durables

\begin{tabular}{|c|c|c|c|c|c|c|c|c|c|}
\hline \multicolumn{2}{|c|}{ Kansas. } & \multicolumn{2}{|c|}{ Kentucky_ } & \multicolumn{2}{|c|}{ Louisiana } & \multicolumn{2}{|c|}{ Michigan } & \multicolumn{2}{|c|}{ Minnesota } \\
\hline LS & 2 SLS & DS & SLS & L S & $\underline{2 S L S}$ & $\underline{L S}$ & SLS & LS & SLS \\
\hline .39$)^{* *}$ & $\begin{array}{c}0.2332 \\
(2.66)^{* *}\end{array}$ & $\begin{array}{l}0.1237 \\
(1.26)\end{array}$ & $(2.3$ & $\begin{array}{l}0.2631 \\
(3.10)^{*}\end{array}$ & $(4.3$ & $\begin{array}{l}0.0441 \\
(0.31)\end{array}$ & $\begin{array}{l}0.3368 \\
(2.89)^{*}\end{array}$ & $\begin{array}{c}0.3382 \\
(2.59)^{* *}\end{array}$ & $\begin{array}{l}0.3998 \\
(3.09)^{*}\end{array}$ \\
\hline $\begin{array}{l}.0286 \\
.76)^{*}\end{array}$ & $\begin{array}{l}-0.03 \\
(12.1\end{array}$ & $\begin{array}{l}-0.02 \\
(6.11\end{array}$ & $\begin{array}{l}-0.02 \\
(19.7\end{array}$ & $\begin{array}{l}-0.0 \\
(3.8\end{array}$ & $(13$. & $(1.36)$ & $\begin{array}{l}-0.0 \\
(16 .\end{array}$ & $\begin{array}{l}-0 . \\
(2 .\end{array}$ & $(9.34)^{*}$ \\
\hline $\begin{array}{l}0.0541 \\
(0.70)\end{array}$ & $\begin{array}{l}0.0547 \\
(0.71)\end{array}$ & $\begin{array}{c}0.21 \\
(1.71\end{array}$ & $\begin{array}{c}0.2404 \\
(1.86)^{* * *}\end{array}$ & $\begin{array}{r}0.30 \\
(2.39\end{array}$ & $\begin{array}{c}0.3645 \\
(2.50)^{* *}\end{array}$ & 62 & $\begin{array}{l}-0.0501 \\
(0.30)\end{array}$ & & $\begin{array}{l}-0.1267 \\
(0.77)\end{array}$ \\
\hline $\begin{array}{l}0.0873 \\
(0.96)\end{array}$ & $\begin{array}{l}0.0887 \\
(0.98)\end{array}$ & $\begin{array}{l}0.0035 \\
(0.04)\end{array}$ & $\begin{array}{l}-0.0 \\
(0.0\end{array}$ & 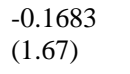 & $\begin{array}{l}-0.1097 \\
(0.97)\end{array}$ & 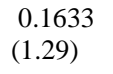 & $\begin{array}{l}0.1337 \\
(0.94)\end{array}$ & 40 & 3) \\
\hline $\begin{array}{l}0.0189 \\
(0.28)\end{array}$ & $\begin{array}{l}0.0186 \\
(0.27)\end{array}$ & $\begin{array}{r}0.08 \\
(0.97\end{array}$ & $\begin{array}{l}0.0919 \\
(1.06)\end{array}$ & $(0$ & $\begin{array}{l}0.0831 \\
(0.96)\end{array}$ & & $\begin{array}{l}.0101 \\
.09)\end{array}$ & & \\
\hline 000 & $\begin{array}{l}-0.0 \\
(0.0\end{array}$ & $\begin{array}{r}0.0 \\
(1.0\end{array}$ & 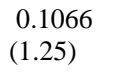 & & $(1$ & & ) & & \\
\hline $\begin{array}{l}.0528 \\
.28)^{* *}\end{array}$ & $\begin{array}{l}-0.05 \\
(2.29\end{array}$ & $\begin{array}{l}-0.00 \\
(0.43\end{array}$ & $(0.40)$ & & & & & & \\
\hline $\begin{array}{l}0.0082 \\
(0.32)\end{array}$ & $\begin{array}{l}0.0087 \\
(0.34)\end{array}$ & & & & & & & & \\
\hline 02 & $\begin{array}{l}-0.0 \\
(1.3\end{array}$ & $\begin{array}{r}0.0 \\
(0.4\end{array}$ & 0.0 & & $\begin{array}{l}0.0 \\
(0 .\end{array}$ & & 1) & & \\
\hline $\begin{array}{r}0.055 \\
(4.42)^{*}\end{array}$ & $\begin{array}{c}0 \\
(4\end{array}$ & 0 & 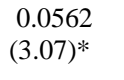 & & & & & & \\
\hline .0061 & $\begin{array}{l}-0.0 \\
(0.1\end{array}$ & 0.0 & $9 *$ & & $\begin{array}{c}0 \\
(1\end{array}$ & & 79 & & \\
\hline 0.0380 & $\begin{array}{r}0 \\
(1\end{array}$ & 0 & & & 7 & & $\begin{array}{l}3 \\
k *\end{array}$ & & \\
\hline 0.0000 & $\begin{array}{r}0 . \\
(1 .\end{array}$ & 0.0 & 0 & & 0 & & 100 & 0. & 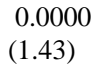 \\
\hline 0.0256 & $\begin{array}{l}0 \\
(0\end{array}$ & $(0$. & $\begin{array}{l}192 \\
5)^{* * *}\end{array}$ & & 2 & 7) & $\begin{array}{l}716 \\
5)\end{array}$ & & 61) \\
\hline 71) & $\begin{array}{r}0 \\
(0\end{array}$ & 0 & 41 & & & & 631 & $\begin{array}{l}0 . \\
(0\end{array}$ & 08 \\
\hline 0.0169 & $\begin{array}{c}0 \\
(1\end{array}$ & 0.0 & $(0$ & $* *$ & $(2$. & $0)$ & $\begin{array}{l}332 \\
7)\end{array}$ & 53 & $(1.03$ \\
\hline 5 & * & $\begin{array}{l}-0.0190 \\
(0.79)\end{array}$ & 19 & 7 & $\begin{array}{c}0 \\
(1\end{array}$ & 13 & 32 & & 37 \\
\hline 0.0461 & $\begin{array}{l}0.0468 \\
(0.81)\end{array}$ & $\begin{array}{l}0.0 \\
(0.8\end{array}$ & 219 & & 8 & $\begin{array}{l}617 \\
7)\end{array}$ & 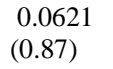 & $\begin{array}{l}-0 \\
(1\end{array}$ & $\begin{array}{l}-0.06 \\
(0.95\end{array}$ \\
\hline 0.0204 & $\begin{array}{l}0.0209 \\
(0.39)\end{array}$ & $\begin{array}{l}0 . \\
(0\end{array}$ & 6 & & $\begin{array}{r}0 . \\
(0 .\end{array}$ & 27 & 59 & 50 & $\begin{array}{l}-0.0767 \\
(0.99)\end{array}$ \\
\hline 304 & $\begin{array}{l}-0.0 \\
(0.6\end{array}$ & 0 & $\begin{array}{l}117 \\
4)\end{array}$ & $\begin{array}{l}5 \\
* * *\end{array}$ & $\begin{array}{l}-0 \\
(1\end{array}$ & 57 & 0.0565 & $\begin{array}{l}362 \\
5)\end{array}$ & $\begin{array}{l}0.0075 \\
(0.09)\end{array}$ \\
\hline $\begin{array}{l}0.0731 \\
(1.19)\end{array}$ & $\begin{array}{l}0.0736 \\
(1.21)\end{array}$ & $\begin{array}{l}-0.0642 \\
(1.01)\end{array}$ & $\begin{array}{l}-0.0762 \\
(1.17)\end{array}$ & $\begin{array}{l}-0.3863 \\
(3.32)^{*}\end{array}$ & $\begin{array}{l}-0.4473 \\
(3.39)^{*}\end{array}$ & $\begin{array}{l}0.0735 \\
(0.80)\end{array}$ & $\begin{array}{l}0.1029 \\
(1.01)\end{array}$ & $\begin{array}{l}-0.0721 \\
(0.76)\end{array}$ & $\begin{array}{l}0.0091 \\
(0.10)\end{array}$ \\
\hline $\begin{array}{c}0.02 \\
(0.46\end{array}$ & $\begin{array}{l}0.0226 \\
(0.45)\end{array}$ & $\begin{array}{l}0.0118 \\
(0.39)\end{array}$ & $\begin{array}{l}-0.0036 \\
(0.12)\end{array}$ & $\begin{array}{l}-0.1118 \\
(2.32)^{* *}\end{array}$ & $\begin{array}{l}-0.0982 \\
(1.78)^{* * *}\end{array}$ & $\begin{array}{l}0.0126 \\
(0.29)\end{array}$ & $\begin{array}{l}0.0239 \\
(0.49)\end{array}$ & $\begin{array}{l}-0.0880 \\
(1.32)\end{array}$ & $(0.75)$ \\
\hline
\end{tabular}

7 All RHS variables are initial values from 1970.

${ }_{8}$ All dollar values are in real 1992 dollars. 
Referee Appendix Table 3: Entire United States

$\underline{\text { RHS Variables }^{9}}$

Manufacturing nondurables

Mining

Retail

Business \& repair services

Educational services

Professional related services

Health services

Personal services

Entertainment \& recreational services

Transportation

Wholesale trade

Poverty

Metro area, 1970

$\mathrm{R}^{2}$

Adjusted $\mathrm{R}^{2}$

\# Observations

\begin{tabular}{|c|c|c|c|c|c|c|c|c|c|}
\hline \multicolumn{2}{|c|}{ Kansas } & \multicolumn{2}{|c|}{ Kentucky } & \multicolumn{2}{|c|}{ Louisiana } & \multicolumn{2}{|c|}{ __ Michigan } & \multicolumn{2}{|c|}{ __ Minnesota } \\
\hline$\underline{\text { OLS }}$ & $\underline{2 S L S}$ & $\underline{\text { OLS }}$ & $\underline{2 \mathrm{SLS}}$ & $\underline{\text { OLS }}$ & $\underline{2 \mathrm{SLS}}$ & $\underline{\text { OLS }}$ & $\underline{2 S L S}$ & $\underline{\text { OLS }}$ & $\underline{2 S L S}$ \\
\hline $\begin{array}{l}0.0165 \\
(0.29)\end{array}$ & $\begin{array}{l}0.0165 \\
(0.29)\end{array}$ & $\begin{array}{l}0.0115 \\
(0.37)\end{array}$ & $\begin{array}{l}-0.0082 \\
(0.26)\end{array}$ & $\begin{array}{l}-0.1029 \\
(2.11)^{* *}\end{array}$ & $\begin{array}{l}-0.0885 \\
(1.58)\end{array}$ & $\begin{array}{l}-0.0027 \\
(0.06)\end{array}$ & $\begin{array}{l}0.0015 \\
(0.03)\end{array}$ & $\begin{array}{l}-0.1100 \\
(1.59)\end{array}$ & $\begin{array}{l}-0.0640 \\
(0.96)\end{array}$ \\
\hline $\begin{array}{l}-0.0047 \\
(0.08)\end{array}$ & $\begin{array}{l}-0.0051 \\
(0.09)\end{array}$ & $\begin{array}{l}0.0086 \\
(0.29)\end{array}$ & $\begin{array}{l}0.0019 \\
(0.06)\end{array}$ & $\begin{array}{l}-0.1459 \\
(2.68)^{* *}\end{array}$ & $\begin{array}{l}-0.1385 \\
(2.22)^{* *}\end{array}$ & $\begin{array}{l}-0.0202 \\
(0.45)\end{array}$ & $\begin{array}{l}-0.0139 \\
(0.27)\end{array}$ & $\begin{array}{l}-0.1111 \\
(1.61)\end{array}$ & $\begin{array}{l}-0.0692 \\
(1.03)\end{array}$ \\
\hline $\begin{array}{l}0.0268 \\
(0.45)\end{array}$ & $\begin{array}{l}0.0263 \\
(0.44)\end{array}$ & $\begin{array}{l}-0.0017 \\
(0.04)\end{array}$ & $\begin{array}{l}-0.0087 \\
(0.22)\end{array}$ & $\begin{array}{l}-0.1666 \\
(3.00)^{*}\end{array}$ & $\begin{array}{l}-0.1539 \\
(2.42)^{* *}\end{array}$ & $\begin{array}{l}-0.0066 \\
(0.13)\end{array}$ & $\begin{array}{l}0.0101 \\
(0.18)\end{array}$ & $\begin{array}{l}-0.1072 \\
(1.38)\end{array}$ & $\begin{array}{l}-0.0613 \\
(0.81)\end{array}$ \\
\hline $\begin{array}{l}-0.0171 \\
(0.21)\end{array}$ & $\begin{array}{l}-0.0131 \\
(0.16)\end{array}$ & $\begin{array}{l}0.0143 \\
(0.19)\end{array}$ & $\begin{array}{l}0.0082 \\
(0.11)\end{array}$ & $\begin{array}{l}-0.1088 \\
(1.12)\end{array}$ & $\begin{array}{l}-0.1464 \\
(1.32)\end{array}$ & $\begin{array}{l}0.2241 \\
(1.63)\end{array}$ & $\begin{array}{r}0.3 \\
(2.4\end{array}$ & $\begin{array}{l}-0.1243 \\
(1.23)\end{array}$ & $\begin{array}{l}-0.0854 \\
(0.84)\end{array}$ \\
\hline $\begin{array}{l}-0.0162 \\
(0.42)\end{array}$ & $\begin{array}{l}-0.0162 \\
(0.43)\end{array}$ & $\begin{array}{l}0.0528 \\
(0.82)\end{array}$ & $\begin{array}{l}0.0254 \\
(0.39)\end{array}$ & $\begin{array}{l}0.0856 \\
(1.12)\end{array}$ & $\begin{array}{l}0.0083 \\
(0.10)\end{array}$ & 07 & 43 & $\begin{array}{l}-0 \\
(0\end{array}$ & $\begin{array}{l}-0.0878 \\
(1.40)\end{array}$ \\
\hline $\begin{array}{l}0.0232 \\
(0.33)\end{array}$ & $\begin{array}{l}0.0218 \\
(0.32)\end{array}$ & $\begin{array}{l}-0.0444 \\
(0.75)\end{array}$ & $\begin{array}{l}-0.0443 \\
(0.73)\end{array}$ & $\begin{array}{l}-0.1746 \\
(2.11)^{* *}\end{array}$ & $\begin{array}{l}-0.0861 \\
(0.96)\end{array}$ & $\begin{array}{l}0.0544 \\
(0.59)\end{array}$ & $\begin{array}{l}0.0353 \\
(0.34)\end{array}$ & $\begin{array}{l}-0.0873 \\
(0.91)\end{array}$ & $\begin{array}{l}0.0034 \\
(0.04)\end{array}$ \\
\hline $\begin{array}{l}-0.0093 \\
(0.24)\end{array}$ & $\begin{array}{l}-0.0062 \\
(0.16)\end{array}$ & $\begin{array}{l}0.0931 \\
(1.43)\end{array}$ & $\begin{array}{l}0.0724 \\
(1.09)\end{array}$ & $\begin{array}{l}0.0766 \\
(0.94)\end{array}$ & $\begin{array}{l}-0.0051 \\
(0.06)\end{array}$ & $\begin{array}{l}-0.0245 \\
(0.26)\end{array}$ & $\begin{array}{l}0.0150 \\
(0.14)\end{array}$ & & $\begin{array}{l}-0.0731 \\
(1.22)\end{array}$ \\
\hline $\begin{array}{l}-0.0797 \\
(1.14)\end{array}$ & $\begin{array}{l}-0.0778 \\
(1.12)\end{array}$ & $\begin{array}{l}0.0741 \\
(1.43)\end{array}$ & $\begin{array}{l}0.0575 \\
(1.09)\end{array}$ & $\begin{array}{l}-0.0306 \\
(0.46)\end{array}$ & $\begin{array}{l}-0.0464 \\
(0.61)\end{array}$ & $\begin{array}{l}0.0471 \\
(0.72)\end{array}$ & $\begin{array}{l}0.0406 \\
(0.55)\end{array}$ & $\begin{array}{l}-0 . \\
(1 .\end{array}$ & $\begin{array}{l}-0.0411 \\
(0.50)\end{array}$ \\
\hline $\begin{array}{l}0.0745 \\
(0.68)\end{array}$ & $\begin{array}{l}0.0679 \\
(0.63)\end{array}$ & $\begin{array}{l}0.1546 \\
(1.06)\end{array}$ & $\begin{array}{l}0.1347 \\
(0.90)\end{array}$ & $\begin{array}{l}0.1707 \\
(0.81)\end{array}$ & $\begin{array}{c}0.4228 \\
(1.86)^{* * *}\end{array}$ & $\begin{array}{l}-0.2251 \\
(1.22)\end{array}$ & $\begin{array}{l}-0.2559 \\
(1.24)\end{array}$ & $\begin{array}{l}-0.0978 \\
(0.54)\end{array}$ & $\begin{array}{l}-0.0524 \\
(0.29)\end{array}$ \\
\hline $\begin{array}{l}0.0188 \\
(0.30)\end{array}$ & $\begin{array}{l}0.0193 \\
(0.31)\end{array}$ & $\begin{array}{l}0.0054 \\
(0.15)\end{array}$ & $\begin{array}{l}-0.0161 \\
(0.45)\end{array}$ & $\begin{array}{l}-0.1215 \\
(1.83)^{* * *}\end{array}$ & $\begin{array}{l}-0.0675 \\
(0.91\end{array}$ & $\begin{array}{l}-0.0009 \\
(0.02)\end{array}$ & $\begin{array}{c}0.0047 \\
(0.07)\end{array}$ & $\begin{array}{l}-0.1254 \\
(1.40)\end{array}$ & $\begin{array}{l}-0.0836 \\
(0.94)\end{array}$ \\
\hline $\begin{array}{l}0.0827 \\
(1.26)\end{array}$ & $\begin{array}{l}0.0821 \\
(1.26)\end{array}$ & $\begin{array}{l}0.0060 \\
(0.11)\end{array}$ & $\begin{array}{l}-0.0038 \\
(0.07)\end{array}$ & $\begin{array}{l}0.0400 \\
(0.60)\end{array}$ & $\begin{array}{l}0.0504 \\
(0.65)\end{array}$ & $\begin{array}{l}0.0398 \\
(0.70)\end{array}$ & $\begin{array}{l}0.0382 \\
(0.60)\end{array}$ & $\begin{array}{l}-0.1204 \\
(1.64)\end{array}$ & $\begin{array}{l}-0.0703 \\
(1.00)\end{array}$ \\
\hline $\begin{array}{l}0.0072 \\
(0.57)\end{array}$ & $\begin{array}{l}0.0127 \\
(0.54)\end{array}$ & $\begin{array}{l}-0.0111 \\
(0.95)\end{array}$ & $\begin{array}{l}-0.0234 \\
(2.14)^{* *}\end{array}$ & $\begin{array}{l}-0.0355 \\
(2.02)^{* * *}\end{array}$ & $\begin{array}{l}-0.0661 \\
(3.84)^{*}\end{array}$ & $\begin{array}{l}-0.0594 \\
(1.58)\end{array}$ & $\begin{array}{l}-0.0931 \\
(2.27)^{* *}\end{array}$ & $\begin{array}{l}-0.0106 \\
(0.39)\end{array}$ & $\begin{array}{l}-0.0457 \\
(2.20)^{* *}\end{array}$ \\
\hline $\begin{array}{l}0.0013 \\
(1.00)\end{array}$ & $\begin{array}{l}0.0013 \\
(0.98)\end{array}$ & $\begin{array}{c}0.0055 \\
(3.28)^{*}\end{array}$ & $\begin{array}{c}0.0057 \\
(3.29)^{*}\end{array}$ & $\begin{array}{l}0.0003 \\
(0.34)\end{array}$ & $\begin{array}{l}0.0008 \\
(0.76)\end{array}$ & $\begin{array}{l}0.0008 \\
(0.48)\end{array}$ & $\begin{array}{l}0.0011 \\
(0.57)\end{array}$ & $\begin{array}{l}-0.0001 \\
(0.10)\end{array}$ & $\begin{array}{l}-0.0003 \\
(0.27)\end{array}$ \\
\hline & & & & & & & & & \\
\hline & & & & & & & & & 0.68 \\
\hline 106 & 106 & 120 & 120 & 64 & 64 & 83 & 83 & 87 & 87 \\
\hline
\end{tabular}

* significant at $1 \%$ level

** significant at $5 \%$ level

*** significant at $10 \%$ level

\footnotetext{
9 All RHS variables are initial values from 1970.
} 
RHS Variables $^{10}$

Constant

Log 1970 per capita income $^{11}$

Age: 5-13 years

Age: $14-17$ years

Age: 18-64 years

Age: $65+$

Blacks

Hispanic

Education: 9-11 years

Education: Some college

Education: Bachelor +

Housing

Federal government employment

State government

Employment

Local government employment

Self-employment

Agriculture

Communications

Construction

Finance, insurance $\&$ real estate

Manufacturing durables
Education: H.S. diploma

_ Mississippi

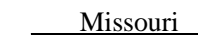

\section{O}

$\begin{array}{cccc}0.3108 & 0.5456 & 0.1385 & 0.4189 \\ (1.82)^{* * *} & (3.33)^{*} & (1.60) & (4.66)^{*}\end{array}$

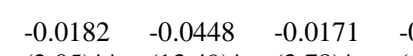

$$
(2.05
$$

$-0.1034-0.0081$ $(0.62)$

$\begin{array}{llllllllll}-0.1236 & -0.1694 & 0.0695 & 0.1422 & 0.0185 & -0.0352 & -0.0669 & 0.0732 & -0.2237 & -0.2487\end{array}$

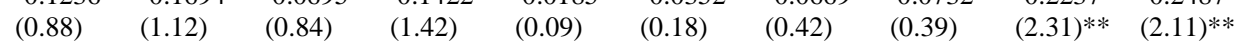

$\begin{array}{llllllllll}-0.1050 & -0.0491 & 0.0859 & 0.1029 & 0.1622 & 0.1079 & -0.0683 & 0.1155 & -0.0249 & 0.0062\end{array}$

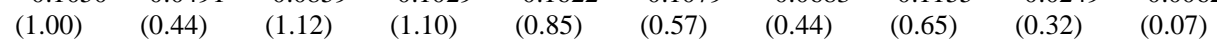

$\begin{array}{llllllllll}-0.1743 & -0.1724 & 0.0287 & 0.0133 & 0.1538 & 0.0914 & -0.0793 & 0.1127 & 0.0087 & 0.0106 \\ (1.60) & (1.47) & (0.40) & (0.15) & (1.10) & (0.67) & (0.39) & (0.47) & (0.13) & (0.13)\end{array}$

$\begin{array}{llllllllll}(1.60) & (1.47) & (0.40) & (0.15) & (1.10) & (0.67) & (0.39) & (0.47) & (0.13) & (0.13)\end{array}$

$\begin{array}{llllllllll}-0.0114 & -0.0154 & 0.0057 & 0.0255 & -0.1714 & -0.2622 & -0.0402 & -0.0119 & 0.0041 & 0.0135\end{array}$

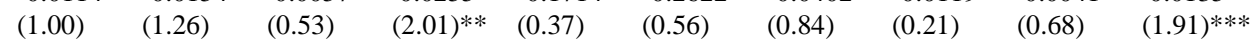

$\begin{array}{llllllllll}-0.2929 & -0.4960 & -0.0826 & -0.2560 & -0.0150 & 0.0068 & -0.0480 & -0.0576 & -0.0046 & 0.0725\end{array}$

$\begin{array}{lllllllll}(1.07) & (1.73)^{* * *}(0.67) & (1.74)^{* * *}(0.11) & (0.05) & (1.11) & (1.10) & (0.03) & (0.38)\end{array}$

$\begin{array}{llllllllll}-0.000 & 0.0095 & -0.0121 & -0.0226 & -0.1061 & -0.1081 & 0.0273 & 0.0306 & 0.0220 & 0.0395\end{array}$

$\begin{array}{llllllllll}-0.000 & 0.0095 & -0.0121 & -0.0226 & -0.1061 & -0.1081 & 0.0273 & 0.0306 & 0.0220 & 0.0395 \\ (0.30) & (0.54) & (0.83) & (1.55) & (1.54) & (0.74) & (0.68) & (1.24) & (1.85)^{* * *}\end{array}$

$\begin{array}{llllllllll}-0.0779 & -0.0950 & -0.0143 & 0.0187 & -0.0241 & -0.0028 & -0.0368 & -0.0719 & 0.0077 & 0.0223\end{array}$

$\begin{array}{lllllllll}(1.96)^{* * *} & (2.24)^{* *} & (0.96) & (1.11) & (0.58) & (0.07) & (0.91) & (1.51) & (0.45)\end{array}$

$\begin{array}{llllllllll}0.0255 & -0.0352 & -0.0082 & -0.0271 & -0.0011 & 0.0100 & 0.0129 & 0.0193 & 0.0213 & -0.0162\end{array}$

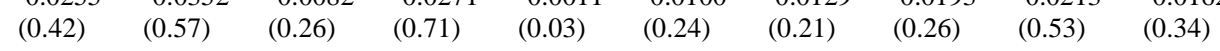

$\begin{array}{llllllllll}-0.0678 & 0.0182 & 0.0635 & 0.1255 & -0.0061 & 0.0085 & 0.0735 & 0.1734 & 0.0449 & 0.1134\end{array}$

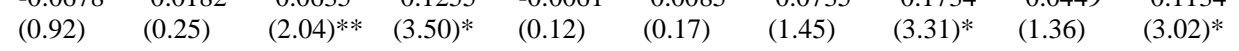

$\begin{array}{llllllllll}-0.0000 & -0.0000 & 0.0000 & 0.0000 & 0.0000 & 0.0000 & -0.0000 & -0.0000 & -0.0000 & 0.0000\end{array}$

$\begin{array}{lllllllll}(1.47) & (1.06) & (0.10) & (1.01) & (0.73) & (0.40) & (0.24) & (0.36) & (0.85)\end{array}$

$\begin{array}{llllllllll}0.0427 & 0.0127 & -0.0559 & -0.0917 & -0.0603 & -0.0854 & 0.0442 & 0.0966 & -0.0978 & -0.1674\end{array}$

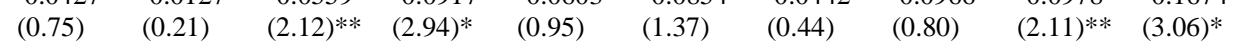

$\begin{array}{llllllllll}0.0181 & -0.0396 & -0.0264 & -0.0655 & 0.0254 & -0.0057 & 0.0245 & 0.0531 & -0.0154 & -0.0432\end{array}$

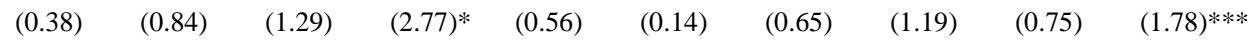

$\begin{array}{llllllllll}-0.0718 & -0.1485 & -0.0236 & -0.0205 & -0.0107 & -0.0132 & 0.0022 & 0.0072 & 0.0148 & -0.0038\end{array}$

$\begin{array}{llllllllll}(1.19) & (2.51)^{* *} & (0.99) & (0.70) & (0.26) & (0.32) & (0.04) & (0.11) & (0.34) & (0.07)\end{array}$

$\begin{array}{llllllllll}0.0848 & 0.0851 & -0.0031 & -0.0218 & 0.0163 & 0.0132 & 0.0105 & 0.0009 & -0.0103 & -0.0172\end{array}$

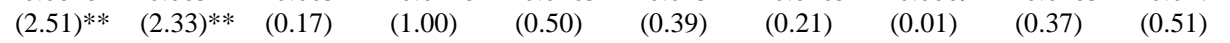

$\begin{array}{llllllllll}-0.0431 & -0.0716 & -0.0292 & -0.0447 & 0.0023 & -0.0027 & -0.0075 & 0.0571 & -0.1168 & -0.1372\end{array}$

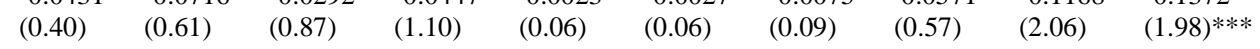

$\begin{array}{llllllllll}-0.1040 & -0.1188 & -0.1179 & -0.1158 & 0.1099 & 0.0782 & 0.0168 & 0.0992 & -0.0812 & -0.1256\end{array}$

$\begin{array}{lllllllll}(0.72) & (0.77) & (2.05)^{* *} & (1.65)^{* * *} & (1.41) & (1.02) & (0.14) & (0.67) & (1.27)\end{array}$

$\begin{array}{llllllllll}-0.0063 & -0.0109 & -0.0074 & -0.0254 & 0.0727 & 0.0611 & 0.0808 & 0.1264 & -0.1420 & -0.1908 \\ (0.06) & (0.10) & (0.20) & (0.57) & (1.46) & (1.22) & (1.03) & (1.34) & (2.68)^{*} & (2.99)^{*} \\ & & & & & & & & & \\ 0.1737 & 0.1244 & 0.0005 & -0.0001 & 0.1315 & 0.1345 & 0.0038 & 0.0759 & -0.0386 & -0.0858 \\ (1.05) & (0.70) & (0.01) & (0.01) & (1.13) & (1.13) & (0.05) & (0.77) & (0.43) & (0.79) \\ & & & & & & & & & \\ -0.0081 & -0.0392 & -0.0370 & -0.0827 & 0.0328 & 0.0178 & 0.0164 & 0.0631 & -0.1194 & -0.1752 \\ (0.08) & (0.35) & (1.20) & (2.27)^{* *} & (0.77) & (0.42) & (0.27) & (0.87) & (2.31)^{* *} & (2.84)^{*}\end{array}$

${ }_{10}$ All RHS variables are initial values from 1970

11 All dollar values are in real 1992 dollars. 
Referee Appendix Table 4: Entire United States

\begin{tabular}{|c|c|c|c|c|c|c|c|c|c|c|}
\hline \multirow[b]{2}{*}{$\underline{\text { RHS Variables }}^{12}$} & \multicolumn{2}{|c|}{ Mississippi } & \multicolumn{2}{|c|}{ Missouri } & \multicolumn{2}{|c|}{ Montana__- } & \multicolumn{2}{|c|}{ New York } & \multicolumn{2}{|c|}{ _North Carolina } \\
\hline & $\underline{\text { OLS }}$ & $\underline{2 S L S}$ & $\underline{\text { OLS }}$ & $\underline{2 S L S}$ & $\underline{\text { OLS }}$ & $\underline{2 S L S}$ & $\underline{\text { OLS }}$ & $\underline{2 S L S}$ & $\underline{\text { OLS }}$ & $\underline{2 S L S}$ \\
\hline $\begin{array}{l}\text { Manufacturing - } \\
\text { nondurables }\end{array}$ & $\begin{array}{l}-0.0246 \\
(0.23)\end{array}$ & $\begin{array}{l}-0.0661 \\
(0.59)\end{array}$ & $\begin{array}{l}-0.0391 \\
(1.26)\end{array}$ & $\begin{array}{l}-0.0699 \\
(1.88)^{* * *}\end{array}$ & $\begin{array}{l}-0.0120 \\
(0.17)\end{array}$ & $\begin{array}{l}-0.0155 \\
(0.21)\end{array}$ & $\begin{array}{l}0.0316 \\
(0.49)\end{array}$ & $\begin{array}{l}0.0778 \\
(1.01)\end{array}$ & $\begin{array}{l}-0.1416 \\
(2.72)^{*}\end{array}$ & $\begin{array}{l}-0.1998 \\
(3.21)^{*}\end{array}$ \\
\hline Mining & $\begin{array}{l}0.0009 \\
(0.01)\end{array}$ & $\begin{array}{l}-0.0598 \\
(0.53)\end{array}$ & $\begin{array}{l}-0.0572 \\
(1.79)^{* * *}\end{array}$ & $\begin{array}{l}-0.0705 \\
(1.82)^{* * *}\end{array}$ & $\begin{array}{l}0.0254 \\
(0.49)\end{array}$ & $\begin{array}{l}0.0095 \\
(0.18)\end{array}$ & $\begin{array}{l}-0.0942 \\
(0.99)\end{array}$ & $\begin{array}{l}-0.0588 \\
(0.51)\end{array}$ & $\begin{array}{l}-0.1547 \\
(2.01)^{* *}\end{array}$ & $\begin{array}{l}-0.2081 \\
(2.23)^{* *}\end{array}$ \\
\hline Retail & $\begin{array}{l}0.0001 \\
(0.01)\end{array}$ & $\begin{array}{l}-0.0274 \\
(0.23)\end{array}$ & $\begin{array}{l}-0.0384 \\
(1.11)\end{array}$ & $\begin{array}{l}-0.0801 \\
(1.94)^{* * *}\end{array}$ & $\begin{array}{l}0.0381 \\
(0.78)\end{array}$ & $\begin{array}{l}0.0224 \\
(0.46)\end{array}$ & $\begin{array}{l}0.0182 \\
(0.26)\end{array}$ & $\begin{array}{l}0.0633 \\
(0.75)\end{array}$ & $\begin{array}{l}-0.1801 \\
(3.24)^{*}\end{array}$ & $\begin{array}{l}-0.2204 \\
(3.27)^{*}\end{array}$ \\
\hline $\begin{array}{l}\text { Business \& repair } \\
\text { services }\end{array}$ & $\begin{array}{l}-0.1410 \\
(0.74)\end{array}$ & $\begin{array}{l}-0.2227 \\
(1.10)\end{array}$ & $\begin{array}{l}-0.0277 \\
(0.38)\end{array}$ & $\begin{array}{l}-0.0951 \\
(1.10)\end{array}$ & $\begin{array}{l}-0.1562 \\
(1.47)\end{array}$ & $\begin{array}{l}-0.1282 \\
(1.20)\end{array}$ & $\begin{array}{l}0.1056 \\
(0.63)\end{array}$ & $\begin{array}{l}0.2947 \\
(1.52)\end{array}$ & $\begin{array}{l}-0.1992 \\
(1.79)^{* * *}\end{array}$ & $\begin{array}{l}-0.3455 \\
(2.61)^{* *}\end{array}$ \\
\hline Educational services & $\begin{array}{l}-0.2489 \\
(2.12)^{* *}\end{array}$ & $\begin{array}{l}-0.2426 \\
(1.92)^{* * *}\end{array}$ & $\begin{array}{l}-0.0148 \\
(0.29)\end{array}$ & $\begin{array}{l}0.0243 \\
(0.39)\end{array}$ & $\begin{array}{l}-0.0632 \\
(0.89)\end{array}$ & $\begin{array}{l}-0.0476 \\
(0.66)\end{array}$ & $\begin{array}{l}-0.0468 \\
(0.35)\end{array}$ & $\begin{array}{l}-0.0830 \\
(0.51)\end{array}$ & $\begin{array}{l}0.0900 \\
(1.00)\end{array}$ & $\begin{array}{l}0.0923 \\
(0.84)\end{array}$ \\
\hline $\begin{array}{l}\text { Professional related } \\
\text { services }\end{array}$ & $\begin{array}{l}0.2260 \\
(1.49)\end{array}$ & $\begin{array}{l}0.1967 \\
(1.20)\end{array}$ & $\begin{array}{l}-0.0340 \\
(0.58)\end{array}$ & $\begin{array}{l}-0.1245 \\
(1.79)^{* * *}\end{array}$ & $\begin{array}{l}0.0621 \\
(0.86)\end{array}$ & $\begin{array}{l}0.0533 \\
(0.72)\end{array}$ & $\begin{array}{l}0.0558 \\
(0.39)\end{array}$ & $\begin{array}{l}0.0421 \\
(0.24)\end{array}$ & $\begin{array}{l}-0.2484 \\
(2.53)^{* *}\end{array}$ & $\begin{array}{l}-0.3286 \\
(2.77)^{*}\end{array}$ \\
\hline Health services & $\begin{array}{l}-0.2955 \\
(2.31)^{* *}\end{array}$ & $\begin{array}{l}-0.2399 \\
(1.75)^{* * *}\end{array}$ & $\begin{array}{l}0.0047 \\
(0.10)\end{array}$ & $\begin{array}{l}0.0624 \\
(1.07)\end{array}$ & $\begin{array}{l}-0.0134 \\
(0.17)\end{array}$ & $\begin{array}{l}0.0223 \\
(0.30)\end{array}$ & $\begin{array}{l}-0.0077 \\
(0.05)\end{array}$ & $\begin{array}{l}0.0122 \\
(0.07)\end{array}$ & $\begin{array}{l}0.1273 \\
(1.71)^{* * *}\end{array}$ & $\begin{array}{l}0.1582 \\
(1.75)^{* * *}\end{array}$ \\
\hline Personal services & $\begin{array}{l}0.0370 \\
(0.35)\end{array}$ & $\begin{array}{l}0.0567 \\
(0.50)\end{array}$ & $\begin{array}{l}-0.0031 \\
(0.08)\end{array}$ & $\begin{array}{l}0.0068 \\
(0.14)\end{array}$ & $\begin{array}{l}0.0282 \\
(0.32)\end{array}$ & $\begin{array}{l}0.0218 \\
(0.24)\end{array}$ & $\begin{array}{l}0.0028 \\
(0.03)\end{array}$ & $\begin{array}{l}0.0089 \\
(0.09)\end{array}$ & $\begin{array}{l}-0.1249 \\
(1.83)^{* * *}\end{array}$ & $\begin{array}{l}-0.1732 \\
(2.10)^{* *}\end{array}$ \\
\hline $\begin{array}{l}\text { Entertainment \& } \\
\text { recreational services }\end{array}$ & $\begin{array}{c}1.0238 \\
(3.05)^{*}\end{array}$ & $\begin{array}{r}1.1467 \\
(3.18)^{*}\end{array}$ & $\begin{array}{l}-0.0605 \\
(0.40)\end{array}$ & $\begin{array}{l}-0.1223 \\
(0.67)\end{array}$ & $\begin{array}{l}0.2369 \\
(1.36)\end{array}$ & $\begin{array}{l}0.2268 \\
(1.27)\end{array}$ & $\begin{array}{l}0.3201 \\
(1.12)\end{array}$ & $\begin{array}{c}0.7624 \\
(2.40)^{* *}\end{array}$ & $\begin{array}{l}0.1819 \\
(1.22)\end{array}$ & $\begin{array}{l}0.1474 \\
(0.81)\end{array}$ \\
\hline Transportation & $\begin{array}{l}-0.0308 \\
(0.30)\end{array}$ & $\begin{array}{l}-0.0415 \\
(0.37)\end{array}$ & $\begin{array}{l}-0.0292 \\
(0.77)\end{array}$ & $\begin{array}{l}-0.0770 \\
(1.70)^{* * *}\end{array}$ & $\begin{array}{l}0.0065 \\
(0.11)\end{array}$ & $\begin{array}{l}-0.0142 \\
(0.24)\end{array}$ & $\begin{array}{l}0.0900 \\
(0.97)\end{array}$ & $\begin{array}{l}0.1087 \\
(0.97)\end{array}$ & $\begin{array}{l}-0.1160 \\
(1.95) * * *\end{array}$ & $\begin{array}{l}-0.1559 \\
(2.15)^{* *}\end{array}$ \\
\hline Wholesale trade & $\begin{array}{l}0.1385 \\
(1.16)\end{array}$ & $\begin{array}{l}0.1419 \\
(1.10)\end{array}$ & $\begin{array}{l}0.0228 \\
(0.43)\end{array}$ & $\begin{array}{l}-0.0855 \\
(1.38)\end{array}$ & $\begin{array}{l}0.0107 \\
(0.10)\end{array}$ & $\begin{array}{l}0.0090 \\
(0.08)\end{array}$ & $\begin{array}{l}-0.0617 \\
(0.55)\end{array}$ & $\begin{array}{l}-0.0007 \\
(0.01)\end{array}$ & $\begin{array}{l}-0.0583 \\
(0.85)\end{array}$ & $\begin{array}{l}-0.1009 \\
(1.21)\end{array}$ \\
\hline Poverty & $\begin{array}{l}-0.0210 \\
(0.98)\end{array}$ & $\begin{array}{l}-0.0452 \\
(2.10)^{* *}\end{array}$ & $\begin{array}{l}-0.0271 \\
(2.05)^{* *}\end{array}$ & $\begin{array}{l}-0.0853 \\
(7.51)^{*}\end{array}$ & $\begin{array}{l}0.0302 \\
(1.16)\end{array}$ & $\begin{array}{l}0.0132 \\
(0.56)\end{array}$ & $\begin{array}{l}0.0941 \\
(1.57)\end{array}$ & $\begin{array}{l}-0.0132 \\
(0.21)\end{array}$ & $\begin{array}{l}0.0052 \\
(0.28)\end{array}$ & $\begin{array}{l}-0.0468 \\
(2.32)^{* *}\end{array}$ \\
\hline Metro area, 1970 & $\begin{array}{c}0.0068 \\
(3.77)^{*}\end{array}$ & $\begin{array}{l}0.0076 \\
(3.93)^{*}\end{array}$ & $\begin{array}{l}0.0011 \\
(1.09)\end{array}$ & $\begin{array}{c}0.0026 \\
(2.09)^{* *}\end{array}$ & $\begin{array}{l}0.0000 \\
(0.00)\end{array}$ & $\begin{array}{l}0.0000 \\
(0.00)\end{array}$ & $\begin{array}{l}0.0011 \\
(0.54)\end{array}$ & $\begin{array}{l}0.0014 \\
(0.57)\end{array}$ & $\begin{array}{c}0.0021 \\
(2.06)^{* *}\end{array}$ & $\begin{array}{l}0.0017 \\
(1.39)\end{array}$ \\
\hline $\begin{array}{l}\mathrm{R}^{2} \\
\text { Adjusted } \mathrm{R}^{2} \\
\text { \# Observations }\end{array}$ & $\begin{array}{l}0.51 \\
0.54 \\
82\end{array}$ & $\begin{array}{l}0.87 \\
0.78 \\
82 \\
\end{array}$ & $\begin{array}{l}0.59 \\
0.41 \\
115 \\
\end{array}$ & $\begin{array}{l}0.90 \\
0.86 \\
115 \\
\end{array}$ & $\begin{array}{l}0.86 \\
0.65 \\
56 \\
\end{array}$ & $\begin{array}{l}0.78 \\
0.48 \\
56\end{array}$ & $\begin{array}{l}0.80 \\
0.55 \\
62 \\
\end{array}$ & $\begin{array}{l}0.90 \\
0.80 \\
62 \\
\end{array}$ & $\begin{array}{l}0.65 \\
0.47 \\
100 \\
\end{array}$ & $\begin{array}{l}0.89 \\
0.83 \\
100 \\
\end{array}$ \\
\hline
\end{tabular}

${ }^{12}$ All RHS variables are initial values from 1970. Also, state dummies were employed in all regressions. 


\begin{tabular}{|c|c|c|c|c|c|c|c|c|c|c|}
\hline \multirow[b]{2}{*}{$\underline{\text { RHS Variables }}{ }^{13}$} & \multicolumn{2}{|c|}{ _North Dakota } & \multicolumn{2}{|l|}{ Ohio } & \multicolumn{2}{|c|}{ _ Oklahoma } & \multicolumn{2}{|c|}{ _Pennsylvania_ } & \multicolumn{2}{|c|}{ _South Carolina } \\
\hline & $\underline{\text { OLS }}$ & $\underline{2 S L S}$ & $\underline{\text { OLS }}$ & $\underline{2 S L S}$ & $\underline{\text { OLS }}$ & $\underline{2 S L S}$ & $\underline{\text { OLS }}$ & $\underline{2 S L S}$ & $\underline{\text { OLS }}$ & $\underline{2 S L S}$ \\
\hline Constant & $\begin{array}{l}-0.4522 \\
(1.96)^{* * *}\end{array}$ & $\begin{array}{l}-0.4216 \\
(1.43)\end{array}$ & $\begin{array}{l}-0.0094 \\
(0.07)\end{array}$ & $\begin{array}{l}0.1022 \\
(0.86)\end{array}$ & $\begin{array}{l}0.2289 \\
(1.44)\end{array}$ & $\begin{array}{l}0.3319 \\
(2.10)^{* *}\end{array}$ & $\begin{array}{l}-0.0613 \\
(0.37)\end{array}$ & $\begin{array}{l}0.1197 \\
(0.84)\end{array}$ & $\begin{array}{l}0.2060 \\
(0.51)\end{array}$ & $\begin{array}{l}0.4611 \\
(1.35)\end{array}$ \\
\hline $\begin{array}{l}\text { Log } 1970 \text { per capita } \\
\text { income }^{14}\end{array}$ & $\begin{array}{l}-0.0279 \\
(3.29)^{*}\end{array}$ & $\begin{array}{l}-0.0594 \\
(4.79)^{*}\end{array}$ & $\begin{array}{l}-0.0136 \\
(1.87)^{* * *}\end{array}$ & $\begin{array}{l}-0.0274 \\
(7.68)^{*}\end{array}$ & $\begin{array}{l}-0.0248 \\
(3.95)^{*}\end{array}$ & $\begin{array}{l}-0.0387 \\
(22.11)^{*}\end{array}$ & $\begin{array}{l}-0.0176 \\
(2.53)^{* *}\end{array}$ & $\begin{array}{l}-0.0312 \\
(9.01)^{*}\end{array}$ & $\begin{array}{l}-0.0118 \\
(0.62)\end{array}$ & $\begin{array}{l}-0.0336 \\
(5.97)^{*}\end{array}$ \\
\hline Age: $5-13$ years & $\begin{array}{l}0.5189 \\
(1.94)^{* * *}\end{array}$ & $\begin{array}{l}0.6363 \\
(1.87)^{* * *}\end{array}$ & $\begin{array}{l}0.3202 \\
(2.03)^{* *}\end{array}$ & $\begin{array}{l}0.3234 \\
(2.01)^{* *}\end{array}$ & $\begin{array}{l}0.1995 \\
(1.02)\end{array}$ & $\begin{array}{l}0.2122 \\
(1.04)\end{array}$ & $\begin{array}{l}0.4895 \\
(2.61)^{* *}\end{array}$ & $\begin{array}{l}0.4189 \\
(2.18)^{* *}\end{array}$ & $\begin{array}{l}0.0643 \\
(0.19)\end{array}$ & $\begin{array}{l}0.0653 \\
(0.19)\end{array}$ \\
\hline Age: $14-17$ years & $\begin{array}{l}0.4353 \\
(2.28)^{* *}\end{array}$ & $\begin{array}{l}0.6903 \\
(3.03)^{*}\end{array}$ & $\begin{array}{l}0.2181 \\
(2.08) * *\end{array}$ & $\begin{array}{l}0.1811 \\
(1.72)^{* * *}\end{array}$ & $\begin{array}{l}-0.0382 \\
(0.22)\end{array}$ & $\begin{array}{l}0.0013 \\
(0.01)\end{array}$ & $\begin{array}{l}0.0179 \\
(0.11)\end{array}$ & $\begin{array}{l}-0.0096 \\
(0.05)\end{array}$ & $\begin{array}{l}0.2749 \\
(0.77)\end{array}$ & $\begin{array}{l}0.3078 \\
(0.85)\end{array}$ \\
\hline Age: $18-64$ years & $\begin{array}{l}0.5271 \\
(2.48)^{* *}\end{array}$ & $\begin{array}{l}0.7409 \\
(2.83)^{*}\end{array}$ & $\begin{array}{l}0.1798 \\
(1.69) * * *\end{array}$ & $\begin{array}{l}0.1769 \\
(1.62)\end{array}$ & $\begin{array}{l}0.1244 \\
(0.81)\end{array}$ & $\begin{array}{l}0.1254 \\
(0.78)\end{array}$ & $\begin{array}{l}0.2585 \\
(2.21)^{* *}\end{array}$ & $\begin{array}{l}0.2224 \\
(1.85)^{* * *}\end{array}$ & $\begin{array}{l}-0.0292 \\
(0.10)\end{array}$ & $\begin{array}{l}-0.0219 \\
(0.07)\end{array}$ \\
\hline Age: $65+$ & $\begin{array}{l}0.3343 \\
(1.89)^{* * *}\end{array}$ & $\begin{array}{l}0.4406 \\
(1.97)^{* * *}\end{array}$ & $\begin{array}{l}0.1669 \\
(1.55)\end{array}$ & $\begin{array}{l}0.1748 \\
(1.58)\end{array}$ & $\begin{array}{l}0.0601 \\
(0.46)\end{array}$ & $\begin{array}{l}0.0613 \\
(0.45)\end{array}$ & $\begin{array}{l}0.1964 \\
(1.56)\end{array}$ & $\begin{array}{l}0.1433 \\
(1.12)\end{array}$ & $\begin{array}{l}0.1607 \\
(0.57)\end{array}$ & $\begin{array}{l}0.0658 \\
(0.24)\end{array}$ \\
\hline Blacks & $\begin{array}{l}0.0451 \\
(0.16)\end{array}$ & $\begin{array}{l}0.0828 \\
(0.24)\end{array}$ & $\begin{array}{l}-0.0461 \\
(1.91)^{* * *}\end{array}$ & $\begin{array}{l}-0.0345 \\
(1.44)\end{array}$ & $\begin{array}{l}0.0013 \\
(0.11)\end{array}$ & $\begin{array}{l}0.0008 \\
(0.07)\end{array}$ & $\begin{array}{l}-0.0172 \\
(0.89)\end{array}$ & $\begin{array}{l}-0.0134 \\
(0.67)\end{array}$ & $\begin{array}{l}-0.0112 \\
(0.44)\end{array}$ & $\begin{array}{l}-0.0053 \\
(0.21)\end{array}$ \\
\hline Hispanic & $\begin{array}{l}-0.0493 \\
(0.12)\end{array}$ & $\begin{array}{l}-0.0278 \\
(0.05)\end{array}$ & $\begin{array}{l}-0.0123 \\
(0.32)\end{array}$ & $\begin{array}{l}-0.0174 \\
(0.44)\end{array}$ & $\begin{array}{l}0.0664 \\
(1.73)^{* * *}\end{array}$ & $\begin{array}{l}0.0807 \\
(2.04)^{* *}\end{array}$ & $\begin{array}{l}0.0560 \\
(0.27)\end{array}$ & $\begin{array}{l}0.1219 \\
(0.56)\end{array}$ & $\begin{array}{l}0.4741 \\
(0.71)\end{array}$ & $\begin{array}{l}0.2112 \\
(0.33)\end{array}$ \\
\hline Education: 9-11 years & $\begin{array}{l}-0.0456 \\
(1.03)\end{array}$ & $\begin{array}{l}0.0309 \\
(0.62)\end{array}$ & $\begin{array}{l}0.0251 \\
(0.89)\end{array}$ & $\begin{array}{l}0.0171 \\
(0.60)\end{array}$ & $\begin{array}{l}-0.0037 \\
(0.11)\end{array}$ & $\begin{array}{l}-0.0018 \\
(0.05)\end{array}$ & $\begin{array}{l}0.0001 \\
(0.01)\end{array}$ & $\begin{array}{l}-0.0021 \\
(0.07)\end{array}$ & $\begin{array}{l}-0.0157 \\
(0.33)\end{array}$ & $\begin{array}{l}-0.0098 \\
(0.20)\end{array}$ \\
\hline Education: H.S. diploma & $\begin{array}{l}-0.0371 \\
(1.13)\end{array}$ & $\begin{array}{l}-0.0729 \\
(1.82)^{* * *}\end{array}$ & $\begin{array}{l}-0.0332 \\
(2.01)^{* *}\end{array}$ & $\begin{array}{l}-0.0317 \\
(1.87)^{* * *}\end{array}$ & $\begin{array}{l}0.0409 \\
(1.79)^{* * *}\end{array}$ & $\begin{array}{l}0.0556 \\
(2.43)^{* *}\end{array}$ & $\begin{array}{l}-0.0233 \\
(1.13)\end{array}$ & $\begin{array}{l}-0.0033 \\
(1.59)\end{array}$ & $\begin{array}{l}-0.0831 \\
(1.10)\end{array}$ & $\begin{array}{l}-0.1084 \\
(1.48)\end{array}$ \\
\hline Education: Some college & $\begin{array}{l}0.1252 \\
(2.31)^{* *}\end{array}$ & $\begin{array}{l}0.1838 \\
(2.78)^{* *}\end{array}$ & $\begin{array}{l}0.1058 \\
(2.10)^{* *}\end{array}$ & $\begin{array}{l}0.1305 \\
(2.62)^{* *}\end{array}$ & $\begin{array}{l}0.0302 \\
(0.61)\end{array}$ & $\begin{array}{l}0.0728 \\
(1.54)\end{array}$ & $\begin{array}{l}0.0041 \\
(0.07)\end{array}$ & $\begin{array}{l}0.0121 \\
(0.20)\end{array}$ & $\begin{array}{l}0.0561 \\
(0.29)\end{array}$ & $\begin{array}{l}0.1236 \\
(0.66)\end{array}$ \\
\hline Education: Bachelor + & $\begin{array}{l}-0.0453 \\
(0.53)\end{array}$ & $\begin{array}{l}0.1245 \\
(1.35)\end{array}$ & $\begin{array}{l}0.0602 \\
(1.40)\end{array}$ & $\begin{array}{l}0.0691 \\
(1.58)\end{array}$ & $\begin{array}{l}0.0251 \\
(0.67)\end{array}$ & $\begin{array}{l}0.0230 \\
(0.59)\end{array}$ & $\begin{array}{l}0.1638 \\
(3.27)^{*}\end{array}$ & $\begin{array}{c}0.2049 \\
(4.32)^{*}\end{array}$ & $\begin{array}{l}-0.0493 \\
(0.26)\end{array}$ & $\begin{array}{l}0.0301 \\
(0.17)\end{array}$ \\
\hline Housing & $\begin{array}{l}-0.0000 \\
(0.07)\end{array}$ & $\begin{array}{l}-0.0000 \\
(0.69)\end{array}$ & $\begin{array}{l}0.0000 \\
(1.67)^{* * *}\end{array}$ & $\begin{array}{l}0.0000 \\
(1.70)^{* * * *}\end{array}$ & $\begin{array}{l}0.0000 \\
(0.86)\end{array}$ & $\begin{array}{l}0.0000 \\
(1.07)\end{array}$ & $\begin{array}{l}0.0000 \\
(1.17)\end{array}$ & $\begin{array}{l}0.0000 \\
(1.12)\end{array}$ & $\begin{array}{l}0.0000 \\
(0.93)\end{array}$ & $\begin{array}{l}0.0000 \\
(1.35)\end{array}$ \\
\hline $\begin{array}{l}\text { Federal government } \\
\text { employment }\end{array}$ & $\begin{array}{l}0.1826 \\
(2.02)^{* * * *}\end{array}$ & $\begin{array}{l}0.2289 \\
(2.00)^{* * *}\end{array}$ & $\begin{array}{l}-0.0303 \\
(0.54)\end{array}$ & $\begin{array}{l}-0.0232 \\
(0.41)\end{array}$ & $\begin{array}{l}-0.1119 \\
(2.22)^{* *}\end{array}$ & $\begin{array}{l}-0.1022 \\
(1.95)^{* * *}\end{array}$ & $\begin{array}{l}0.0185 \\
(0.31)\end{array}$ & $\begin{array}{l}0.0167 \\
(0.27)\end{array}$ & $\begin{array}{l}-0.0208 \\
(0.26)\end{array}$ & $\begin{array}{l}-0.0164 \\
(0.20)\end{array}$ \\
\hline $\begin{array}{l}\text { State government } \\
\text { employment }\end{array}$ & $\begin{array}{l}0.1464 \\
(2.26)^{* *}\end{array}$ & $\begin{array}{l}0.1278 \\
(1.55)\end{array}$ & $\begin{array}{l}-0.0195 \\
(0.82)\end{array}$ & $\begin{array}{l}-0.0318 \\
(1.35)\end{array}$ & $\begin{array}{l}-0.0514 \\
(1.52)\end{array}$ & $\begin{array}{l}-0.0642 \\
(1.84)^{* * *}\end{array}$ & $\begin{array}{l}0.0251 \\
(0.99)\end{array}$ & $\begin{array}{l}0.0252 \\
(0.96)\end{array}$ & $\begin{array}{l}-0.0388 \\
(0.39)\end{array}$ & $\begin{array}{l}-0.0734 \\
(1.76)^{* * *}\end{array}$ \\
\hline $\begin{array}{l}\text { Local government } \\
\text { employment }\end{array}$ & $\begin{array}{l}0.2179 \\
(2.93)^{*}\end{array}$ & $\begin{array}{l}0.2417 \\
(2.55)^{* *}\end{array}$ & $\begin{array}{l}-0.0414 \\
(0.88)\end{array}$ & $\begin{array}{l}-0.0202 \\
(0.43)\end{array}$ & $\begin{array}{l}-0.0882 \\
(2.51)^{* *}\end{array}$ & $\begin{array}{l}-0.0902 \\
(2.46)^{* *}\end{array}$ & $\begin{array}{l}-0.1254 \\
(2.12)^{* *}\end{array}$ & $\begin{array}{l}-0.1365 \\
(2.22)^{* *}\end{array}$ & $\begin{array}{l}-0.0224 \\
(0.21)\end{array}$ & $\begin{array}{l}-0.0184 \\
(0.17)\end{array}$ \\
\hline Self-employment & $\begin{array}{l}0.0702 \\
(1.30)\end{array}$ & $\begin{array}{l}0.0334 \\
(0.49)\end{array}$ & $\begin{array}{l}0.0046 \\
(0.11)\end{array}$ & $\begin{array}{l}-0.0148 \\
(0.34)\end{array}$ & $\begin{array}{l}0.0716 \\
(2.28)^{* *}\end{array}$ & $\begin{array}{l}0.0622 \\
(1.92)^{* * *}\end{array}$ & $\begin{array}{l}0.0103 \\
(0.20)\end{array}$ & $\begin{array}{l}0.0325 \\
(0.61)\end{array}$ & $\begin{array}{l}-0.0104 \\
(0.09)\end{array}$ & $\begin{array}{l}-0.0169 \\
(0.15)\end{array}$ \\
\hline Agriculture & $\begin{array}{l}0.1938 \\
(1.84)^{* * *}\end{array}$ & $\begin{array}{l}0.3063 \\
(2.37)^{* *}\end{array}$ & $\begin{array}{l}-0.0322 \\
(0.39)\end{array}$ & $\begin{array}{l}0.0085 \\
(0.10)\end{array}$ & $\begin{array}{l}-0.1672 \\
(2.74)^{*}\end{array}$ & $\begin{array}{l}-0.1393 \\
(2.24)^{* *}\end{array}$ & $\begin{array}{l}-0.0197 \\
(0.24)\end{array}$ & $\begin{array}{l}-0.0474 \\
(0.56)\end{array}$ & $\begin{array}{l}-0.1160 \\
(0.64)\end{array}$ & $\begin{array}{l}-0.1625 \\
(0.92)\end{array}$ \\
\hline Communications & $\begin{array}{l}0.3453 \\
(3.03)^{*}\end{array}$ & $\begin{array}{l}0.4596 \\
(3.28)^{*}\end{array}$ & $\begin{array}{l}-0.0814 \\
(0.93)\end{array}$ & $\begin{array}{l}-0.0735 \\
(0.82)\end{array}$ & $\begin{array}{l}-0.1286 \\
(1.96)^{* * *}\end{array}$ & $\begin{array}{l}-0.1157 \\
(1.69)^{* * *}\end{array}$ & $\begin{array}{l}0.0699 \\
(0.72)\end{array}$ & $\begin{array}{l}0.0819 \\
(0.82)\end{array}$ & $\begin{array}{l}0.0621 \\
(0.23)\end{array}$ & $\begin{array}{l}0.1133 \\
(0.42)\end{array}$ \\
\hline Construction & $\begin{array}{l}0.2171 \\
(2.45)^{* *}\end{array}$ & $\begin{array}{l}0.2746 \\
(2.46)^{* *}\end{array}$ & $\begin{array}{l}-0.0134 \\
(0.18)\end{array}$ & $\begin{array}{l}0.0148 \\
(0.20)\end{array}$ & $\begin{array}{l}-0.0694 \\
(1.31)\end{array}$ & $\begin{array}{l}-0.0471 \\
(0.86)\end{array}$ & $\begin{array}{l}0.0297 \\
(0.44)\end{array}$ & $\begin{array}{l}0.0198 \\
(0.28)\end{array}$ & $\begin{array}{l}-0.1362 \\
(0.75)\end{array}$ & $\begin{array}{l}-0.1448 \\
(0.79)\end{array}$ \\
\hline $\begin{array}{l}\text { Finance, insurance } \\
\& \text { real estate }\end{array}$ & $\begin{array}{l}0.5413 \\
(3.26)^{*}\end{array}$ & $\begin{array}{l}0.7250 \\
(3.57)^{*}\end{array}$ & $\begin{array}{l}-0.0666 \\
(0.66)\end{array}$ & $\begin{array}{l}-0.0284 \\
(0.28)\end{array}$ & $\begin{array}{l}-0.1282 \\
(1.59)\end{array}$ & $\begin{array}{l}-0.0913 \\
(1.11)\end{array}$ & $\begin{array}{l}-0.0628 \\
(0.67)\end{array}$ & $\begin{array}{l}-0.0515 \\
(0.53)\end{array}$ & $\begin{array}{l}-0.0310 \\
(0.09)\end{array}$ & $\begin{array}{l}-0.1886 \\
(0.55)\end{array}$ \\
\hline $\begin{array}{l}\text { Manufacturing - } \\
\text { durables }\end{array}$ & $\begin{array}{l}0.3316 \\
(3.57)^{*}\end{array}$ & $\begin{array}{l}0.4189 \\
(3.65)^{*}\end{array}$ & $\begin{array}{l}-0.0457 \\
(0.69)\end{array}$ & $\begin{array}{l}-0.0261 \\
(0.39)\end{array}$ & $\begin{array}{l}-0.0951 \\
(1.82)^{* * *}\end{array}$ & $\begin{array}{l}-0.0836 \\
(1.54)\end{array}$ & $\begin{array}{l}-0.0016 \\
(0.03)\end{array}$ & $\begin{array}{l}-0.0092 \\
(0.15)\end{array}$ & $\begin{array}{l}-0.0899 \\
(0.53)\end{array}$ & $\begin{array}{l}-0.1359 \\
(0.82)\end{array}$ \\
\hline
\end{tabular}


Referee Appendix Table 5: Entire United States

\begin{tabular}{|c|c|c|c|c|c|c|c|c|c|c|}
\hline \multirow[b]{2}{*}{$\underline{\text { RHS Variables }^{15}}$} & \multicolumn{2}{|c|}{ __North Dakota_ } & \multicolumn{2}{|c|}{ Ohio } & \multicolumn{2}{|c|}{ _ Oklahoma } & \multicolumn{2}{|c|}{ _Pennsylvania } & \multicolumn{2}{|c|}{ _South Carolina } \\
\hline & $\underline{\text { OLS }}$ & $\underline{2 S L S}$ & $\underline{\text { OLS }}$ & $\underline{2 S L S}$ & $\underline{\text { OLS }}$ & $\underline{2 S L S}$ & $\underline{\text { OLS }}$ & $\underline{2 S L S}$ & $\underline{\text { OLS }}$ & $\underline{2 S L S}$ \\
\hline $\begin{array}{l}\text { Manufacturing - } \\
\text { nondurables }\end{array}$ & $\begin{array}{l}0.4186 \\
(3.03)^{*}\end{array}$ & $\begin{array}{l}0.5928 \\
(3.57)^{*}\end{array}$ & $\begin{array}{l}-0.0538 \\
(0.86)\end{array}$ & $\begin{array}{l}-0.0341 \\
(0.54)\end{array}$ & $\begin{array}{l}-0.1051 \\
(2.13)^{* *}\end{array}$ & $\begin{array}{l}-0.0902 \\
(1.77)^{* * *}\end{array}$ & $\begin{array}{l}0.0011 \\
(0.02)\end{array}$ & $\begin{array}{l}-0.0118 \\
(0.20)\end{array}$ & $\begin{array}{l}-0.1061 \\
(0.62)\end{array}$ & $\begin{array}{l}-0.1642 \\
(1.00)\end{array}$ \\
\hline Mining & $\begin{array}{l}0.2029 \\
(2.00)^{* * *}\end{array}$ & $\begin{array}{l}0.3108 \\
(2.50)^{* *}\end{array}$ & $\begin{array}{l}-0.0693 \\
(1.03)\end{array}$ & $\begin{array}{l}-0.0474 \\
(0.70)\end{array}$ & $\begin{array}{l}-0.1035 \\
(1.86) * * *\end{array}$ & $\begin{array}{l}-0.0794 \\
(1.39)\end{array}$ & $\begin{array}{l}0.0275 \\
(0.42)\end{array}$ & $\begin{array}{l}0.0133 \\
(0.19)\end{array}$ & $\begin{array}{l}-0.1625 \\
(0.33)\end{array}$ & $\begin{array}{l}-0.2692 \\
(0.55)\end{array}$ \\
\hline Retail & $\begin{array}{l}0.2733 \\
(2.73)^{* *}\end{array}$ & $\begin{array}{l}0.3688 \\
(2.98)^{*}\end{array}$ & $\begin{array}{l}-0.0727 \\
(1.05)\end{array}$ & $\begin{array}{l}-0.0475 \\
(0.69)\end{array}$ & $\begin{array}{l}-0.1534 \\
(2.66)^{* *}\end{array}$ & $\begin{array}{l}-0.1521 \\
(2.52)^{* *}\end{array}$ & $\begin{array}{l}-0.0387 \\
(0.62)\end{array}$ & $\begin{array}{l}-0.0528 \\
(0.82)\end{array}$ & $\begin{array}{l}-0.0314 \\
(0.17)\end{array}$ & $\begin{array}{l}-0.0868 \\
(0.47)\end{array}$ \\
\hline $\begin{array}{l}\text { Business \& repair } \\
\text { services }\end{array}$ & $\begin{array}{l}0.2177 \\
(1.59)\end{array}$ & $\begin{array}{l}0.1469 \\
(0.85)\end{array}$ & $\begin{array}{l}-0.1216 \\
(0.94)\end{array}$ & $\begin{array}{l}-0.0871 \\
(0.67)\end{array}$ & $\begin{array}{l}-0.1544 \\
(1.42)\end{array}$ & $\begin{array}{l}-0.1851 \\
(1.65)\end{array}$ & $\begin{array}{l}-0.0039 \\
(0.03)\end{array}$ & $\begin{array}{l}-0.0182 \\
(0.15)\end{array}$ & $\begin{array}{l}0.3402 \\
(0.82)\end{array}$ & $\begin{array}{l}0.2742 \\
(0.66)\end{array}$ \\
\hline Educational services & $\begin{array}{l}0.0470 \\
(0.40)\end{array}$ & $\begin{array}{l}0.0900 \\
(0.60)\end{array}$ & $\begin{array}{l}0.0362 \\
(0.38)\end{array}$ & $\begin{array}{l}0.0345 \\
(0.35)\end{array}$ & $\begin{array}{l}0.1086 \\
(1.42)\end{array}$ & $\begin{array}{l}0.0991 \\
(1.24)\end{array}$ & $\begin{array}{l}-0.1538 \\
(1.22)\end{array}$ & $\begin{array}{l}-0.1111 \\
(0.86)\end{array}$ & $\begin{array}{l}0.1611 \\
(0.45)\end{array}$ & $\begin{array}{l}0.1143 \\
(0.32)\end{array}$ \\
\hline $\begin{array}{l}\text { Professional related } \\
\text { services }\end{array}$ & $\begin{array}{l}0.0462 \\
(0.37)\end{array}$ & $\begin{array}{l}-0.0381 \\
(0.24)\end{array}$ & $\begin{array}{l}-0.0705 \\
(0.69)\end{array}$ & $\begin{array}{l}-0.0583 \\
(0.56)\end{array}$ & $\begin{array}{l}-0.1505 \\
(1.85)^{* * *}\end{array}$ & $\begin{array}{l}-0.1237 \\
(1.48)\end{array}$ & $\begin{array}{l}0.0284 \\
(0.18)\end{array}$ & $\begin{array}{l}-0.0526 \\
(0.33)\end{array}$ & $\begin{array}{l}-0.1690 \\
(0.48)\end{array}$ & $\begin{array}{l}-0.2403 \\
(0.68)\end{array}$ \\
\hline Health services & $\begin{array}{l}0.1797 \\
(1.32)\end{array}$ & $\begin{array}{l}0.3786 \\
(2.36)^{* *}\end{array}$ & $\begin{array}{l}0.0055 \\
(0.06)\end{array}$ & $\begin{array}{l}0.0115 \\
(0.12)\end{array}$ & $\begin{array}{l}0.0751 \\
(1.06)\end{array}$ & $\begin{array}{l}0.0833 \\
(1.13)\end{array}$ & $\begin{array}{l}-0.0043 \\
(0.03)\end{array}$ & $\begin{array}{l}0.0623 \\
(0.49)\end{array}$ & $\begin{array}{l}-0.0615 \\
(0.14)\end{array}$ & $\begin{array}{l}-0.0945 \\
(0.22)\end{array}$ \\
\hline Personal services & $\begin{array}{l}0.3575 \\
(2.76)^{* *}\end{array}$ & $\begin{array}{l}0.4887 \\
(3.07)^{*}\end{array}$ & $\begin{array}{l}0.1178 \\
(1.28)\end{array}$ & $\begin{array}{l}0.1560 \\
(1.69)^{* * *}\end{array}$ & $\begin{array}{l}-0.1594 \\
(2.09)^{* *}\end{array}$ & $\begin{array}{l}-0.1709 \\
(2.15)^{* *}\end{array}$ & $\begin{array}{l}-0.0788 \\
(0.88)\end{array}$ & $\begin{array}{l}-0.0864 \\
(0.93)\end{array}$ & $\begin{array}{l}-0.0612 \\
(0.29)\end{array}$ & $\begin{array}{l}-0.1066 \\
(0.50)\end{array}$ \\
\hline $\begin{array}{l}\text { Entertainment \& } \\
\text { recreational services }\end{array}$ & $\begin{array}{c}0.5566 \\
(3.00)^{*}\end{array}$ & $\begin{array}{l}0.7627 \\
(3.37)^{*}\end{array}$ & $\begin{array}{l}0.2041 \\
(0.97)\end{array}$ & $\begin{array}{l}0.2109 \\
(0.98)\end{array}$ & $\begin{array}{l}-0.2447 \\
(1.17)\end{array}$ & $\begin{array}{l}-0.2212 \\
(1.01)\end{array}$ & $\begin{array}{l}0.3019 \\
(0.88)\end{array}$ & $\begin{array}{l}0.3957 \\
(1.12)\end{array}$ & $\begin{array}{l}-0.2259 \\
(0.49)\end{array}$ & $\begin{array}{l}-0.2122 \\
(0.45)\end{array}$ \\
\hline Transportation & $\begin{array}{l}0.2914 \\
(2.59)^{* *}\end{array}$ & $\begin{array}{l}0.3771 \\
(2.67)^{* *}\end{array}$ & $\begin{array}{l}-0.0695 \\
(0.96)\end{array}$ & $\begin{array}{l}-0.0479 \\
(0.66)\end{array}$ & $\begin{array}{l}-0.0831 \\
(1.11)\end{array}$ & $\begin{array}{l}-0.0808 \\
(1.03)\end{array}$ & $\begin{array}{l}0.0452 \\
(0.67)\end{array}$ & $\begin{array}{l}0.0288 \\
(0.41)\end{array}$ & $\begin{array}{l}-0.1319 \\
(0.61)\end{array}$ & $\begin{array}{l}-0.2140 \\
(1.04)\end{array}$ \\
\hline Wholesale trade & $\begin{array}{l}0.1758 \\
(1.58)\end{array}$ & $\begin{array}{l}0.2107 \\
(1.49)\end{array}$ & $\begin{array}{l}0.0445 \\
(0.52)\end{array}$ & $\begin{array}{l}0.0580 \\
(0.67)\end{array}$ & $\begin{array}{l}-0.0351 \\
(0.39)\end{array}$ & $\begin{array}{l}-0.0143 \\
(0.15)\end{array}$ & $\begin{array}{l}-0.0249 \\
(0.27)\end{array}$ & $\begin{array}{l}-0.0055 \\
(0.06)\end{array}$ & $\begin{array}{l}-0.2581 \\
(0.87)\end{array}$ & $\begin{array}{l}-0.3619 \\
(1.27)\end{array}$ \\
\hline Poverty & $\begin{array}{l}-0.0083 \\
(0.26)\end{array}$ & $\begin{array}{l}0.0011 \\
(0.03)\end{array}$ & $\begin{array}{l}-0.0220 \\
(0.77)\end{array}$ & $\begin{array}{l}-0.0578 \\
(2.65)^{* *}\end{array}$ & $\begin{array}{l}0.0075 \\
(0.38)\end{array}$ & $\begin{array}{l}-0.0122 \\
(0.67)\end{array}$ & $\begin{array}{l}0.0010 \\
(0.03)\end{array}$ & $\begin{array}{l}-0.0280 \\
(0.83)\end{array}$ & $\begin{array}{l}-0.0487 \\
(0.75)\end{array}$ & $\begin{array}{l}-0.0903 \\
(1.66)\end{array}$ \\
\hline Metro area, 1970 & $\begin{array}{l}0.0000 \\
(0.00)\end{array}$ & $\begin{array}{l}0.0000 \\
(0.00)\end{array}$ & $\begin{array}{l}0.0012 \\
(1.18)\end{array}$ & $\begin{array}{l}0.0015 \\
(1.46)\end{array}$ & $\begin{array}{l}-0.0012 \\
(0.90)\end{array}$ & $\begin{array}{l}-0.0009 \\
(0.63)\end{array}$ & $\begin{array}{l}-0.0000 \\
(0.07)\end{array}$ & $\begin{array}{l}-0.0001 \\
(0.11)\end{array}$ & $\begin{array}{l}0.0002 \\
(0.08)\end{array}$ & $\begin{array}{l}0.4611 \\
(1.35)\end{array}$ \\
\hline $\begin{array}{l}\mathrm{R}^{2} \\
\text { Adjusted } \mathrm{R}^{2} \\
\text { \# Observations }\end{array}$ & $\begin{array}{l}0.90 \\
0.73 \\
53\end{array}$ & $\begin{array}{l}0.91 \\
0.78 \\
53\end{array}$ & $\begin{array}{l}0.74 \\
0.57 \\
88\end{array}$ & $\begin{array}{l}0.89 \\
0.83 \\
88\end{array}$ & $\begin{array}{l}0.78 \\
0.61 \\
77\end{array}$ & $\begin{array}{l}0.89 \\
0.81 \\
77\end{array}$ & $\begin{array}{l}67 \\
0.81 \\
0.61\end{array}$ & $\begin{array}{l}67 \\
0.93 \\
0.86\end{array}$ & $\begin{array}{l}46 \\
072 \\
0.70\end{array}$ & $\begin{array}{l}46 \\
0.92 \\
0.73\end{array}$ \\
\hline
\end{tabular}

${ }_{15}$ All RHS variables are initial values from 1970. 
RHS Variables $^{16}$

Constant

Log 1970 per capita income $^{17}$

Age: 5-13 years

Age: $14-17$ years

Age: $18-64$ years

Age: $65+$

Blacks

Hispanic

Education: 9-11 years

Education: H.S. diploma

Education: Some college

Education: Bachelor +

Housing

Federal government employment

State government

employment

Local government employment

Self-employment

Agriculture

Communications

Construction

Finance, insurance $\&$ real estate

Manufacturing durables

\begin{tabular}{|c|c|c|c|c|c|c|c|c|c|}
\hline \multicolumn{2}{|c|}{ _South Dakota } & \multicolumn{2}{|c|}{ Tennessee_ } & \multicolumn{2}{|c|}{ Texas _ } & \multicolumn{2}{|c|}{ Virginia__ } & \multicolumn{2}{|c|}{ Washington } \\
\hline I & $\underline{2 \mathrm{SLS}}$ & $\underline{\text { OLS }}$ & $\underline{2 S L S}$ & $\underline{S}$ & $\underline{2 S L S}$ & $S$ & SLS & LS & SLS \\
\hline .23 & $\begin{array}{l}0.0 \\
(0.0\end{array}$ & $(0.2$ & $(1.3$ & 37 & $(5.6$ & $\begin{array}{l}0.0922 \\
(0.85)\end{array}$ & $\begin{array}{r}0.3 \\
(3.1\end{array}$ & $\begin{array}{c}0.0 \\
(0.1\end{array}$ & $\begin{array}{l}0.0594 \\
(0.10)\end{array}$ \\
\hline 22 & $\begin{array}{l}-0.0 \\
(4.7\end{array}$ & $\begin{array}{l}-0.0 \\
(3.5\end{array}$ & $\begin{array}{l}-0.0 \\
(15.2\end{array}$ & 1 & $\begin{array}{l}-0.0 \\
(15 .\end{array}$ & 45 & $\begin{array}{l}-0.0 \\
(15\end{array}$ & 49 & $\begin{array}{l}-0.0327 \\
(9.29)^{*}\end{array}$ \\
\hline 0 & $\begin{array}{l}0.5227 \\
(2.98)^{*}\end{array}$ & $\begin{array}{l}0.1158 \\
(0.80)\end{array}$ & $\begin{array}{l}0.1347 \\
(0.86)\end{array}$ & & $\begin{array}{l}-0.0224 \\
(0.32)\end{array}$ & $\begin{array}{l}.0098 \\
.08)\end{array}$ & 0.0 & & $\begin{array}{l}0.4183 \\
(0.47)\end{array}$ \\
\hline $\begin{array}{c}0.2482 \\
(167)\end{array}$ & $\begin{array}{c}0.2632 \\
(1.79)^{* * *}\end{array}$ & $\begin{array}{l}0.0766 \\
(0.63)\end{array}$ & $\begin{array}{r}0.1 \\
(0.8\end{array}$ & 36 & $\begin{array}{l}-0.0134 \\
(0.21)\end{array}$ & 04 & $\begin{array}{l}0.0346 \\
(0.27)\end{array}$ & ) & $\begin{array}{l}0.2310 \\
(0.34)\end{array}$ \\
\hline $\begin{array}{l}601 \\
2)^{* * *}\end{array}$ & $\begin{array}{c}0.2906 \\
(1.98)^{* * *}\end{array}$ & $\begin{array}{l}0.0391 \\
(0.34)\end{array}$ & $\begin{array}{l}0.0795 \\
(0.63)\end{array}$ & & $\begin{array}{l}-0.0245 \\
(0.44)\end{array}$ & & & & \\
\hline & $\begin{array}{l}0.3334 \\
(2.91)^{*}\end{array}$ & $\begin{array}{l}0.11 \\
(1.07\end{array}$ & 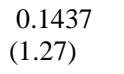 & & $\begin{array}{l}-0.0672 \\
(1.44)\end{array}$ & & 0. & & 149) \\
\hline 1 & $\begin{array}{l}-0.1344 \\
(0.58)\end{array}$ & $\begin{array}{r}0.01 \\
(1.28\end{array}$ & & & $\begin{array}{l}-0.0038 \\
(0.51)\end{array}$ & & .16) & & $\begin{array}{l}-0.0984 \\
(0.53)\end{array}$ \\
\hline & $(0.76)$ & $\begin{array}{c}0.6294 \\
(2.29)^{* *}\end{array}$ & & & $\begin{array}{l}-0.0174 \\
(2.71)^{*}\end{array}$ & & & & $\begin{array}{l}0.0886 \\
(0.88)\end{array}$ \\
\hline $\begin{array}{l}-0.0949 \\
(2.66)^{* *}\end{array}$ & $\begin{array}{l}-0.09 \text { ( } \\
(2.57)\end{array}$ & $\begin{array}{l}-0.0098 \\
(0.36)\end{array}$ & $\begin{array}{l}0 .( \\
(0 .\end{array}$ & & $\begin{array}{l}-0.0594 \\
(4.85)^{*}\end{array}$ & & 8) & & $\begin{array}{l}0.0307 \\
(0.21)\end{array}$ \\
\hline $\begin{array}{l}0 \\
(0\end{array}$ & $\begin{array}{c}0 \\
(0\end{array}$ & $\begin{array}{r}0.0 \\
(0.2\end{array}$ & & & $\begin{array}{c}0 \\
(0\end{array}$ & & & & \\
\hline 0. & $\begin{array}{l}0 \\
(0\end{array}$ & $\begin{array}{l}-0.0 \\
(1.1\end{array}$ & & & $\begin{array}{l}0.0282 \\
(1.28)\end{array}$ & & & & $\begin{array}{l}0 . \\
(0 .\end{array}$ \\
\hline 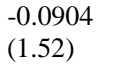 & $(1$ & $\begin{array}{r}0.1 \\
(2.1\end{array}$ & 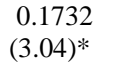 & & $\begin{array}{l}-0.0175 \\
(0.70)\end{array}$ & & & & $\begin{array}{c}0.1 \\
(0.9\end{array}$ \\
\hline 0 & $\begin{array}{l}0 \\
(0\end{array}$ & 0 & & & $\begin{array}{r}0.0 \\
(0.7\end{array}$ & *** & $\begin{array}{l}000 \\
3)\end{array}$ & & $\begin{array}{r}0 . \\
(1 .\end{array}$ \\
\hline$(0.69$ & $\begin{array}{l}-0 \\
(1\end{array}$ & $(0$. & $(0$ & & $(0$. & & $\begin{array}{l}166 \\
2)\end{array}$ & & 42) \\
\hline 0 & $(($ & $\begin{array}{l}-0 \\
(1\end{array}$ & ** & $\begin{array}{l}0 \\
(0\end{array}$ & 21 & & & & $\begin{array}{l}-0.0691 \\
(0.57)\end{array}$ \\
\hline- & $\begin{array}{l}-0.05 \\
(1.23\end{array}$ & $\begin{array}{r}0.0 \\
(0.1\end{array}$ & $\begin{array}{l}0 . \\
(0 .\end{array}$ & & $\begin{array}{l}-0 \\
(1\end{array}$ & 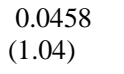 & 4) & 3 & $\begin{array}{l}-0 \\
(0\end{array}$ \\
\hline 0 & 0 & 0 & 6 & & 99 & & & & $\begin{array}{l}0.0015 \\
(0.02)\end{array}$ \\
\hline-0.10 & $\begin{array}{l}-0.10 \\
(1.6\end{array}$ & 0 & 0 & 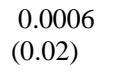 & 9 & \% & 3) & $\begin{array}{l}914 \\
0)\end{array}$ & $\begin{array}{l}-0.09 \\
(0.83\end{array}$ \\
\hline-0.2021 & $\begin{array}{l}-0.1912 \\
(1.49)\end{array}$ & $\begin{array}{l}0.0 \\
(0.8\end{array}$ & $\begin{array}{c}0 . \\
(1 .\end{array}$ & $\begin{array}{l}123 \\
7)^{* *}\end{array}$ & $\begin{array}{l}-0.0893 \\
(1.85)^{* * *}\end{array}$ & $\begin{array}{l}-0.0719 \\
(0.97)\end{array}$ & 44 & 75 & $\begin{array}{l}0.0490 \\
(0.36)\end{array}$ \\
\hline 05 & $\begin{array}{l}-0.0561 \\
(0.64)\end{array}$ & $\begin{array}{l}1412 \\
31)^{* *}\end{array}$ & 80 & 0 & $\begin{array}{l}0.0471 \\
(1.21)\end{array}$ & $\begin{array}{l}307 \\
8)\end{array}$ & $\begin{array}{l}389 \\
2)\end{array}$ & $\begin{array}{l}244 \\
2)\end{array}$ & $\begin{array}{l}0.0205 \\
(0.12)\end{array}$ \\
\hline $\begin{array}{l}0.0807 \\
(0.74)\end{array}$ & $\begin{array}{l}0.0785 \\
(0.72)\end{array}$ & $\begin{array}{l}0.27 \\
(2.5 t\end{array}$ & $\begin{array}{r}0.2 \\
(2.2\end{array}$ & $*$ & $\begin{array}{c}0.1834 \\
(3.27)^{*}\end{array}$ & 0.0 & 0.1706 & $\begin{array}{l}-0 . \\
(0 .\end{array}$ & $\begin{array}{l}-0.0328 \\
(0.12)\end{array}$ \\
\hline $\begin{array}{r}0.011 \\
(0.14\end{array}$ & $\begin{array}{l}0.0046 \\
(0.07)\end{array}$ & $\begin{array}{c}0.1112 \\
(1.93)^{*}\end{array}$ & $\begin{array}{c}0.1060 \\
(1.69)^{* * *}\end{array}$ & $\begin{array}{l}0.0075 \\
(0.22)\end{array}$ & $\begin{array}{l}0.0324 \\
(0.91)\end{array}$ & $\begin{array}{l}-0.0236 \\
(0.59)\end{array}$ & $\begin{array}{l}-0.0306 \\
(0.64)\end{array}$ & $\begin{array}{l}-0.0803 \\
(0.54)\end{array}$ & $\begin{array}{l}-0.0801 \\
(0.60)\end{array}$ \\
\hline
\end{tabular}

${ }^{16}$ All RHS variables are initial values from 1970.

${ }_{17}$ All dollar values are in real 1992 dollars. 
Referee Appendix Table 6: Entire United States

\begin{tabular}{|c|c|c|c|c|c|c|c|c|c|c|}
\hline \multirow[b]{2}{*}{$\underline{\text { RHS Variables }^{18}}$} & \multicolumn{2}{|c|}{ _South Dakota } & \multicolumn{2}{|c|}{ _Tennessee } & \multicolumn{2}{|c|}{-Texas _ _ } & \multicolumn{2}{|c|}{ Virginia___ } & \multicolumn{2}{|c|}{ Washington } \\
\hline & $\underline{\text { OLS }}$ & $\underline{2 S L S}$ & $\underline{\text { OLS }}$ & $\underline{2 S L S}$ & $\underline{\text { OLS }}$ & $\underline{2 S L S}$ & $\underline{\text { OLS }}$ & $\underline{2 S L S}$ & $\underline{\text { OLS }}$ & $\underline{2 S L S}$ \\
\hline $\begin{array}{l}\text { Manufacturing - } \\
\text { nondurables }\end{array}$ & $\begin{array}{l}-0.0821 \\
(0.85)\end{array}$ & $\begin{array}{l}-0.1054 \\
(1.13)\end{array}$ & $\begin{array}{l}0.0941 \\
(1.62)\end{array}$ & $\begin{array}{l}0.0870 \\
(1.38)\end{array}$ & $\begin{array}{l}-0.0229 \\
(0.68)\end{array}$ & $\begin{array}{l}-0.0011 \\
(0.03)\end{array}$ & $\begin{array}{l}-0.0313 \\
(0.76)\end{array}$ & $\begin{array}{l}-0.0319 \\
(0.65)\end{array}$ & $\begin{array}{l}-0.0937 \\
(0.52)\end{array}$ & $\begin{array}{l}-0.0969 \\
(0.62)\end{array}$ \\
\hline Mining & $\begin{array}{l}-0.0544 \\
(0.79)\end{array}$ & $\begin{array}{l}-0.0683 \\
(1.02)\end{array}$ & $\begin{array}{l}0.0565 \\
(0.91)\end{array}$ & $\begin{array}{l}0.0521 \\
(0.78)\end{array}$ & $\begin{array}{l}-0.0205 \\
(0.60)\end{array}$ & $\begin{array}{l}0.0066 \\
(0.18)\end{array}$ & $\begin{array}{l}-0.0216 \\
(0.49)\end{array}$ & $\begin{array}{l}-0.0173 \\
(0.32)\end{array}$ & $\begin{array}{l}0.0229 \\
(0.18)\end{array}$ & $\begin{array}{l}0.0249 \\
(0.23)\end{array}$ \\
\hline Retail & $\begin{array}{l}-0.0504 \\
(0.65)\end{array}$ & $\begin{array}{l}-0.0630 \\
(0.83)\end{array}$ & $\begin{array}{l}0.1449 \\
(2.12)^{* *}\end{array}$ & $\begin{array}{l}0.1581 \\
(2.14)^{* *}\end{array}$ & $\begin{array}{l}-0.0374 \\
(1.04)\end{array}$ & $\begin{array}{l}-0.0161 \\
(0.42)\end{array}$ & $\begin{array}{l}-0.0855 \\
(1.84) * * *\end{array}$ & $\begin{array}{l}-0.0893 \\
(1.59)\end{array}$ & $\begin{array}{l}-0.1136 \\
(0.61)\end{array}$ & $\begin{array}{l}-0.1112 \\
(0.68)\end{array}$ \\
\hline $\begin{array}{l}\text { Business \& repair } \\
\text { services }\end{array}$ & $\begin{array}{l}0.1221 \\
(1.01)\end{array}$ & $\begin{array}{l}0.1090 \\
(0.92)\end{array}$ & $\begin{array}{l}0.0947 \\
(1.55)\end{array}$ & $\begin{array}{l}0.0977 \\
(1.47)\end{array}$ & $\begin{array}{l}0.0530 \\
(0.94)\end{array}$ & $\begin{array}{l}0.1079 \\
(1.83)^{* * *}\end{array}$ & $\begin{array}{l}0.0165 \\
(0.13)\end{array}$ & $\begin{array}{l}-0.0314 \\
(0.21)\end{array}$ & $\begin{array}{l}-0.0946 \\
(0.42)\end{array}$ & $\begin{array}{l}-0.0943 \\
(0.47)\end{array}$ \\
\hline Educational services & $\begin{array}{l}0.0649 \\
(0.86)\end{array}$ & $\begin{array}{l}0.0651 \\
(0.86)\end{array}$ & $\begin{array}{l}0.1237 \\
(1.34)\end{array}$ & $\begin{array}{l}0.0989 \\
(0.99)\end{array}$ & $\begin{array}{l}0.0061 \\
(0.15)\end{array}$ & $\begin{array}{l}-0.0347 \\
(0.80)\end{array}$ & $\begin{array}{l}-0.1828 \\
(2.05)^{* *}\end{array}$ & $\begin{array}{l}-0.1852 \\
(1.73)^{* * *}\end{array}$ & $\begin{array}{l}0.2693 \\
(0.72)\end{array}$ & $\begin{array}{l}0.2860 \\
(1.16)\end{array}$ \\
\hline $\begin{array}{l}\text { Professional related } \\
\text { services }\end{array}$ & $\begin{array}{l}-0.0298 \\
(0.29)\end{array}$ & $\begin{array}{l}-0.0434 \\
(0.44)\end{array}$ & $\begin{array}{l}0.0067 \\
(0.07)\end{array}$ & $\begin{array}{l}0.0126 \\
(0.12)\end{array}$ & $\begin{array}{l}-0.0363 \\
(0.72)\end{array}$ & $\begin{array}{l}0.0179 \\
(0.34)\end{array}$ & $\begin{array}{l}0.1071 \\
(1.29)\end{array}$ & $\begin{array}{l}0.0931 \\
(0.93)\end{array}$ & $\begin{array}{l}-0.3770 \\
(0.88)\end{array}$ & $\begin{array}{l}-0.3947 \\
(1.31)\end{array}$ \\
\hline Health services & $\begin{array}{l}0.0056 \\
(0.29)\end{array}$ & $\begin{array}{l}0.0115 \\
(0.16)\end{array}$ & $\begin{array}{l}0.1044 \\
(1.37)\end{array}$ & $\begin{array}{l}0.0787 \\
(0.96)\end{array}$ & $\begin{array}{l}0.0443 \\
(1.05)\end{array}$ & $\begin{array}{l}0.0364 \\
(0.81)\end{array}$ & $\begin{array}{l}-0.1005 \\
(1.15)\end{array}$ & $\begin{array}{l}-0.0846 \\
(0.80)\end{array}$ & $\begin{array}{l}0.4003 \\
(0.76)\end{array}$ & $\begin{array}{l}0.4279 \\
(1.49)\end{array}$ \\
\hline Personal services & $\begin{array}{l}0.0059 \\
(0.08)\end{array}$ & $\begin{array}{l}-0.0206 \\
(0.23)\end{array}$ & $\begin{array}{l}0.0624 \\
(0.78)\end{array}$ & $\begin{array}{l}0.0495 \\
(0.57)\end{array}$ & $\begin{array}{l}0.0388 \\
(0.98)\end{array}$ & $\begin{array}{l}0.0919 \\
(2.25)^{* *}\end{array}$ & $\begin{array}{l}0.0147 \\
(0.35)\end{array}$ & $\begin{array}{l}0.0233 \\
(0.46)\end{array}$ & $\begin{array}{l}-0.2745 \\
(1.25)\end{array}$ & $\begin{array}{l}-0.2739 \\
(1.39)\end{array}$ \\
\hline $\begin{array}{l}\text { Entertainment \& } \\
\text { recreational services }\end{array}$ & $\begin{array}{l}-0.0856 \\
(0.46)\end{array}$ & $\begin{array}{l}-0.1032 \\
(0.56)\end{array}$ & $\begin{array}{l}-0.4711 \\
(1.62)\end{array}$ & $\begin{array}{l}-0.3789 \\
(1.20)\end{array}$ & $\begin{array}{l}0.0251 \\
(0.21)\end{array}$ & $\begin{array}{l}0.0295 \\
(0.23)\end{array}$ & $\begin{array}{l}-0.0453 \\
(0.19)\end{array}$ & $\begin{array}{l}0.0022 \\
(0.01)\end{array}$ & $\begin{array}{l}-0.0226 \\
(0.03)\end{array}$ & $\begin{array}{l}-0.0475 \\
(0.07)\end{array}$ \\
\hline Transportation & $\begin{array}{l}0.0505 \\
(0.45)\end{array}$ & $\begin{array}{l}0.0448 \\
(0.40)\end{array}$ & $\begin{array}{l}0.1087 \\
(1.53)\end{array}$ & $\begin{array}{l}0.0979 \\
(1.27)\end{array}$ & $\begin{array}{l}-0.0474 \\
(1.20)\end{array}$ & $\begin{array}{l}-0.0107 \\
(0.26)\end{array}$ & $\begin{array}{l}-0.0214 \\
(0.39)\end{array}$ & $\begin{array}{l}-0.0325 \\
(0.49)\end{array}$ & $\begin{array}{l}-0.0049 \\
(0.03)\end{array}$ & $\begin{array}{l}-0.0022 \\
(0.02)\end{array}$ \\
\hline Wholesale trade & $\begin{array}{l}-0.1189 \\
(1.06)\end{array}$ & $\begin{array}{l}-0.1473 \\
(1.38)\end{array}$ & $\begin{array}{l}0.1988 \\
(2.17)^{* *}\end{array}$ & $\begin{array}{l}0.2004 \\
(2.02)^{* *}\end{array}$ & $\begin{array}{l}0.0111 \\
(0.26)\end{array}$ & $\begin{array}{l}0.0238 \\
(0.52)\end{array}$ & $\begin{array}{l}0.0512 \\
(0.81)\end{array}$ & $\begin{array}{l}0.0139 \\
(0.18)\end{array}$ & $\begin{array}{l}-0.2369 \\
(0.74)\end{array}$ & $\begin{array}{l}-0.2399 \\
(0.85)\end{array}$ \\
\hline Poverty & $\begin{array}{l}-0.0414 \\
(1.67)\end{array}$ & $\begin{array}{l}-0.0448 \\
(1.84)^{* * *}\end{array}$ & $\begin{array}{l}-0.0257 \\
(1.55)\end{array}$ & $\begin{array}{l}-0.0492 \\
(2.99)^{*}\end{array}$ & $\begin{array}{l}-0.0312 \\
(2.80)^{*}\end{array}$ & $\begin{array}{l}-0.0525 \\
(4.70)^{*}\end{array}$ & $\begin{array}{l}-0.0194 \\
(1.06)\end{array}$ & $\begin{array}{l}-0.0465 \\
(2.21)^{* *}\end{array}$ & $\begin{array}{l}-0.0383 \\
(0.29)\end{array}$ & $\begin{array}{l}-0.0318 \\
(0.41)\end{array}$ \\
\hline Metro area, 1970 & $\begin{array}{l}0.0052 \\
(1.63)\end{array}$ & $\begin{array}{l}0.0050 \\
(1.57)\end{array}$ & $\begin{array}{l}0.0035 \\
(2.93)^{*}\end{array}$ & $\begin{array}{l}0.0038 \\
(2.95)^{*}\end{array}$ & $\begin{array}{l}0.0012 \\
(1.51)\end{array}$ & $\begin{array}{l}0.0017 \\
(1.95)^{* *}\end{array}$ & $\begin{array}{l}0.0010 \\
(0.43)\end{array}$ & $\begin{array}{l}-0.0000 \\
(0.01)\end{array}$ & $\begin{array}{l}0.0019 \\
(0.66)\end{array}$ & $\begin{array}{l}0.0018 \\
(0.80)\end{array}$ \\
\hline $\begin{array}{l}\mathrm{R}^{2} \\
\text { Adjusted } \mathrm{R}^{2} \\
\text { \# Observations }\end{array}$ & $\begin{array}{l}0.83 \\
0.65 \\
66\end{array}$ & $\begin{array}{l}0.87 \\
0.74 \\
66\end{array}$ & $\begin{array}{l}97 \\
0.68 \\
0.51\end{array}$ & $\begin{array}{l}97 \\
0.88 \\
0.82\end{array}$ & $\begin{array}{l}254 \\
0.53 \\
0.46\end{array}$ & $\begin{array}{l}254 \\
0.71 \\
0.66\end{array}$ & $\begin{array}{l}84 \\
0.62 \\
0.34\end{array}$ & $\begin{array}{l}84 \\
0.83 \\
0.72\end{array}$ & $\begin{array}{l}39 \\
0.96 \\
0.66\end{array}$ & $\begin{array}{l}39 \\
0.96 \\
0.76\end{array}$ \\
\hline
\end{tabular}

${ }^{18}$ All RHS variables are initial values from 1970. 


\begin{tabular}{|c|c|c|c|c|}
\hline$\underline{\text { RHS Variables }}^{19}$ & $\underline{\text { OLS }}$ & $\underline{2 S L S}$ & $\underline{\text { OLS }}$ & $\underline{2 S L S}$ \\
\hline Constant & $\begin{array}{l}-0.0132 \\
(0.07)\end{array}$ & $\begin{array}{l}0.1587 \\
(0.65)\end{array}$ & $\begin{array}{l}0.2621 \\
(1.99)^{* * *}\end{array}$ & $\begin{array}{l}0.3286 \\
(3.28)^{*}\end{array}$ \\
\hline $\begin{array}{l}\text { Log } 1970 \text { per capita } \\
\text { income }^{20}\end{array}$ & $\begin{array}{l}0.0043 \\
(0.43)\end{array}$ & $\begin{array}{l}-0.0336 \\
(15.49)^{*}\end{array}$ & $\begin{array}{l}-0.0191 \\
(3.08)^{*}\end{array}$ & $\begin{array}{l}-0.0240 \\
(6.83)^{*}\end{array}$ \\
\hline Age: $5-13$ years & $\begin{array}{l}0.0763 \\
(0.29)\end{array}$ & $\begin{array}{l}0.0178 \\
(0.05)\end{array}$ & $\begin{array}{l}-0.1476 \\
(1.09)\end{array}$ & $\begin{array}{l}-0.1801 \\
(1.40)\end{array}$ \\
\hline Age: $14-17$ years & $\begin{array}{l}0.1165 \\
(0.71)\end{array}$ & $\begin{array}{l}0.0999 \\
(0.48)\end{array}$ & $\begin{array}{l}-0.0529 \\
(0.37)\end{array}$ & $\begin{array}{l}-0.1002 \\
(078)\end{array}$ \\
\hline Age: $18-64$ years & $\begin{array}{l}0.0115 \\
(0.07)\end{array}$ & $\begin{array}{l}0.0185 \\
(0.09)\end{array}$ & $\begin{array}{l}-0.1169 \\
(1.12)\end{array}$ & $\begin{array}{l}-0.1455 \\
(1.50)\end{array}$ \\
\hline Age: $65+$ & $\begin{array}{l}0.0152 \\
(0.09)\end{array}$ & $\begin{array}{l}-0.0558 \\
(0.25)\end{array}$ & $\begin{array}{l}-0.1883 \\
(1.86)^{* * *}\end{array}$ & $\begin{array}{l}-0.2164 \\
(2.30)^{* *}\end{array}$ \\
\hline Blacks & $\begin{array}{l}-0.0391 \\
(1.46)\end{array}$ & $\begin{array}{l}-0.0428 \\
(1.26)\end{array}$ & $\begin{array}{l}-0.0286 \\
(0.41)\end{array}$ & $\begin{array}{l}-0.0274 \\
(0.39)\end{array}$ \\
\hline Hispanic & $\begin{array}{l}0.0315 \\
(0.10)\end{array}$ & $\begin{array}{l}-0.1564 \\
(0.39)\end{array}$ & $\begin{array}{l}-0.0318 \\
(0.27)\end{array}$ & $\begin{array}{l}-0.0232 \\
(0.20)\end{array}$ \\
\hline Education: 9-11 years & $\begin{array}{l}0.0072 \\
(0.15)\end{array}$ & $\begin{array}{l}0.0470 \\
(0.81)\end{array}$ & $\begin{array}{l}-0.0313 \\
(1.07)\end{array}$ & $\begin{array}{l}-0.0273 \\
(0.95)\end{array}$ \\
\hline Education: H.S. diploma & $\begin{array}{l}-0.0774 \\
(2.04)^{* * *}\end{array}$ & $\begin{array}{l}-0.0223 \\
(0.50)\end{array}$ & $\begin{array}{l}-0.0311 \\
(1.78)^{* * *}\end{array}$ & $\begin{array}{l}-0.0268 \\
(1.62)\end{array}$ \\
\hline Education: Some college & $\begin{array}{l}0.0197 \\
(0.27)\end{array}$ & $\begin{array}{l}-0.0134 \\
(0.15)\end{array}$ & $\begin{array}{l}0.0129 \\
(0.37)\end{array}$ & $\begin{array}{l}0.0229 \\
(0.71)\end{array}$ \\
\hline Education: Bachelor + & $\begin{array}{l}-0.0005 \\
(0.01)\end{array}$ & $\begin{array}{l}0.1089 \\
(0.98)\end{array}$ & $\begin{array}{l}0.0767 \\
(1.86)^{* * *}\end{array}$ & $\begin{array}{l}0.0923 \\
(2.57)^{* *}\end{array}$ \\
\hline Housing & $\begin{array}{l}0.0000 \\
(0.14)\end{array}$ & $\begin{array}{l}0.0000 \\
(1.28)\end{array}$ & $\begin{array}{l}-0.0000 \\
(0.46)\end{array}$ & $\begin{array}{l}-0.0000 \\
(0.35)\end{array}$ \\
\hline $\begin{array}{l}\text { Federal government } \\
\text { employment }\end{array}$ & $\begin{array}{l}0.0606 \\
(1.06)\end{array}$ & $\begin{array}{l}0.0862 \\
(1.20)\end{array}$ & $\begin{array}{l}0.0121 \\
(0.36)\end{array}$ & $\begin{array}{l}0.0147 \\
(0.45)\end{array}$ \\
\hline $\begin{array}{l}\text { State government } \\
\text { employment }\end{array}$ & $\begin{array}{l}0.0128 \\
(0.46)\end{array}$ & $\begin{array}{l}0.0147 \\
(0.41)\end{array}$ & $\begin{array}{l}-0.0238 \\
(0.76)\end{array}$ & $\begin{array}{l}-0.0208 \\
(0.68)\end{array}$ \\
\hline $\begin{array}{l}\text { Local government } \\
\text { employment }\end{array}$ & $\begin{array}{l}-0.0773 \\
(1.18)\end{array}$ & $\begin{array}{l}-0.0250 \\
(0.31)\end{array}$ & $\begin{array}{l}0.0438 \\
(1.26)\end{array}$ & $\begin{array}{l}0.0459 \\
(1.33)\end{array}$ \\
\hline Self-employment & $\begin{array}{l}0.0245 \\
(0.36)\end{array}$ & $\begin{array}{l}-0.0084 \\
(0.10)\end{array}$ & $\begin{array}{l}0.0004 \\
(0.02)\end{array}$ & $\begin{array}{l}0.0022 \\
(0.09)\end{array}$ \\
\hline Agriculture & $\begin{array}{l}-0.0106 \\
(0.09)\end{array}$ & $\begin{array}{l}0.1886 \\
(1.38)\end{array}$ & $\begin{array}{l}0.0321 \\
(0.55)\end{array}$ & $\begin{array}{l}0.0401 \\
(0.70)\end{array}$ \\
\hline Communications & $\begin{array}{l}0.0269 \\
(0.25)\end{array}$ & $\begin{array}{l}0.1785 \\
(1.41)\end{array}$ & $\begin{array}{l}0.1230 \\
(1.21)\end{array}$ & $\begin{array}{l}0.1164 \\
(1.15)\end{array}$ \\
\hline Construction & $\begin{array}{l}-0.0309 \\
(0.32)\end{array}$ & $\begin{array}{l}0.1389 \\
(1.26)\end{array}$ & $\begin{array}{l}0.0912 \\
(1.62)\end{array}$ & $\begin{array}{l}0.0912 \\
(1.63)\end{array}$ \\
\hline $\begin{array}{l}\text { Finance, insurance } \\
\& \text { real estate }\end{array}$ & $\begin{array}{l}0.0515 \\
(0.41)\end{array}$ & $\begin{array}{l}0.1316 \\
(0.85)\end{array}$ & $\begin{array}{l}0.0395 \\
(0.51)\end{array}$ & $\begin{array}{l}0.0355 \\
(0.47)\end{array}$ \\
\hline $\begin{array}{l}\text { Manufacturing - } \\
\text { durables }\end{array}$ & $\begin{array}{l}-0.0374 \\
(0.38)\end{array}$ & $\begin{array}{l}0.1254 \\
(1.13)\end{array}$ & $\begin{array}{l}0.0570 \\
(1.00)\end{array}$ & $\begin{array}{l}0.0614 \\
(1.09)\end{array}$ \\
\hline
\end{tabular}

19 All RHS variables are initial values from 1970.

${ }^{20}$ All dollar values are in real 1992 dollars. 
Referee Appendix Table 7: Entire United States

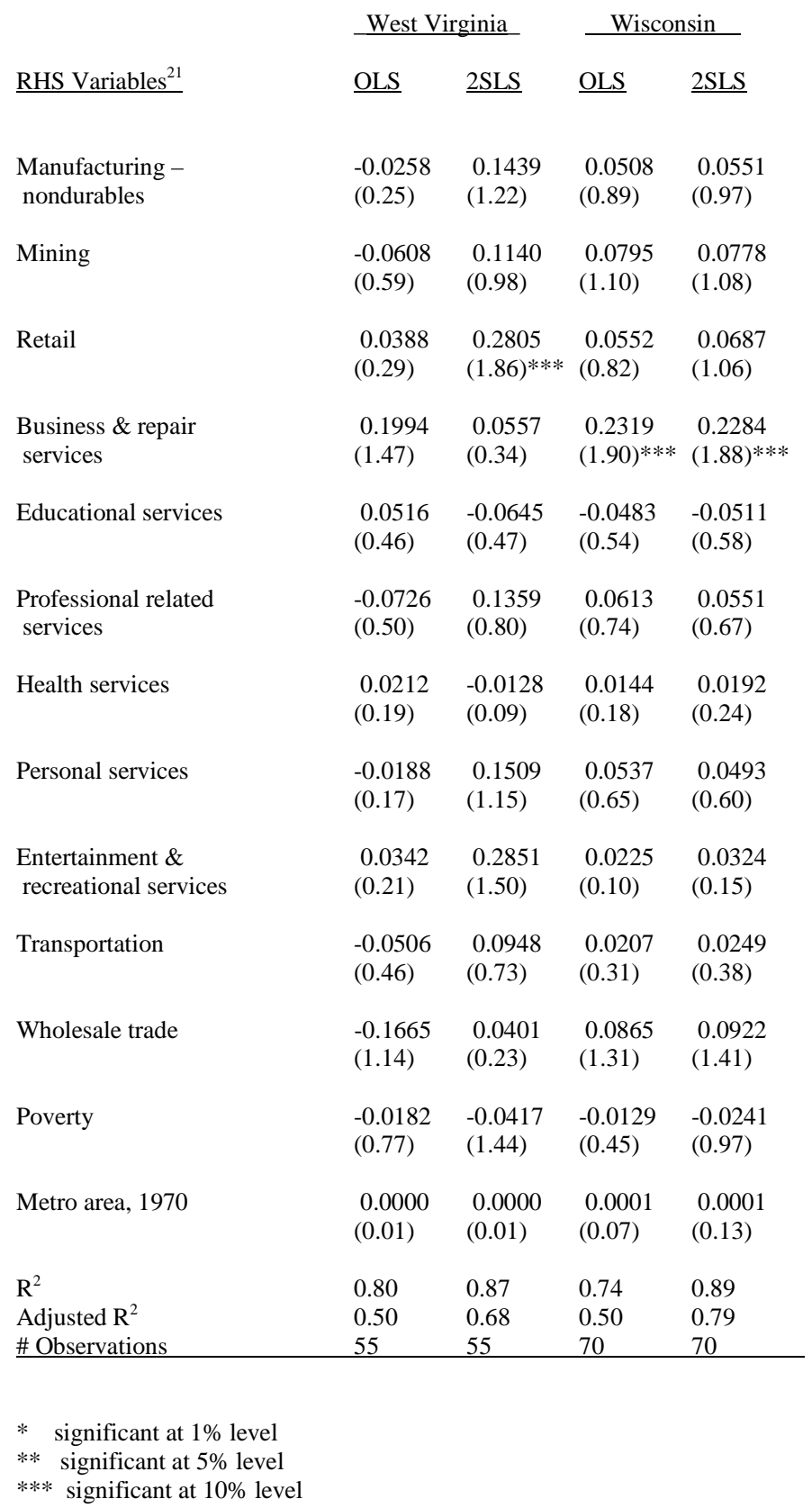

${ }^{21}$ All RHS variables are initial values from 1970. 


\section{Bar-Ilan University \\ Department of Economics \\ WORKING PAPERS}

1-01 The Optimal Size for a Minority

Hillel Rapoport and Avi Weiss, January 2001.

2-01 An Application of a Switching Regimes Regression to the Study

of Urban Structure

Gershon Alperovich and Joseph Deutsch, January 2001.

3-01 The Kuznets Curve and the Impact of Various Income Sources on the Link Between Inequality and Development

Joseph Deutsch and Jacques Silber, February 2001.

4-01 International Asset Allocation: A New Perspective

Abraham Lioui and Patrice Poncet, February 2001.

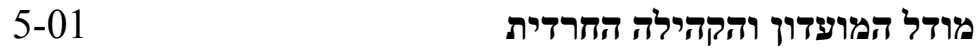

יעקב רוזנברג, פברואר 2001.

6-01 Multi-Generation Model of Immigrant Earnings: Theory and Application

Gil S. Epstein and Tikva Lecker, February 2001.

7-01 Shattered Rails, Ruined Credit: Financial Fragility and Railroad Operations in the Great Depression

Daniel A.Schiffman, February 2001.

8-01 Cooperation and Competition in a Duopoly R\&D Market

Damiano Bruno Silipo and Avi Weiss, March 2001.

9-01 A Theory of Immigration Amnesties

Gil S. Epstein and Avi Weiss, April 2001.

10-01 Dynamic Asset Pricing With Non-Redundant Forwards

Abraham Lioui and Patrice Poncet, May 2001.

Electronic versions of the papers are available at

http://www.biu.ac.il/soc/ec/wp/working_papers.html 
11-01 Macroeconomic and Labor Market Impact of Russian Immigration in Israel

Sarit Cohen and Chang-Tai Hsieh, May 2001.

12-01 Network Topology and the Efficiency of Equilibrium Igal Milchtaich, June 2001.

13-01 General Equilibrium Pricing of Trading Strategy Risk Abraham Lioui and Patrice Poncet, July 2001.

14-01 Social Conformity and Child Labor

Shirit Katav-Herz, July 2001.

15-01 Determinants of Railroad Capital Structure, 1830-1885

Daniel A. Schiffman, July 2001.

16-01 Political-Legal Institutions and the Railroad Financing Mix, 1885-1929 Daniel A. Schiffman, September 2001.

17-01 Macroeconomic Instability, Migration, and the Option Value of Education Eliakim Katz and Hillel Rapoport, October 2001.

18-01 Property Rights, Theft, and Efficiency: The Biblical Waiver of Fines in the Case of Confessed Theft

Eliakim Katz and Jacob Rosenberg, November 2001.

19-01 Ethnic Discrimination and the Migration of Skilled Labor

Frédéric Docquier and Hillel Rapoport, December 2001.

1-02 Can Vocational Education Improve the Wages of Minorities and Disadvantaged Groups? The Case of Israel

Shoshana Neuman and Adrian Ziderman, February 2002.

2-02 What Can the Price Gap between Branded and Private Label Products Tell Us about Markups?

Robert Barsky, Mark Bergen, Shantanu Dutta, and Daniel Levy, March 2002.

3-02 Holiday Price Rigidity and Cost of Price Adjustment

Daniel Levy, Georg Müller, Shantanu Dutta, and Mark Bergen, March 2002.

4-02 Computation of Completely Mixed Equilibrium Payoffs

Igal Milchtaich, March 2002. 
5-02 Coordination and Critical Mass in a Network Market An Experimental Evaluation

Amir Etziony and Avi Weiss, March 2002.

6-02 Inviting Competition to Achieve Critical Mass

Amir Etziony and Avi Weiss, April 2002.

7-02 Credibility, Pre-Production and Inviting Competition in a Network Market

Amir Etziony and Avi Weiss, April 2002.

8-02 Brain Drain and LDCs' Growth: Winners and Losers

Michel Beine, Fréderic Docquier, and Hillel Rapoport, April 2002.

9-02 Heterogeneity in Price Rigidity: Evidence from a Case Study Using Micro-Level Data

Daniel Levy, Shantanu Dutta, and Mark Bergen, April 2002.

10-02 Price Flexibility in Channels of Distribution: Evidence from Scanner Data Shantanu Dutta, Mark Bergen, and Daniel Levy, April 2002.

11-02 Acquired Cooperation in Finite-Horizon Dynamic Games Igal Milchtaich and Avi Weiss, April 2002.

12-02 Cointegration in Frequency Domain

Daniel Levy, May 2002.

13-02 Which Voting Rules Elicit Informative Voting?

Ruth Ben-Yashar and Igal Milchtaich, May 2002.

14-02 Fertility, Non-Altruism and Economic Growth:

Industrialization in the Nineteenth Century

Elise S. Brezis, October 2002.

15-02 Changes in the Recruitment and Education of the Power Elites in Twentieth Century Western Democracies

Elise S. Brezis and François Crouzet, November 2002.

16-02 On the Typical Spectral Shape of an Economic Variable Daniel Levy and Hashem Dezhbakhsh, December 2002.

17-02 International Evidence on Output Fluctuation and Shock Persistence Daniel Levy and Hashem Dezhbakhsh, December 2002. 
1-03 Topological Conditions for Uniqueness of Equilibrium in Networks Igal Milchtaich, March 2003.

2-03 Is the Feldstein-Horioka Puzzle Really a Puzzle?

Daniel Levy, June 2003.

3-03 Growth and Convergence across the US: Evidence from County-Level Data

Matthew Higgins, Daniel Levy, and Andrew Young, June 2003.

4-03 Economic Growth and Endogenous Intergenerational Altruism Hillel Rapoport and Jean-Pierre Vidal, June 2003.

5-03 Remittances and Inequality: A Dynamic Migration Model Frédéric Docquier and Hillel Rapoport, June 2003.

6-03 Sigma Convergence Versus Beta Convergence: Evidence from U.S. County-Level Data

Andrew T. Young, Matthew J. Higgins, and Daniel Levy, September 2003.

7-03 Managerial and Customer Costs of Price Adjustment: Direct Evidence from Industrial Markets

Mark J. Zbaracki, Mark Ritson, Daniel Levy, Shantanu Dutta, and Mark Bergen, September 2003.

8-03 First and Second Best Voting Rules in Committees

Ruth Ben-Yashar and Igal Milchtaich, October 2003.

9-03 Shattering the Myth of Costless Price Changes: Emerging Perspectives on Dynamic Pricing

Mark Bergen, Shantanu Dutta, Daniel Levy, Mark Ritson, and Mark J. Zbaracki, November 2003.

1-04 Heterogeneity in Convergence Rates and Income Determination across U.S. States: Evidence from County-Level Data

Andrew T. Young, Matthew J. Higgins, and Daniel Levy, January 2004. 